IZA DP No. 8854

How Many Educated Workers for Your Economy? European Targets, Optimal Public Spending, and Labor Market Impact

Isabelle Lebon

Thérèse Rebière

February 2015 


\title{
How Many Educated Workers for Your Economy? European Targets, Optimal Public Spending, and Labor Market Impact
}

\author{
Isabelle Lebon \\ CREM-CNRS, University of Caen \\ and TEPP-CNRS \\ Thérèse Rebière \\ LIRSA-CNAM \\ and IZA
}

Discussion Paper No. 8854

February 2015

IZA

P.O. Box 7240

53072 Bonn

Germany

Phone: +49-228-3894-0

Fax: +49-228-3894-180

E-mail: iza@iza.org

\begin{abstract}
Any opinions expressed here are those of the author(s) and not those of IZA. Research published in this series may include views on policy, but the institute itself takes no institutional policy positions. The IZA research network is committed to the IZA Guiding Principles of Research Integrity.

The Institute for the Study of Labor (IZA) in Bonn is a local and virtual international research center and a place of communication between science, politics and business. IZA is an independent nonprofit organization supported by Deutsche Post Foundation. The center is associated with the University of Bonn and offers a stimulating research environment through its international network, workshops and conferences, data service, project support, research visits and doctoral program. IZA engages in (i) original and internationally competitive research in all fields of labor economics, (ii) development of policy concepts, and (iii) dissemination of research results and concepts to the interested public.
\end{abstract}

IZA Discussion Papers often represent preliminary work and are circulated to encourage discussion. Citation of such a paper should account for its provisional character. A revised version may be available directly from the author. 
IZA Discussion Paper No. 8854

February 2015

\section{ABSTRACT}

\section{How Many Educated Workers for Your Economy? European Targets, Optimal Public Spending, and Labor Market Impact ${ }^{1}$}

This paper studies optimal taxation schemes for education in a search-matching model where the labor market is divided between a high-skill and a low-skill sector. Two public policy targets - maximizing the global employment level and optimizing the social surplus are studied according to three different public taxation strategies. We calibrate our model using evidence from fourteen European countries, and compare our results with the target from the Europe 2020 Agenda for achievement in higher education. We show that, with current labor market characteristics, the target set by governments seems compatible with the social surplus maximization objective in some countries, while being too high for other countries. For all countries, maximizing employment would imply higher educational spending than that required for the social surplus to reach its maximum.

JEL Classification: $\quad H 21, H 52, \mathrm{~J} 21, \mathrm{~J} 64$

Keywords: educational policy, job search, matching model, optimal taxation

Corresponding author:

Thérèse Rebière

LIRSA-CNAM

Department of Economics

40 rue des Jeûneurs

Case 1D2P30

75002 Paris

France

E-mail: therese.rebiere@cnam.fr

\footnotetext{
${ }^{1}$ We want to thank Mathilde Guergoat-Larivière as well as Riccardo Magnani for their technical help, participants of the SaM Annual Conference 2014, and participants of the Internal Seminar of the University of La Réunion, France, 2014.
} 


\section{Introduction}

In most European countries the educational system receives significant public subsidy. The high level of funding provided by every government underlines the importance of investing in high-quality education. Public spending for student support in tertiary education is distributed through different schemes: direct study grants for students; tax relief directly linked to participation in higher education; publicly subsidized and guaranteed loans; subsidized accommodation, meals or transport for students; and sometimes family allowances related to participation in higher education. Public funding of this kind has to be financed through a taxation. The question is therefore: how much effort are governments prepared to make to exert sufficient fiscal pressure to achieve the objectives of their education polices? Recently Spain and the UK allowed their universities to increase tuition fees, a change brought by the need to reduce government spending. Reaction to these changes demonstrated quite how much the Spanish and the British are attached to publicly-funded education.

Over the past few decades European policy-makers have often drawn attention to the need to improve the educational level of the citizenry, the common view being that an increase in the number of educated individuals would benefit the economy. Following the Bologna Process of 1999 and the first Lisbon strategy, the results of which changes were anticipated to take ten years to mature, education became a primary policy area for European countries (Keeling 2006). Higher education was modernized by imposing a degree of standardization across the European education system, and also by improving the mobility of students within the EU. More recently, the European Commission has restated the importance of education and training, both in facilitating entry into working life, and progression with it; this is thought to be a crucial issue for Europe today, and also in the future (European Commission 2013). The new Lisbon strategy 2020, also referred to as the Europe 2020 Agenda, does indeed seek to promote efficient educational investment as critical to the achievement of knowledge-based growth and jobs. Apart from four strategic objectives ${ }^{2}$, the Lisbon strategy for education and training sets five quantitative performance targets to be reached by 2020, one of them being that at least $40 \%$ of the 30-34 year-old age group should have completed a higher-education level, undergraduate degree or higher (Official Journal of the European Union, 2009). This European average was linked to proposed individual targets for each of the 27 member sates $^{3}$. The highest target was set for Ireland, to achieve a level of $60 \%$ of 30-34 year-olds having completed tertiary education, the Irish level for 2002 being $32 \%$, and $51.1 \%$ for 2012. Italy set the lowest 2020 target at $26 \%$, the level actually having been achieved being only $13.1 \%$ in 2002 and $21.7 \%$ in 2012 .

\footnotetext{
${ }^{2}$ Making lifelong learning and mobility a reality; improving the quality and efficiency of education and training; promoting equity, social cohesion and active citizenship; enhancing creativity and innovation, including entrepreneurship, at all levels of education and training.

${ }^{3}$ see the Eurostat website at http://epp.eurostat.ec.europa.eu/tgm/table.do?tab=table\&init= 1\&plugin=1\&language $=$ en\&pcode=t2020_41, last accessed January 2nd, 2015.
} 
In order to achieve these five targets, member states committed significant public financial support to the educational system, investing in educational infrastructure, funding specific educational programs, and providing financial support for students. Altogether, total expenditure and educational budgets remained stable between 2007 and 2010, or in some countries increased. In 2010 the share of total public expenditure allocated to education in general was for instance $8.9 \%$ in Italy and $9 \%$ in Ireland (see European Commission 2013). In the economic literature many articles concentrate on optimal public spending in the context of multiple criteria. Kaganovich and Zilcha (1999), and Sylwester (2002) concentrated respectively on the impact of public spending on growth and on inequality, while Zhang (1996) dealth with both issues. Benabou (2002), and Siew and Zhang (2013) studied the efficiency of educational expenditure. The former emphasizes that educational expenditures compensate for credit market imperfections, while the latter consider these expenditures in a framework where a trade-off occurs between fertility and human capital accumulation. Blankenau and Simpson (2004) pointed out that, for a given level of public spending, the type of fiscal taxation scheme introduced can affect the efficiency of educational policy. However our review of the economic literature search identified no research-based evidence that can be used to support or reject the Lisbon higher education criteria. Our analysis therefore has in view current European Union policy. Since employment is a leading issue in European countries, and especially for young workers, the nature of the connection between education and employment cannot be overlooked. Here one issue is the optimal tax rate corresponding to desired levels of public spending on higher education that a government should impose in order to maximize the level of employment. Alternatively, one could treat social well-being as the most important criteria. The target would then be the maximization of the social surplus.

We consider the previous targets in a specific matching model with a dual labor market where job search is perfectly directed in each sector, as in Acemoglu (2001). In a search and matching model in which workers have a finite life expectancy (Moen and Rosén 2004, Gavrel et al. 2010), educated workers direct their search towards the high-skill sector, while uneducated workers search in the low-skill sector only. The "educated" status of workers is defined as individuals whose educational attainment is higher than that of a high-school diploma, hence the individual possesses at least the lowest level of tertiary education qualification. We consider three different taxation schemes. First of all, a very specific taxation scheme in which the tax, the product of which is used to finance higher education only, is imposed in high-skill firms on the productivity gap between high-skill jobs and low-skill jobs, the high-skill sector being more productive than its counterpart. In the framework we examine the analytical solution for the highest possible share of educated workers, and then derive the optimal tax rate for the two targets under consideration: the maximization of the employment level, and the optimization of the social surplus. Secondly, the same procedure is followed for more usual taxation schemes: the funding of the public education system by a tax on profits, and also by a tax on wages. We then calibrate our model using evidence from 14 European member states for 2010. We analyze the rationality of each target, and compare our results with the European 
target given to each country as part of the Lisbon strategy 2020.

The paper is organized as follows: Section 2 outlines the analytical framework, presents three different taxation schemes for public education, and proposes the analytical solution for the equilibrium value of the highest possible share of educated workers for one of the three taxation scenarios. We define possible Government targets, and give the optimal tax rate that result from them for the same taxation scheme in section 3. Section 4 presents a calibration of the model using evidence from 14 European countries for all taxation scenarios. Finally, section 5 makes some concluding comments.

\section{The model: two labor market sectors and a public educational system}

The model describes a labor market with two types of jobs constituting the two sectors of this economy: (1) high-skill jobs with high productivity, held only by educated workers; (2) low-skill jobs with lower productivity, held only by uneducated workers. Workers are considered to be educated when they succeed in obtaining their first higher education degree (tertiary: university or of similar level), while workers with a high-school degree or less are considered to be uneducated. The educational system is public, so that the share of educated workers depends, for each age group, on Government investment in education. The cost of education is assumed to be supported by the tax revenue which can be levied according to different tax bases.

\subsection{An economy with two sectors and perfect directed job-search}

Firms are infinitely-lived whereas workers have a finite life expectancy of $1 / \mathrm{m}$. Time is continuous and parameter $m$ measures the workers' labor market exit rate. Workers who leave the market are replaced with newcomers, a share $\alpha$ of which is educated. The measure of the total labor-force is constant and normalized to one. All agents are riskneutral and discount future payoffs at rate $r(r \geq 0)$.

Sector 1 consists of firms each having a single high-skill job producing output $y_{1}$. These firms need educated workers in order to be productive. Sector 2 consists of firms each having a single low-skill job producing output $y_{2}$. These firms produce with uneducated workers. We have $y_{1}>y_{2}$.

Job search is perfectly directed, hence educated unemployed workers, denoted as $u_{1}$, apply only for high-skill vacancies. Educated unemployed workers are of two types: educated newcomers, and educated workers who separated from their high-skill jobs at rate $s_{1}$. The same apply to uneducated unemployed workers, denoted $u_{2}$. They apply for low-skill vacancies only, and are of two types: uneducated newcomers, and uneducated workers who separated from their low-skill jobs at rate $s_{2}$. When hiring a worker, firms are indifferent between newcomers and workers that separated from their previous jobs. 
Thus all educated unemployed workers have the same probability of obtaining a high-skill job as a newcomer. The same applies to uneducated unemployed workers.

Job creation results from the usual assumption of free entry in both sectors. Market frictions in sector- $i$, with $i=1,2$, are summarized in a constant-returns matching function that defines the arrival rate of workers to job vacancies $q_{i}\left(\theta_{i}\right)$ with $q_{i}^{\prime}\left(\theta_{i}\right)<0$. The arrival rate of job offers to searching workers is $p_{i}=\theta_{i} q_{i}$ with $p_{i}^{\prime}\left(\theta_{i}\right)>0$ where $\theta_{i}\left(\theta_{i}=\frac{v_{i}}{u_{i}}\right.$, with $v_{i}$ the share of vacancies in sector $i$ ) is the sector tightness. The higher the tightness $\theta_{i}$, the shorter the unemployment duration for a worker but the longer the job-vacancy duration for a firm. The function $p_{i}\left(\theta_{i}\right)$ has an elasticity $\left(1-\eta_{i}\right)\left(\right.$ where $\left.0<\eta_{i}<1\right)$.

\subsection{Educated workers and the financing of the educational system}

\subsubsection{Educational cost}

Newcomers have obtained their degree and are therefore considered educated in proportion $\alpha$. A share $(1-\alpha)$ of newcomers remains uneducated. Assuming that the share of educated workers is the same for each age group, $\alpha$ represents the share of educated workers in the economy.

Since the educational system is public, the share of young individuals obtaining their degree is correlated with the expenditure made by government for educational purposes. We assume that the average cost of educating a young individual $(\mu)$ increases with the share of educated newcomers belonging to an age group, $\alpha$. This assumption is based on the fact that as $\alpha$ gradually increases, the uneducated individuals remaining are decreasingly receptive to education. These individuals therefore require a greater amount of financial effort from the government. The average cost of education thus depends on the shape of the function $\mu(\alpha)$ which is increasing in $\alpha\left(\mu^{\prime}>0\right)$. Notice that $\varepsilon$ is the elasticity of the average cost $\mu(\alpha)$.

Since the labor-force is normalized to 1 , there are $\alpha m$ educated newcomers, representing a total cost of education $\alpha m \mu(\alpha)$. This total cost is increasing in $\alpha$.

\subsubsection{Taxation schemes and the budget constraint for public education}

Public education can be financed through different taxation schemes. The funds could be raised from revenue on capital, that is to say from profits, or from the revenue from labor, that is to say wages. Another option would be to tax the economic agents that directly benefit from tertiary education, that is to say, taxing the productivity gap resulting from the recruitment of an educated worker. This section present these different possible scenarios, starting with the last.

\section{Scenario PG: Tax on productivity gap}

As stated before, there are two types of firm in the economy. Sector 1 firms and their educated employees are highly productive, and are thus the only firms to benefit from the educational system. We assume in this taxation scenario that they are the only firms participating in the financing of public education. The tax rate $t$ is 
imposed on the productivity increase associated with the recruitment of educated workers, that is to say, the productivity gap $\left(y_{1}-y_{2}\right)$ between a high-skill and a low-skill job. Each sector 1 job therefore pays a tax $t\left(y_{1}-y_{2}\right)$. The product of this tax is used in full as the sole financial source for spending on the public educational system.

The total revenue raised by the tax depends on the number of high-skill firms, that is to say, the number of educated employees $\left(\ell_{1}\right)$, and also on the productivity gap between high-skill and low-skill jobs.

In this scenario, the total revenue is $t\left(y_{1}-y_{2}\right) \ell_{1}$ and the budget constraint for public education can be written as:

$$
t\left(y_{1}-y_{2}\right) \ell_{1}=\alpha m \mu(\alpha)
$$

Scenario P: Tax on profits

Here the funding of public education costs is raised from the profits (output minus wages) of the firms in the two sectors. In this scenario, the total revenue is $t\left[\left(y_{1}-\right.\right.$ $\left.\left.w_{1}\right) \ell_{1}+\left(y_{2}-w_{2}\right) \ell_{2}\right]$, where $w_{i}$ is wages in sector $i$ (with $i=1,2$ ) and $\ell_{2}$ the number of uneducated employees. In this case, the budget constraint for public education is:

$$
t\left[\left(y_{1}-w_{1}\right) \ell_{1}+\left(y_{2}-w_{2}\right) \ell_{2}\right]=\alpha m \mu(\alpha)
$$

Scenario W: Tax on wages

Here workers in both sectors are the only ones financing educational policy. In this scenario, the total revenue is $t\left(w_{1} \ell_{1}+w_{2} \ell_{2}\right)$. The budget constraint for public education when tax is levied on wages in both sectors can be written as:

$$
t\left(w_{1} \ell_{1}+w_{2} \ell_{2}\right)=\alpha m \mu(\alpha)
$$

For the sake ease of exposition, the following theoretical sections present the model on the basis of the productivity-gap-taxation scenario only (scenario PG). However, equivalent equations for the two other scenarios ( $\mathrm{P}$ and $\mathrm{W})$, on which the calibration section of the paper is partly based, are presented in an unpublished appendix available from the authors upon request ${ }^{4}$.

\subsection{High-skill and low-skill job creation}

The asset value of a vacancy is denoted $V_{i}$. Maintaining a vacant job requires that the firm pays a cost $c_{i}$, which gives the firm the opportunity of finding a worker at rate $q_{i}$. When the job is filled by a worker, its asset value becomes $J_{i}$ (for $i=1,2$ ).

\footnotetext{
${ }^{4}$ We choose to favor the presentation of the "tax on the productivity gap" scenario for two main reasons: it is the only fully tractable scenario, and it has interesting calibration results.
} 


$$
r V_{i}=-c_{i}+q_{i}\left(J_{i}-V_{i}\right)
$$

The number of high-skill jobs depends on the number of educated workers and on the profitability of a high-skill firm whose job is filled. The higher the public expenditure on education, the higher the number of educated workers searching for a high-skill job. This increases high-skill job creation. However, a rise in a tax $t$ used to finance education reduces the profitability of high-skill jobs, and this lowers high-skill job creation. The impact of the tax on high-skill job creation is twofold. This phenomenon is observed only in sector 1 , since the tax does not have any impact upon low-skill job creation.

The profitability of a firm also depends on the wages, $w_{i}$, paid to its unique employee. They are negotiated according to a Nash bargaining game where $\beta$ is the worker's bargaining power and $(1-\beta)$ that of the firm. When a worker and a firm meet and agree to form a match, the private surplus $S_{i}$ of this match is shared between the worker and the firm according to their respective bargaining power.

The asset value $J_{i}$ also takes into account the average duration during which the job remains productive. This duration depends on the exogenous destruction rate $s_{i}$, and on the permanent exit rate of the worker from the labor market, $m$.

For a filled job, the asset values are given by the following Bellman equations:

$$
\begin{gathered}
r J_{1}=\left[\left(y_{1}-y_{2}\right)(1-t)+y_{2}\right]-w_{1}-\left(m+s_{1}\right)\left(J_{1}-V_{1}\right) \\
r J_{2}=y_{2}-w_{2}-\left(m+s_{2}\right)\left(J_{2}-V_{2}\right)
\end{gathered}
$$

Job creation results from the usual assumption of free entry in each sector, so that in a steady-state $V_{i}=0$. We deduce from equation (4):

$$
J_{i}=\frac{c_{i}}{q_{i}}
$$

Because of free-entry, we deduce, for sector 1 , from equations (4) for $i=1$, and (5):

$$
\left(r+m+s_{1}\right) J_{1}=\left[\left(y_{1}-y_{2}\right)(1-t)+y_{2}\right]-w_{1}
$$

And for sector 2, we deduce from the equations (4) for $i=2$, and (6):

$$
\left(r+m+s_{2}\right) J_{2}=y_{2}-w_{1}
$$

On the workers' side, the asset value of an employee, $W_{i}$, and that of an unemployed worker, $U_{i}$ are given by:

$$
\begin{gathered}
r W_{i}=w_{i}-s_{i}\left(W_{i}-U_{i}\right)-m W_{i} \\
r U_{i}=d+p_{i}\left(W_{i}-U_{i}\right)-m U_{i}=d+\beta p_{i} S_{i}-m U_{i}
\end{gathered}
$$

where $d$ is the value for non-market activities of an unemployed worker. From equations (10) and (11), the workers' surplus can be written as:

$$
\left(r+m+s_{i}\right)\left(W_{i}-U_{i}\right)=w_{i}-d-\beta p_{i} S_{i}
$$


In sector 1 , equations (8) and (12), for $i=1$, give the surplus of the match between an educated worker and a high-skill firm:

$$
\left(r+m+s_{1}\right)\left(J_{1}+W_{1}-U_{1}\right)=\left(r+m+s_{1}\right) S_{1}=\left(y_{1}-y_{2}\right)(1-t)+y_{2}-d-\beta p_{1} S_{1}
$$

Knowing that the firm has a share $(1-\beta)$ of the match surplus, we have: $J_{1}=(1-\beta) S_{1}$. Combining equations (7), for $i=1$, and (13) gives the equilibrium equation for job creation in sector 1 :

$$
\frac{c_{1}}{q_{1}}=(1-\beta) \frac{\left(y_{1}-y_{2}\right)(1-t)+y_{2}-d}{\left(r+m+s_{1}+\beta p_{1}\right)}
$$

Tightness $\theta_{1}$ decreases with the tax $t$ applied to the productivity gap between the two sectors.

In sector 2 , equations (9) and (12) for $i=2$ gives the surplus of the match between an educated worker and a high-skill firm:

$$
\left(r+m+s_{2}\right)\left(J_{2}+W_{2}-U_{2}\right)=\left(r+m+s_{2}\right) S_{2}=y_{2}-d
$$

Knowing that the firm has also a share $(1-\beta)$ of the match surplus, we have: $J_{2}=$ $(1-\beta) S_{2}$. Combining equations (7) for $i=2$, and (15) gives the equilibrium equation for job creation in sector 2 :

$$
\frac{c_{2}}{q_{2}}=(1-\beta) \frac{y_{2}-d}{\left(r+m+s_{2}+\beta p_{2}\right)}
$$

This sector 2 equilibrium equation is standard (Pissarides 2000).

\subsection{Labor-force structure}

The labor-force structure does not depend on the taxation scenario. We assume that each age group of workers present in the labor market benefits from the same governmental educational effort. The share of educated workers, $\alpha$, is therefore homogeneous, disregarding the years of experience of workers in the labor market. Let $u_{1}$ be the pool of educated unemployed workers, $\ell_{1}$ educated workers' employment, $u_{2}$ uneducated workers' unemployment, and $\ell_{2}$ uneducated workers' employment.

In order to establish equilibrium flows of workers in each sector, we present transition frequencies for each possible state of the labor market - educated employees (or uneducated employees) who separated from their jobs and educated (or uneducated) newcomers - join the pool of educated (or uneducated) unemployed workers; educated (or uneducated) workers quit unemployment when they find a high-skill (or low-skill) job, or when they definitely quit the labor market. In equilibrium, the number of newcomers equals the number of outgoing individuals for each state of the labor market. The flows equilibrium equations are thus:

$$
\begin{gathered}
s_{1} \ell_{1}+\alpha m=\left(m+p_{1}\right) u_{1} \\
s_{2} \ell_{2}+(1-\alpha) m=\left(m+p_{2}\right) u_{2}
\end{gathered}
$$


A share $p_{1}$ (respectively $p_{2}$ ) of unemployed workers finds a job at a given point in time. This entry into employment is compensated by the exit of employees from the labor market, and by job separations. We therefore have:

$$
\begin{aligned}
& p_{1} u_{1}=\left(m+s_{1}\right) \ell_{1} \\
& p_{2} u_{2}=\left(m+s_{2}\right) \ell_{2}
\end{aligned}
$$

In a steady state, employment and unemployment levels are deduced from the flow equilibrium conditions, taking into account a labor-force normalized to 1.

$$
\begin{gathered}
u_{1}=\frac{\alpha\left(m+s_{1}\right)}{\left(m+s_{1}+p_{1}\right)} \\
\ell_{1}=\frac{\alpha p_{1}}{\left(m+s_{1}+p_{1}\right)} \\
u_{2}=\frac{(1-\alpha)\left(m+s_{2}\right)}{\left(m+s_{2}+p_{2}\right)} \\
\ell_{2}=\frac{(1-\alpha) p_{2}}{\left(m+s_{2}+p_{2}\right)}
\end{gathered}
$$

In each sector a rise in tightness reduces unemployment, thus favoring a rise in employment. A rise in the share of educated workers $\alpha$ mechanically leads to a shift of the labor-force towards the high-skill sector.

\subsection{Steady-state equilibrium}

The distribution of the labor-force provides the number of high-skill productive firms that are taxed to finance the public educational system. It therefore determines the proportion of young workers who will benefit from education. Combining equations (1) and (22) gives the budget constraint for education:

$$
t\left(y_{1}-y_{2}\right) p_{1}=\left(m+s_{1}+p_{1}\right) m \mu(\alpha)
$$

The share of educated workers $\alpha$ is an increasing function in tax $t$ and in tightness $\theta_{1}$.

Definition 1. A labor market equilibrium is a set of variables $\left(\theta_{1}^{*}, \theta_{2}^{*}, \alpha^{*}\right)$ defined by equations (14), (16), and (25) as a function of the tax rate $t$ whose value is decided by the decision-maker. Other variables are deduced from those given previously.

Note that $\theta_{2}$, determined by (16), is independent of $t$ and of $\theta_{1}$. Its value is not affected by a change in educational policy. However, the number of uneducated workers directly depends on a policy of this kind.

Variables $\theta_{1}^{*}$ and $\alpha^{*}$ are recursively determined. Equation (14) gives the tightness of the high-skill sector as a function of $t$. The share of educated workers is then deduced from equation (25) which depends on $\theta_{1}^{*}$ and $t$. 


\subsection{Highest possible share of educated workers}

As we shall see in the empirical part of our work, an increase in the the share of educated workers amongst young workers is often presented as a quantitative target by decision makers when making public speeches. Some justification has to be made that this is a reasonable (or rational) public policy choice. Whether the public policy targets set by governments are achievable is something that needs to be examined. This section focuses on this question by establishing the highest possible share of educated workers $\alpha$ that an economy can achieve. This proportion must be defined theoretically to ensure that quantitative targets remain lower than, or at the most equal to, this share. Moreover, as will become apparent in the following section, optimal taxation strategies can be compared with the tax rate needed to reach this highest share of educated workers. Consequently, we here establish a tax rate likely to maximize the share of educated workers for a specific financing scheme, and compare this rate with the highest tax rate possible (its upper bound).

The direct impact of tax rate $t$ on the share of educated workers $\alpha$, the tax being targeted on the productivity supplement gained from high-skill jobs, is measured by the budget constraint of the educational system (equation (25)). The indirect effect of the tax rate involves the tightness of the high-skill sector $\theta_{1}$. The value of $t$ which optimizes the share of educated workers is deduced from the following equation:

$$
\frac{d \alpha}{d t}=0 \Leftrightarrow \frac{\partial \alpha}{\partial t}+\frac{\partial \alpha}{\partial \theta_{1}} \frac{\partial \theta_{1}}{\partial t}=0
$$

Terms $\frac{\partial \alpha}{\partial t}$ and $\frac{\partial \alpha}{\partial \theta_{1}}$ are given by differentiating equation (25). The term $\frac{\partial \theta_{1}}{\partial t}$ is determined via the equation for job creation in the high-skill sector (equation (14)):

$$
\begin{gathered}
\frac{\partial \alpha}{\partial t}=\frac{\left(y_{1}-y_{2}\right) p_{1}}{\left(m+s_{1}+p_{1}\right) m \mu^{\prime}}>0 \\
\frac{\partial \alpha}{\partial \theta_{1}}=\frac{\left(1-\eta_{1}\right) p_{1}\left[t\left(y_{1}-y_{2}\right)-m \mu(\alpha)\right]}{\theta_{1}\left(m+s_{1}+p_{1}\right) m \mu^{\prime}}
\end{gathered}
$$

From equation (25), one can show that around the equilibrium we have $p_{1}\left[t\left(y_{1}-y_{2}\right)-\right.$ $m \mu(\alpha)]=\left(m+s_{1}\right) m \mu(\alpha)$. We thus have $\frac{\partial \alpha}{\partial \theta_{1}}>0$.

$$
\frac{\partial \theta_{1}}{\partial t}=\frac{-\theta_{1}(1-\beta)\left(y_{1}-y_{2}\right)}{\theta_{1}\left(1-\eta_{1}\right) \beta c_{1}+\eta_{1}(1-\beta)\left[\left(y_{1}-y_{2}\right)(1-t)+y_{2}-d\right]}<0
$$

The increase of $t$ has a negative effect on the revenues obtained through the tax. It therefore also has a negative impact on the share of educated workers $\alpha$. On the one hand, the rise of $t$ increases the withdrawal from a high-skill firm whose job is occupied. This boosts the financing of the educational system. On the other hand, the increase of $t$ reduces the number of high-skill jobs, since it reduces the profitability of high-skill firms. This leads to a reduction in the tax base, and therefore in tax revenues. 
Combining equations (26), (27), (28), and (29), leads to the determination of the optimal tax equation, where $t_{\alpha}^{*}$ is the optimal tax level:

$$
t_{\alpha}^{*}=\frac{(1-\beta)\left(1-\eta_{1}\right) m \mu(\alpha)+\left(1-\eta_{1}\right) c_{1} \beta \theta_{1}+(1-\beta) \eta_{1}\left(y_{1}-d\right)}{(1-\beta)\left(y_{1}-y_{2}\right)}
$$

The optimal tax level $t_{\alpha}^{*}$ is positive. The model makes sense so long as the net output of a high-skill job is higher than or equal to that of a low-skill job, that is to say so long as the level of the tax remains below or equal to 1 . We study the value of the optimal tax level $t_{\alpha}^{*}$ by replacing two terms in equation (30). First, we consider that, around the equilibrium, $c_{1}$ is replaced by its equation in (14). Second, $\mu(\alpha)$ is replaced by its equation in $(25) . t_{\alpha}^{*}$ can therefore be written as:

$$
\begin{aligned}
t_{\alpha}^{*}= & \frac{\left(y_{1}-d\right)}{\left(y_{1}-y_{2}\right)} \times \\
& \frac{\left(m+s_{1}+p_{1}\right)\left[\beta p_{1}+\eta_{1}\left(r+m+s_{1}\right)\right]}{\left(m+s_{1}+p_{1}\right)\left[\beta p_{1}+\eta_{1}\left(r+m+s_{1}\right)\right]+\left(1-\eta_{1}\right)\left(m+s_{1}\right)\left(r+m+s_{1}+\beta p_{1}\right)}
\end{aligned}
$$

We deduce from the previous equation that $t_{\alpha}^{*}<1$ if and only if:

$$
y_{2} \leq \frac{y_{1}\left(1-\eta_{1}\right)\left(m+s_{1}\right)\left(r+m+s_{1}+\beta p_{1}\right)+d\left(m+s_{1}+p_{1}\right)\left[\beta p_{1}+\eta_{1}\left(r+m+s_{1}\right)\right]}{\left(m+s_{1}+p_{1}\right)\left[\beta p_{1}+\eta_{1}\left(r+m+s_{1}\right)\right]+\left(1-\eta_{1}\right)\left(m+s_{1}\right)\left(r+m+s_{1}+\beta p_{1}\right)}
$$

If this condition for the relative values of $y_{1}, y_{2}$, and $d$ is not fulfilled, the policy-maker will chose the maximum value possible for $t$ under which the net output of a high-skill job equals that of a low-skill job, that is to say $\tilde{t}_{\alpha}=1 .^{5}$

\section{Government targets and optimal taxation}

The decision-maker can link its educational policy to different objectives. In this section we compare the tax rate obtained at the highest possible share of educated workers with two economic objectives that could potentially be implemented by the decision-maker: the minimization of unemployment or the maximization of global employment; and the maximization of the social surplus.

\subsection{Maximization of global employment}

The first objective that the decision-maker could implement is the optimization of total employment. Let us note $\ell$ the sum of employment in the economy $\left(\ell_{1}+\ell_{2}\right)$. One can write total employment $\ell$ as a function of $\alpha, \theta_{1}$, and $\theta_{2}$ using equations (22) and (24):

$$
\ell=\ell_{1}+\ell_{2}=\frac{\alpha p_{1}}{\left(m+s_{1}+p_{1}\right)}+\frac{(1-\alpha) p_{2}}{\left(m+s_{2}+p_{2}\right)}
$$

\footnotetext{
${ }^{5}$ The calibration performed in section 4 reveals that $\tilde{t}_{\alpha}=1$ is the limit of the PG scenario for all European countries studied. For the other scenarios, we have $t_{\alpha}^{*}<1$.
} 
The derivatives of the optimal tax rate $t_{\ell}^{*}$ that maximize global employment are given in Appendix A.1. We have:

$$
t_{\ell}^{*}=t_{\alpha}^{*}-\frac{\left(1-\eta_{1}\right)\left(m+s_{1}\right)\left(m+s_{2}+p_{2}\right) m \varepsilon \mu(\alpha)}{\left(y_{1}-y_{2}\right)\left(p_{1}\left(m+s_{2}\right)-p_{2}\left(m+s_{1}\right)\right)}
$$

We can compare the two optimal levels of the tax rate $t$ obtained at the highest share of educated workers $t_{\alpha}^{*}$ and obtained by the maximization of the global employment level $t_{\ell}^{*}$. The comparison depends on the relative value of transition rates to unemployment and employment in the two sectors:

- If $\left[p_{1}\left(m+s_{2}\right)-p_{2}\left(m+s_{1}\right)\right]>0$, we have: $t_{\ell}^{*}<t_{\alpha}^{*}$. We can show that $t_{\ell}^{*}$ remains strictly positive (see Appendix A.1).

- If $\left[p_{1}\left(m+s_{2}\right)-p_{2}\left(m+s_{1}\right)\right]<0$, we have $t_{\ell}^{*}>t_{\alpha}^{*}>0$, keeping in mind that, as mentioned previously, the tax rate cannot exceed 1.

Neither of the two cases can be theoretically ruled out. However we can decide on which case is to be retained by considering the empirical reality of the labor market: uneducated or less-skilled workers often occupy jobs which are less stable and more precarious than educated and skilled workers (inducing $s_{2}>s_{1}$ ), moreover they face greater difficulties in finding a job $\left(\right.$ i.e. $\left.\left.p_{2}<p_{1}\right)\right)$. These observations lead us to think that $\left[p_{1}\left(m+s_{2}\right)-\right.$ $\left.p_{2}\left(m+s_{1}\right)\right]$ should be positive. We can therefore consider that the tax rate maximizing the global employment level should be lower than the tax rate that maximizes the share of educated workers.

\subsection{Maximization of the social surplus}

Here the efficient educational public policy is the one which is likely to maximize the social surplus of the economy. The social surplus $\sigma$ is measured by the difference between the wealth of the economy (the global output plus the wealth associated with leisure),

and the costs faced by the economy (high-skill and low-skill vacancy costs, and the cost of public education). We have:

$$
\sigma=\ell_{1} y_{1}+\ell_{2} y_{2}+z\left(u_{1}+u_{2}\right)-c_{1} v_{1}-c_{2} v_{2}-\alpha m \mu(\alpha)
$$

where $z$ is the value of leisure. This value of leisure constitutes a proportion of the value for non-market activities $d$ used as the workers' threat point in wage bargaining. The difference between $d$ and $z$ corresponds to extended unemployment benefits. In order to concentrate on the funding of the educational system we implicitly assume that these benefits are financed by a neutral tax as in Holmlund (1998).

Taking into account equations for equilibrium flows in a steady-state (equations (21) to $(24)$ ), the social surplus is given by the following equation:

$$
\begin{aligned}
\sigma= & \frac{\alpha p_{1} y_{1}}{\left(m+s_{1}+p_{1}\right)}+\frac{(1-\alpha) p_{2} y_{2}}{\left(m+s_{2}+p_{2}\right)}+\left(z-c_{1} \theta_{1}\right) \frac{\alpha\left(m+s_{1}\right)}{\left(m+s_{1}+p_{1}\right)} \\
& +\left(z-c_{2} \theta_{2}\right) \frac{(1-\alpha)\left(m+s_{2}\right)}{\left(m+s_{2}+p_{2}\right)}-\alpha m \mu(\alpha)
\end{aligned}
$$


When taxing the increase of productivity associated with a high-skill job, the public decision-maker has to impose a tax rate equal to the following equation (see proof in Appendix A.2):

$$
t_{\sigma}^{*}=t_{\alpha}^{*}-\frac{\theta_{1} Z_{1}\left(m+s_{1}+p_{1}\right) m \mu^{\prime}}{p_{1} Z_{\alpha}\left(y_{1}-y_{2}\right)}
$$

where

$$
Z_{\alpha} \equiv \frac{p_{1} y_{1}+\left(m+s_{1}\right)\left(z-c_{1} \theta_{1}\right)}{\left(m+s_{1}+p_{1}\right)}-\frac{p_{2} y_{2}+\left(m+s_{2}\right)\left(z-c_{2} \theta_{2}\right)}{\left(m+s_{2}+p_{2}\right)}-m \mu(1+\varepsilon)
$$

and

$$
Z_{1} \equiv \frac{\alpha\left(m+s_{1}\right)}{\left(m+s_{1}+p_{1}\right)^{2}}\left[\left(y_{1}-z\right)\left(1-\eta_{1}\right) q_{1}-c_{1}\left(m+s_{1}+\eta_{1} p_{1}\right)\right]
$$

We show in Appendix A.2 that:

- If $Z_{\alpha}>0$, then $t_{\sigma}^{*}<t_{\alpha}^{*}$.

- If $Z_{\alpha}<0$, then $t_{\sigma}^{*}>t_{\alpha}^{*}$.

We cannot know a priori the sign of $Z_{\alpha}$. Therefore we cannot know the relative value of $t_{\alpha}^{*}$ and $t_{\sigma}^{*}$, so we cannot compare the tax rate that maximize the employment level and that which maximizes the social surplus. However, the targets studied in this section and the associated optimal tax rates can be calibrated. We therefore calibrate our model using evidence from 14 European countries. This calibration enables us to determine the level at which the decision-maker should finance the public educational system consistent with the favored target - for the productivity-gap taxation scheme (scenario PG) and also for the two other taxation schemes: taxing profits (scenario P) or wages (scenario W).

\section{Calibration using European evidence}

For all European countries, average public funding accounts for more than 85 per cent of all higher educational expenditure (see European Commission 2011). These countries intend to implement public policy for higher education, as articulated in the European Lisbon strategy 2020 for education. As of dated 2009, this stated that a European average of at least $40 \%$ of the 30-34 year-old age group should have a higher education degree by 2020 (Official Journal of the European Union 2009). National averages have also been fixed, varying from state to state.

In this section we present a calibration of the model using empirical evidence from 14 European countries. We treat the economic situation in 2010 as corresponding to the baseline scenario for public educational policy. We then compare this scenario for each country with the two different objectives that governments could entertain: the employment objective and the social efficiency objective. Finally, we compare the Lisbon target 2020 with observed results. 


\subsection{Baseline calibration}

The calibration made here is on a monthly basis. The discount rate is assumed to be the same for all countries and standardly fixed to an annual rate of $4 \%$, which represents a monthly rate of $0.33 \%$. The job-finding elasticity, as well as bargaining power, are fixed standardly to 0.5 (Pissarides 2000, Hosios 1990). Selected baseline values are summarized in Table 1 and 2 .

\subsubsection{Values fixed according to empirical evidence}

We consider that the uneducated (or low-educated) group is made up of individuals whose educational attainment is below or equal to the level of a high-school diploma. The educated group is therefore composed of individuals with a higher education degree. The unemployment rates $u_{1}$ and $u_{2}$ are given by the number of educated unemployed workers and uneducated unemployed workers in the overall labor-force divided by the total laborforce. The figures are obtained from the 2010 Eurostat LFS (Labour Force Survey) anonymized micro-database.

Regarding the share of educated workers, $\alpha$, we have chosen to treat this as the percentage of the overall population aged 30-34 who have successfully completed university or university-like (tertiary-level) education with an education level ISCED 1997 (International Standard Classification of Education) of 5-6 given by Eurostat. With this figure, we can directly compare the results of our model with the Lisbon strategy target of educated workers for each member-state. Note that the proportion is a little lower in the overall population than in the labor-force, since the less-educated workers are less likely to participate in the labor market. Since our model does not show non-participation, assimilating the total population figure with that of the labor-force does not alter the significance of our conclusions. We indicate in Table 1 the target value for $\alpha$ given by the European Commission in the Lisbon Strategy 2020.

The monthly probability of permanently leaving the labor market, $m$, is derived from the duration of working life indicator (number of expected years spent in the Labor Force) given by Eurostat for 2010. Note that this indicator displays rates of permanent exit from the labor market which are on average much lower than the legal duration of years on the labor market before retirement (duration of pension contribution) standardly used in the calibration of matching models (Ljungqvist and Sargent 1998); but this has a better fit with the reality of the labor market.

The separation rates $s_{1}$ and $s_{2}$ are assimilated to the monthly transition rates from employment to unemployment, for educated and uneducated workers respectively. They are obtained for each country from the annual transition rates calculated from the LFS $2011^{6}$.

Monthly wages for educated, $w_{1}$, and uneducated, $w_{2}$, workers are obtained from the

\footnotetext{
${ }^{6}$ This procedure tends to underestimate transition rates, since transitions occurring within one year are not observed. Note that the EU-SILC (European Union Statistics on Income and Living Conditions) database directly gives monthly transition rates, but with too few observations for most countries.
} 
gross annual earnings in the reference year of the European Structure of Earnings Survey (SES) 2010 and are displayed in euros ${ }^{7}$.

We distinguish between the value of non-market activities $d$, and the value of leisure $z$. The first is obtained from the gross unemployment benefit replacement rate based on the average wage given by the OECD for 2011. We assume the same replacement rate structure for 2010. Regarding the second, since we do not possess a European measure of the value of leisure selected a zero value for all member states.

Finally, the average cost of educating a young individual, $\mu$, corresponds to the monthly tertiary educational expenditures divided by the number of new educated workers in the labor force $(\alpha \times m \times$ labor force). This amount corresponds to the average government spending for each person graduating from tertiary education. Depending on country, the monthly tertiary education expenditures are derived from the annual public expenditures for tertiary education 2010 given by the Classification of the Functions of Government (COFOG) from OECD Statistics, or from public expenditure on tertiary education as a percentage of GDP given by the OECD (2013), where the GDP is given in current prices. Here the educated labor force is the share $\alpha$ of the annual civilian labor force given by the OECD for 2010.

\subsubsection{Studied European countries}

The previously cited data sources are not available for all European member-states. The member-states for which data are available are Belgium (BE), Czech Republic (CZ), Spain (ES), Finland (FI), France (FR), Greece (GR), Hungary (HU), Italy (IT), Luxembourg (LU), Netherlands (NL), Poland (PL), Portugal (PT), Sweden (SE), and Slovakia (SK).

Public commitment to higher education can be evaluated on the government side by observing the proportion of public spending on tertiary education as a percentage of GDP, and on the students side by observing the direct cost of higher education through fees charged and available public support (grants, loans, tax benefits, family allowances). Fee regimes and support for students in tertiary education vary, depending on the country. According to the European Union, among the above countries ${ }^{8}$, Finland, Greece and Sweden were in 2012 among the 9 countries where students (excluding international students from outside the EU/EEA) do not pay for any tuition (European Commission 2012) and receive high level of state support. On the contrary, students in the Czech Republic and Hungary receive only limited support. All students pay fees in Belgium (Flemish Community), the Czech Republic, the Netherlands, Poland, Portugal, and Slovakia. In the other countries - Belgium's French Community, France, Hungary, and Italy - most students pay tuition fees, butnot all of them. As regard expenditure on tertiary educational institutions as a percentage of GDP in 2010 (see OECD 2013), Nordic countries (Finland, the Netherlands, Sweden) had the highest proportion (higher or equal to 1.7). By contrast, the lowest proportion was for Hungary, Slovakia and Italy (equal or lower than 1.0).

\footnotetext{
${ }^{7}$ SES 2010 exchange rates apply when necessary.

${ }^{8}$ The European Commission has only partial information available for Luxembourg, which is thus not part of this comparison (see European Commission 2011).
} 
According to the European Commission (2011, p.45-48), European countries fall into four groups according to fee and grant characteristics: the most generous system is where a majority of students receives grants and a minority pay fees, as is the case for Finland and Sweden; the less generous system the one in which a minority of students receives grants and a majority pay fees, this is the case for Belgium, the Czech Republic, Spain, France, Italy and Poland. It is however worth noting that in the last category, most countries charge very low fees, the highest being Spain with about 763 euros for the undergraduate diploma and 1271 for the graduate diploma, since the educational system is pre-financed. The group in which a minority pay fees and a minority receives grants is considered the most passive group in terms of state intervention. In this group we find Greece and Hungary.

In sum, all European countries included in this study put significant but differing effort into the higher education system where higher education is predominantly funded from public sources, the least interventionist and generous being Hungary.

When looking at the Europe 2020 Agenda target for higher education achievement (first row of Table 1), it is worth noting that while most countries present education targets which are higher than the level reached in 2010 (second row of Table 1), some do display lower targets. This is the case for Finland, Luxembourg, the Netherlands, and Sweden. The targets for Luxembourg, the Netherlands, and Sweden correspond to the European average, raising the question of whether the target was deliberately selected, or was merely never discussed. Finland has a target clearly below the current 2010 level. The next section provides a rationale for this choice.

\subsubsection{Values derived from the model}

Other variables and parameters are deduced using equations from the model. Equations (21) and (23) can be used to retrieve the average monthly job finding rates $p_{1}$ and $p_{2}$.

Outputs $y_{1}$ and $y_{2}$ are deduced from the wage equations in the two sectors. Given the tertiary educational expenditures actually realized in 2010, the tax rate $t$ which would have financed them can be calculated according to the tax base. The tax rate that appears in the baseline thus depends on the taxation scenario applied. Baseline inferred values for the tax rate are presented, for each taxation scenario (PG, P, and W) in Table 2.

Since we do not have clear estimations for each of the European countries considered, the cost of a vacancy is fixed in proportion to the output of each sector, using empirical findings from Hagedorn and Manovskii (2006) on US data. According to them, the capital cost of a vacancy corresponds to 0.474 times average productivity, and the labor cost of a vacancy equals 0.11 times average productivity. All in all, the total cost of a vacancy therefore corresponds to 0.584 of the productivity in each sector.

Private surpluses are derived from equations (13) and (15) for the initial scenario. The values for $q_{i}$ are then retrieved from the equilibrium equations (14) and (16). Sector tightness $\theta_{i}$ is obtained from its definition $\theta_{i}=p_{i} / q_{i}$. We assume the matching functions to

be Cobb-Douglas with matching parameter $M_{i}$, so that $h_{i}=M_{i} v_{i}^{\eta_{i}} u_{i}^{1-\eta_{i}}$ is the matching function prevailing in sector $i$. As a consequence, we have $M_{i}=\frac{p_{i}}{\theta_{1}^{\left(1-\eta_{1}\right)}}$. Employment 
Table 1: Parameters and variables whose value is fixed

\begin{tabular}{lrrrrrrr}
\hline Country & Belgium & Czech Republic & \multicolumn{2}{r}{ Spain } & Finland & France & Greece \\
EU code & BE & CZ & ES & FI & FR & GR & HU \\
\hline Target to $\alpha$ & 0.470 & 0.320 & 0.440 & 0.420 & 0.500 & 0.320 & 0.303 \\
$\alpha$ & 0.444 & 0.204 & 0.406 & 0.457 & 0.435 & 0.284 & 0.257 \\
$m$ & 0.00237 & 0.00227 & 0.00224 & 0.00209 & 0.00226 & 0.00238 & 0.00263 \\
$u_{1}$ & 0.01740 & 0.00439 & 0.03594 & 0.01218 & 0.01718 & 0.02339 & 0.00881 \\
$u_{2}$ & 0.06502 & 0.06977 & 0.14507 & 0.05965 & 0.08026 & 0.09892 & 0.11274 \\
$s_{1}$ & 0.00106 & 0.00108 & 0.00296 & 0.00109 & 0.00201 & 0.00278 & 0.00152 \\
$s_{2}$ & 0.00263 & 0.00329 & 0.00547 & 0.00307 & 0.00358 & 0.00477 & 0.00510 \\
$w_{1}$ & 5238.78 & 1505.69 & 3017.89 & 3690.14 & 3979.34 & 2705.39 & 1085.60 \\
$w_{2}$ & 2790.96 & 796.08 & 1698.62 & 2585.61 & 2389.33 & 1732.70 & 547.27 \\
$d$ & 1184.41 & 58.41 & 645.69 & 1010.20 & 988.73 & 207.13 & 75.61 \\
$\mu$ & 86296 & 51175 & 48026 & 133666 & 78996 & 47507 & 27577 \\
\hline
\end{tabular}

\begin{tabular}{|c|c|c|c|c|c|c|c|}
\hline $\begin{array}{l}\text { Country } \\
\text { EU code }\end{array}$ & $\begin{array}{r}\text { Italy } \\
\text { IT }\end{array}$ & $\begin{array}{r}\text { Luxembourg } \\
\text { LU }\end{array}$ & $\begin{array}{r}\text { Netherlands } \\
\text { NL }\end{array}$ & $\begin{array}{c}\text { Poland } \\
\text { PL }\end{array}$ & $\begin{array}{r}\text { Portugal } \\
\text { PT }\end{array}$ & $\begin{array}{r}\text { Sweden } \\
\mathrm{SE}\end{array}$ & $\begin{array}{r}\text { Slovakia } \\
\text { SK }\end{array}$ \\
\hline Target to $\alpha$ & 0.260 & 0.400 & 0.400 & 0.450 & 0.400 & 0.400 & 0.400 \\
\hline$\alpha$ & 0.198 & 0.461 & 0.414 & 0.353 & 0.235 & 0.453 & 0.221 \\
\hline$m$ & 0.00259 & 0.00243 & 0.00197 & 0.00243 & 0.00208 & 0.00192 & 0.00237 \\
\hline$u_{1}$ & 0.00916 & 0.01247 & 0.00778 & 0.01213 & 0.00996 & 0.01493 & 0.01006 \\
\hline$u_{2}$ & 0.07195 & 0.02687 & 0.03597 & 0.08628 & 0.09311 & 0.07110 & 0.13215 \\
\hline$s_{1}$ & 0.00148 & 0.00088 & 0.00103 & 0.00140 & 0.00293 & 0.00109 & 0.00098 \\
\hline$s_{2}$ & 0.00294 & 0.00155 & 0.00152 & 0.00339 & 0.00542 & 0.00214 & 0.00300 \\
\hline$w_{1}$ & 3647.29 & 6252.74 & 3778.21 & 1125.99 & 2511.64 & 3011.39 & 1210.31 \\
\hline$w_{2}$ & 2270.67 & 3128.84 & 2043.25 & 714.33 & 1145.32 & 2355.63 & 644.96 \\
\hline$d$ & 270.83 & 968.53 & 849.21 & 83.29 & 571.64 & 979.49 & 64.52 \\
\hline$\mu$ & 89078 & 23676 & 122976 & 23653 & 62516 & 137120 & 32047 \\
\hline
\end{tabular}

levels are directly obtained via equations (22) and (24). We assume the elasticity of the average cost of education, denoted by $\varepsilon$, to be of the shape $\varepsilon=\alpha x$ where the parameter $x$ is defined as $x=\frac{\log (\mu)}{\alpha}$. Finally the value for the social surplus $\sigma$ is obtained from its equation.

\subsection{Policy results: optimal taxation and the Lisbon strategy}

We now test the two different policies that a policy-maker could introduce. This time all the parameters of the model are fixed and variables are defined according to equations of the model. The non-linear optimization resolution is performed using the General Algebraic Modeling System software (GAMS release 24.2.1). While the software succeeds in giving the optimal values in the PG scenario for most countries, the mathematical 
Table 2: Tax rate at baseline according to the three scenarios

\begin{tabular}{lrrrrrrr}
\hline Country & Belgium & Czech Republic & \multicolumn{2}{r}{ Spain } & Finland & France & \multicolumn{2}{r}{ Greece } & Hungary \\
EU code & BE & CZ & ES & FI & FR & GR & HU \\
\hline PG & 0.07958 & 0.15005 & 0.08241 & 0.22634 & 0.10975 & 0.10941 & 0.12972 \\
P & 0.25119 & 0.22155 & 0.13921 & 0.40046 & 0.25648 & 0.10917 & 0.19774 \\
W & 0.02516 & 0.02696 & 0.02320 & 0.04416 & 0.02748 & 0.01811 & 0.03029 \\
\hline \multicolumn{10}{c}{ Country } & Italy & Luxembourg & Netherlands & Poland & Portugal & Sweden & Slovakia \\
EU code & IT & LU & NL & PL & PT & SE & SK \\
\hline PG & 0.14940 & 0.01810 & 0.12609 & 0.14422 & 0.08839 & 0.35382 & 0.13282 \\
P & 0.15449 & 0.10712 & 0.45551 & 0.18287 & 0.24577 & 0.37531 & 0.12855 \\
W & 0.01947 & 0.00603 & 0.03777 & 0.02591 & 0.02295 & 0.04895 & 0.02500 \\
\hline
\end{tabular}

complexity of the other scenarios prevented the software from functioning correctly, leading to a false unfeasible solution. We overcame this technical limitation by forcing the software to run the model over the full potential range of the tax, that is, $t \in[0,1]$ with an increment of 0.001 . While for two scenarios the software was able to converge properly on the optimal solution for the full range of the tax, that is 0.001 to 0.999 , one scenario ran only until a certain value of the tax, after which system resolution became false and unfeasible.

Appendix A.3 presents the graphics resulting from this resolution method, for each country. Scenarios (tax on productivity gap, tax on profits, tax on wages) are displayed in the columns and objectives (highest education share possible, employment maximization, social surplus maximization) are displayed in the rows. Appendix A.4 presents for each country, from Table 31 to Table 44, the optimization values of the tax; wages; the employment levels (for educated employment, uneducated employment, and total); the share of educated workers; and the social surplus, for each of the four following objectives: the highest educated share possible, maximization of the total employment level, maximization of the social surplus, and values reached when the Lisbon target is matched.

\subsubsection{Which financing scheme for which objective?}

The calibrations made for 14 European countries reveal some particularly interesting results (Tables 31 to 44). We observe very consistent results from one country to the other regarding the most adequate taxation schemes that a country should consider in order to reach such and such public policy objective.

If the objective chosen by the government is the maximization of employment (second column of each scenario, row $\ell$ ), a financing scheme based on the productivity gap $\left(y_{1}-y_{2}\right)$ (i.e. on educational benefits), that is to say scenario PG, gives the best results for all 14 countries. Note that compared with the situation observed in 2010, maximizing total employment would suppose an increase in the amount of public expenditure dedicated 
to tertiary education whatever the selected financing scheme, i.e. the tax rate $t$ that maximizes employment (row $t$ in Tables 31 to 44 ) is higher than at the baseline (Table 2).

The maximization of the social surplus (third column of each scenario, row $\sigma$ ) leads to more differentiated results. For 11 of the 14 studied countries, that is to say for the Czech Republic (Table 32), Finland (Table 34), France (Table 35), Greece (Table 36), Hungary (Table 37), Italy (Table 38), The Netherlands (Table 40), Poland (Table 41), Portugal (Table 42), Sweden (Table 43), and Slovakia (Table 44), taxing profits (scenario P) is the scenario that leads to the highest social surplus. Maximizing this objective would suppose a reduction in educational expenditures compared to costs in 2010 (tax rate at baseline).

In the three other countries - namely Belgium (Table 31), Spain (Table 33), and Luxembourg (Table 39) - taxing the productivity gap between educated and uneducated workers is the scenario that would lead to the highest social surplus. For Belgium and Luxembourg, reaching the social surplus maximization objective would require an increase in the tax rate and in tertiary education spending.

Having the previous results in mind, it is not surprising to observe that whatever the financing scheme is, the tax rate that should be introduced (row $t$ ), and the desirable share of new educated workers that would result from it (row $\alpha$ ), is higher when the government objective is to maximize global employment (second column) than when the government objective is to maximize the social surplus (third column). Almost all countries should thus strike a balance between well-being and employment ${ }^{9}$.

\subsubsection{Comparison of the Lisbon target and public policy objectives}

Following the first Lisbon strategy for the period 2000-2010, the Europe 2020 Agenda proposed in 2010 by the European Commission lead European countries to decide on precise numerical indicators that each country should achieve by 2020 in respect of the proportion of young people with tertiary education degrees. Our results permit comparison of the stated targets with two public policy objectives - the employment level and the social surplus - for most countries. In 2010, the Northern countries (Finland, Luxembourg, The Netherlands, Sweden) had already exceeded their target, while in all the other countries the Agenda 2020 criteria implies an increase in the share of educated workers.

For 4 of the 14 countries studied, the Lisbon target (fourth column for each scenario) seems impossible to achieve given the starting conditions in 2010, and whatever the scheme of taxation used. These countries are the Czech Republic, Italy, Portugal and Slovakia. For Poland the Lisbon target is unachievable only for the productivity gap scenario. For the 9 other countries, the Lisbon target can be reached with a tax rate appropriate to each of the four financing schemes. Countries can be split into four groups:

\footnotetext{
${ }^{9}$ Note that our results are interpreted using the current production technology. Introducing a skill-bias could possibly shift the employment and social surplus criteria.
} 
Case 1: For Nordic countries - Finland, the Netherlands, and Sweden - the Lisbon target ( $42 \%$ for Finland, $40 \%$ for the Netherlands and Sweden) is very close to the share of educated workers that maximizes the social surplus whatever the financing scheme might be. For the Netherlands, the two objectives are even equal in the productivity gap taxation scenario. This gives a strong political rationale for the selected Lisbon indicator, which was, for all three countries, lower than the educated share reached in 2010, that is to say when the indicator was set. The employment maximization objective would however require an increase in the share of educated workers. In the productivity gap scenario, the share of educated workers that would maximize employment is $50.4 \%$ for Finland, $45.35 \%$ for the Netherlands, and $48.76 \%$ for Sweden. Those figures are lower and closer to the Lisbon target in the profits taxation scenario (respectively $45.39 \%, 40.71 \%$ and $44.49 \%$ ).

Case 2: Luxembourg's target of $40 \%$ is too low compared with the employment maximization or the well-being objective, which would require a much greater share of educated workers, that is between $52.89 \%$ and $56.63 \%$ in the productivity gap scenario and $52.83 \%$ and $53.73 \%$ in the profits scenario. Note that Luxembourg also belongs to the countries selecting an education target lower than the level reached when the indicator was set. Our results thus question this choice ${ }^{10}$.

Case 3: Conversely, in France, Greece, Hungary and Poland, the Lisbon target is too high compared with the share of educated workers that would maximize either employment or further the social surplus, whatever the financing scheme. For instance, the gap is very significant for France, where the Lisbon target has been set at 50\%, while in the profits taxation scenario the social surplus maximization requires an educated share of $42.55 \%$ and $44.62 \%$ for maximizing employment. The gap is lower in the productivity gap scenario, with respectively $43 \%$ and $49.3 \%$. Similar differences can be observed for the other countries of this group.

Case 4: In the case of Belgium and Spain, the result depends on the taxation strategy adopted. With a financing scheme based on wages or profits, the situation is similar to countries belonging to the previous group. With a tax on the productivity gap, which remains the best taxation scenario for the two countries, the Lisbon target for higher education ( $47 \%$ for Belgium and $44 \%$ for Spain) is intermediate between the share of educated workers that would maximize employment $(50.17 \%$ for Belgium and $46.28 \%$ for Spain) and that which would maximize the social surplus $(44.75 \%$ and $41.36 \%$ respectively).

Figures 1 and 2 presented in Appendix A.5 synthesize the distance between the 2010 values of the tax rate (axis) and the educated share (ordinate) and the objective considered (Lisbon target, social surplus, employment) for the countries cited above Poland excluded.

\footnotetext{
${ }^{10}$ The European Commission has only partial information available regarding the higher education system and its financing in Luxembourg. The figures presented in our work have therefore to be taken very cautiously.
} 
Figure 1 shows the Productivity Gap taxation scenario, and figure 2 shows the Profits scenario. The figures underline one example of a country for case 1 (Finland), for case 3 (France), and for case 4 (Belgium for figure 1 and France once again for figure 2).

\section{Conclusion}

In Europe, the tertiary educational system is largely financed by public subsidies. During recent years, and in spite of the economic and financial crisis, funding for tertiary education has not been reduced, whereas other areas of public spending were sharply reduced. Such consistent financing of the higher educational system is explained by government desire to increase the share of educated workers, so that newcomers to the labor market would fit with firms' needs better. This would also improve the integration of the labor market. The increase in the educated workforce also encourages firms to create a greater number of high-skill jobs, which are more productive than the low-skill jobs.

Our results support a range of conclusions. Firstly, taxation schemes do not all have the same efficiency in terms of economic policy. A government seeking to maximize employment should base the financing of higher education on the productivity gap between educated and uneducated workers. Depending on the country, achieving optimal social well-being requires a choice between the profits taxation scheme or the productivity gap taxation scheme. Taxing wages never shows up as a desirable way of financing educational expenditure.

Second, reaching the employment maximization objective always requires higher educational spending, and the tax rate has to be higher than the one needed to maximize the social surplus, regardless of the taxation scheme considered. Except for Belgium and Spain, public educational expenditure of 2010 is higher than that which would maximize the social surplus, but lower than that which would maximize global employment.

Third, the Lisbon target, set for each country by the European Commission in the Europe 2020 Agenda, can be compared with the two previously cited public policy objectives, provided of course that this target is achievable, which excludes the Czech Republic, Italy, Portugal and Slovakia. From this point of view, all countries are not in the same situation. Finland, The Netherlands and Sweden have chosen a target that coincides with the share of educated workers that maximizes the social surplus. Luxembourg have set a target too low to maximize well-being. In contrast, France, Greece, Hungary and Poland have set excessive targets, even when compared with the share of educated workers likely to maximize the employment level. In the case of Belgium and Spain, the target is intermediary between the two economic policy objectives when considering the productivity gap taxation scheme, which is the taxation scheme most advantageous to them.

Our results have to be treated with caution since to some extent they depend on our methodological choices. Opting for perfect segmentation of the labor market prevents uneducated workers from accessing high-skill jobs through on-the-job training. Whatever the financing scheme, this assumption overestimates the benefit of higher education and thus overestimates the proportion of newcomers that should enter the labor market with 
a higher education degree. A strong assumption is also used in our calibration, based as it is upon a specific functional form of the relationship between average educational cost and the share of educated workers. This function determines the tax increase necessary to increase the educated share. Further research will permits us to explore these two aspects.

\section{References}

Acemoglu, D., 2001. Good Jobs versus Bad Jobs, Journal of Labor Economics 19(1), $1-21$.

Benabou, R., 2002. Tax and Education Policy in a Heterogeneous-Agent Economy: What Levels of Redistribution Maximize Growth and Efficiency?, Econometrica 70(2), 481-517.

Blankenau, W.F. and N.B. Simpson, 2004. Public education expenditures and growth, Journal of Development Economics 73(2), 583-605.

European Commission, 2011. Modernisation of Higher Education in Europe: Funding and the Social Dimension, EACEA Eurydice Report 2011.

European Commission, 2012. Report reveals wide fluctuations in cost of higher education and support for students, Press Release, Brussels, 10 September 2012, IP/12/947.

European Commission, 2013. Funding of Education in Europe 2000-2012: The Impact of the Economic Crisis, EACEA Eurydice Report 2013, Luxembourg: Publications Office of the European Union.

Gavrel, F., I. Lebon and T. Rebiere, 2010. Career paths, unemployment, and the efficiency of the labor market: Should youth employment be subsidized?, Journal of Public Economic Theory 12, 533-560.

Hagedorn M. and I. Manovskii, 2008. The Cyclical Behavior of Equilibrium Unemployment and Vacancies Revisited, American Economic Review 98(4), 1692-1706.

Holmlund, B., 1998. Unemployment Insurance in Theory and Practice, Scandinavian Journal of Economics 100(1), 113-141.

Hosios, A., 1990. On the Efficiency of Matching and Related Models of Search and Unemployment, Review of Economic Studies 57(2), 279-298.

Kaganovich, M. and I. Zilcha, 1999. Education, social security, and growth, Journal of Public Economics 71(2), 289-309.

Keeling, R., 2006. The Bologna Process and the Lisbon Research Agenda: the European Commission's expanding role in higher education discourse, European Journal of Education 41(2), 203-223. 
Ljungqvist, L. and T.J. Sargent, 1998. The European Unemployment Dilemma, Journal of Political Economy 106(3), 514-550.

Moen, E.R. and A. Rosén, 2004. Does Poaching Distort Training?" Review of Economic Studies 71(4), 1143-1162.

OECD, 2013. Education at a Glance 2013: OECD Indicators, OECD Publishing. http: //dx.doi.org/10.1787/eag-2013-en

Official Journal of the European Union, 2009. Council conclusions of 12 May 2009 on a strategic framework for European cooperation in education and training ('ET 2020'), Notices from European Union Institutions and Bodies, 2009/C 119/02, http://eurlex .europa.eu/LexUriServ/LexUriServ.do?uri=0J : C : 2009: 119:0002:0010:EN :PDF

Pissarides, C.A., 2000. Equilibrium Unemployment Theory, 2nd edition, Cambridge, MA: MIT Press.

Siew, L.Y. and J. Zhang, 2013. Socially optimal social security and education subsidization in a dynastic model with human capital externalities, fertility and endogenous growth, Journal of Economic Dynamics and Control 37(1), 154-175.

Sylwester K., 2002. Can education expenditures reduce income inequality?, Economics of Education Review 21(1), 43-52.

Zhang J., 1996. Optimal Public Investments in Education and Endogenous Growth, The Scandinavian Journal of Economics 98(3), 387-404. 


\section{A Appendix}

\section{A.1 Derivation of $t_{\ell}^{*}$}

The evolution of global employment following a change in the tax rate $t$, defined by equation (32), taking into account the impact of the tax rate on the high-skill sector tightness $\theta_{1}$, and on the share of educated workers $\alpha$ :

$$
\frac{d \ell}{d t}=\frac{\partial \ell}{\partial t}+\frac{\partial \ell}{\partial \alpha} \frac{d \alpha}{d t}+\frac{\partial \ell}{\partial \theta_{1}} \frac{\partial \theta_{1}}{\partial t}=0
$$

Direct impacts on $\ell$ of a change in $t, \alpha$, and $\theta_{1}$ are:

$$
\begin{aligned}
& \frac{\partial \ell}{\partial t}=0 \\
& \frac{\partial \ell}{\partial \alpha}=\frac{p_{1}}{\left(m+s_{1}+p_{1}\right)}-\frac{p_{2}}{\left(m+s_{2}+p_{2}\right)} \\
& \frac{\partial \ell}{\partial \theta_{1}}=\frac{\alpha\left(m+s_{1}\right) p_{1}^{\prime}}{\left(m+s_{1}+p_{1}\right)^{2}}=\frac{\alpha\left(m+s_{1}\right)\left(1-\eta_{1}\right) p_{1}}{\theta_{1}\left(m+s_{1}+p_{1}\right)^{2}}
\end{aligned}
$$

Combining those results with the total impact of $t$ on $\alpha$ and $\theta_{1}$ gives:

$$
\begin{aligned}
& \frac{d \alpha}{d t}= \frac{p_{1}\left(y_{1}-y_{2}\right)\left[\theta_{1}\left(1-\eta_{1}\right) \beta c_{1}+\eta_{1}(1-\beta)\left[\left(y_{1}-y_{2}\right)(1-t)+y_{2}-d\right]\right]}{\left(m+s_{1}+p_{1}\right) m \mu^{\prime}\left[\theta_{1}\left(1-\eta_{1}\right) \beta c_{1}+\eta_{1}(1-\beta)\left[\left(y_{1}-y_{2}\right)(1-t)+y_{2}-d\right]\right]} \\
&- \frac{p_{1}\left(y_{1}-y_{2}\right)\left(1-\eta_{1}\right)(1-\beta)\left(t\left(y_{1}-y_{2}\right)-m \mu(\alpha)\right)}{\left(m+s_{1}+p_{1}\right) m \mu^{\prime}\left[\theta_{1}\left(1-\eta_{1}\right) \beta c_{1}+\eta_{1}(1-\beta)\left[\left(y_{1}-y_{2}\right)(1-t)+y_{2}-d\right]\right]} \\
& \frac{\partial \theta_{1}}{\partial t}=\frac{-\theta_{1}(1-\beta)\left(y_{1}-y_{2}\right)}{\theta_{1}\left(1-\eta_{1}\right) \beta c_{1}+\eta_{1}(1-\beta)\left[\left(y_{1}-y_{2}\right)(1-t)+y_{2}-d\right]}
\end{aligned}
$$

We have:

$\frac{d \ell}{d t}=\frac{p_{1}\left(y_{1}-y_{2}\right) \times \psi}{\left(m+s_{1}+p_{1}\right)^{2}\left(m+s_{2}+p_{2}\right) m \mu^{\prime}\left[\theta_{1}\left(1-\eta_{1}\right) \beta c_{1}+\eta_{1}(1-\beta)\left[\left(y_{1}-y_{2}\right)(1-t)+y_{2}-d\right]\right]}$

where

$$
\begin{aligned}
\psi= & {\left[p_{1}\left(m+s_{2}\right)-p_{2}\left(m+s_{1}\right)\right]\left[\theta_{1}\left(1-\eta_{1}\right) \beta c_{1}+\eta_{1}(1-\beta)\left[\left(y_{1}-y_{2}\right)(1-t)+y_{2}-d\right]\right] } \\
& -\left[p_{1}\left(m+s_{2}\right)-p_{2}\left(m+s_{1}\right)\right]\left(1-\eta_{1}\right)(1-\beta)\left(t\left(y_{1}-y_{2}\right)-m \mu(\alpha)\right) \\
& -\left(m+s_{1}\right)\left(1-\eta_{1}\right)(1-\beta)\left(m+s_{2}+p_{2}\right) m \alpha \mu^{\prime}
\end{aligned}
$$

The value of $t_{\ell}^{*}$ is obtained by equalizing $\psi$ to zero. We have:

$$
\begin{aligned}
t_{\ell}^{*}= & \frac{(1-\beta)\left(1-\eta_{1}\right) m \mu(\alpha)+\left(1-\eta_{1}\right) c_{1} \beta \theta_{1}+(1-\beta) \eta_{1}\left(y_{1}-d\right)}{(1-\beta)\left(y_{1}-y_{2}\right)} \\
& -\frac{\left(1-\eta_{1}\right)\left(m+s_{1}\right)\left(m+s_{2}+p_{2}\right) m \varepsilon \mu(\alpha)}{\left(y_{1}-y_{2}\right)\left(p_{1}\left(m+s_{2}\right)-p_{2}\left(m+s_{1}\right)\right)}
\end{aligned}
$$


That is to say:

$$
t_{\ell}^{*}=t_{\alpha}^{*}-\frac{\left(1-\eta_{1}\right)\left(m+s_{1}\right)\left(m+s_{2}+p_{2}\right) m \varepsilon \mu(\alpha)}{\left(y_{1}-y_{2}\right)\left(p_{1}\left(m+s_{2}\right)-p_{2}\left(m+s_{1}\right)\right)}
$$

When the second term is negative, i.e. when $\left(p_{1}\left(m+s_{2}\right)-p_{2}\left(m+s_{1}\right)\right)>0$, the sign of $t_{\ell}^{*}$ is indeterminate. Uncertainty can be removed by replacing $m \mu(\alpha)$, in the second term of the previous equation, by its value obtained from equation (25). We have:

$$
\begin{aligned}
t_{\ell}= & \frac{(1-\beta)\left(1-\eta_{1}\right) m \mu(\alpha)+\left(1-\eta_{1}\right) c_{1} \beta \theta_{1}+(1-\beta) \eta_{1}\left(y_{1}-d\right)}{(1-\beta)\left(y_{1}-y_{2}\right)} \\
& -\frac{\left(1-\eta_{1}\right)\left(m+s_{1}\right)\left(m+s_{2}+p_{2}\right) \varepsilon t_{\ell} p_{1}}{\left(m+s_{1}+p_{1}\right)\left(p_{1}\left(m+s_{2}\right)-p_{2}\left(m+s_{1}\right)\right)}
\end{aligned}
$$

For the purpose of simplification, the previous equation can be written using the following generic form:

$$
t_{\ell}=\frac{X_{1}}{X_{2}}-\frac{X_{3}}{X_{4}} t_{\ell}
$$

where the terms corresponding to $X_{1}, X_{2}$, and $X_{3}$ are always positive, whereas the term $X_{4}$ has the sign of $\left[p_{1}\left(m+s_{2}\right)-p_{2}\left(m+s_{1}\right)\right]$. We can thus write $t_{\ell}^{*}$ as follows:

$$
t_{\ell}^{*}=\frac{X_{1}}{X_{2}} \frac{X_{4}}{\left(X_{3}+X_{4}\right)}
$$

If $\left[p_{1}\left(m+s_{2}\right)-p_{2}\left(m+s_{1}\right)\right]$ and $X_{4}$ have positive values, then $t_{\ell}^{*}$ is below $t_{\alpha}^{*}=\frac{X_{1}}{X_{2}}$, but remains positive.

\section{A.2 Derivation of $t_{\sigma}^{*}$}

The evolution of the social surplus (equation (35)) following a change in the tax rate $t$, takes into account two indirect effects: the effect of the tax rate on tightness $\theta_{1}$, and on the share of educated workers $\alpha$ :

$$
\frac{d \sigma}{d t}=0 \Leftrightarrow \frac{\partial \sigma}{\partial t}+\frac{\partial \sigma}{\partial \alpha} \frac{d \alpha}{d t}+\frac{\partial \sigma}{\partial \theta_{1}} \frac{\partial \theta_{1}}{\partial t}=0
$$

The direct impact on $\sigma$ of a change in $t$ is equal to zero:

$$
\frac{\partial \sigma}{\partial t}=0
$$

The impacts of a variation of $\alpha$ and $\theta_{1}$ on $\sigma$ are given by:

$$
\begin{gathered}
\frac{\partial \sigma}{\partial \alpha}=\frac{p_{1} y_{1}+\left(m+s_{1}\right)\left(z-c_{1} \theta_{1}\right)}{\left(m+s_{1}+p_{1}\right)}-\frac{p_{2} y_{2}+\left(m+s_{2}\right)\left(z-c_{2} \theta_{2}\right)}{\left(m+s_{2}+p_{2}\right)}-m \mu(1+\varepsilon) \\
\frac{\partial \sigma}{\partial \theta_{1}}=\frac{\alpha\left(m+s_{1}\right)}{\left(m+s_{1}+p_{1}\right)^{2}}\left[\left(y_{1}-z\right)\left(1-\eta_{1}\right) q_{1}-c_{1}\left(m+s_{1}+\eta_{1} p_{1}\right)\right]
\end{gathered}
$$

In order to simplify the mathematics we now use the variables $Z_{\alpha}$ and $Z_{1}$ for respectively the terms $\frac{\partial \sigma}{\partial \alpha}$ and $\frac{\partial \sigma}{\partial \theta_{1}}$. Notice that these two terms do not depend on $t$. We have:

$$
Z_{\alpha} \equiv \frac{p_{1} y_{1}+\left(m+s_{1}\right)\left(z-c_{1} \theta_{1}\right)}{\left(m+s_{1}+p_{1}\right)}-\frac{p_{2} y_{2}+\left(m+s_{2}\right)\left(z-c_{2} \theta_{2}\right)}{\left(m+s_{2}+p_{2}\right)}-m \mu(1+\varepsilon)
$$




$$
Z_{1} \equiv \frac{\alpha\left(m+s_{1}\right)}{\left(m+s_{1}+p_{1}\right)^{2}}\left[\left(y_{1}-z\right)\left(1-\eta_{1}\right) q_{1}-c_{1}\left(m+s_{1}+\eta_{1} p_{1}\right)\right]
$$

The optimal tax rate $t_{\sigma}^{*}$ can therefore be deduced from the following equation:

$$
Z_{\alpha} \frac{d \alpha}{d t}+Z_{1} \frac{\partial \theta_{1}}{\partial t}=0
$$

Replacing $\frac{d \alpha}{d t}$ and $\frac{\partial \theta_{1}}{\partial t}$ by their equation (given in Appendix A.2), we can rewrite the previous equation as follows:

$$
\begin{aligned}
Z_{\alpha} p_{1}\left(y_{1}-y_{2}\right) \quad & {\left[\frac{\theta_{1}\left(1-\eta_{1}\right) \beta c_{1}+\eta_{1}(1-\beta)\left[\left(y_{1}-y_{2}\right)(1-t)+y_{2}-d\right]}{\left(m+s_{1}+p_{1}\right) m \mu^{\prime}\left[\theta_{1}\left(1-\eta_{1}\right) \beta c_{1}+\eta_{1}(1-\beta)\left[\left(y_{1}-y_{2}\right)(1-t)+y_{2}-d\right]\right]}\right.} \\
& \left.-\frac{\left(1-\eta_{1}\right)(1-\beta)\left(t\left(y_{1}-y_{2}\right)-m \mu(\alpha)\right)}{\left(m+s_{1}+p_{1}\right) m \mu^{\prime}\left[\theta_{1}\left(1-\eta_{1}\right) \beta c_{1}+\eta_{1}(1-\beta)\left[\left(y_{1}-y_{2}\right)(1-t)+y_{2}-d\right]\right]}\right] \\
-Z_{1} & \frac{\theta_{1}(1-\beta)\left(y_{1}-y_{2}\right)}{\theta_{1}\left(1-\eta_{1}\right) \beta c_{1}+\eta_{1}(1-\beta)\left[\left(y_{1}-y_{2}\right)(1-t)+y_{2}-d\right]}=0
\end{aligned}
$$

After simplification we deduce:

$$
\begin{aligned}
& p_{1}\left(y_{1}-y_{2}\right) Z_{\alpha}\left[\theta_{1}\left(1-\eta_{1}\right) \beta c_{1}+\eta_{1}(1-\beta)\left(y_{1}-d\right)+\left(1-\eta_{1}\right)(1-\beta) m \mu(\alpha)\right] \\
& -\theta_{1}(1-\beta)\left(y_{1}-y_{2}\right) Z_{1}\left(m+s_{1}+p_{1}\right) m \mu^{\prime}=p_{1}\left(y_{1}-y_{2}\right) Z_{\alpha} t(1-\beta)\left(y_{1}-y_{2}\right)
\end{aligned}
$$

Finally we have:

$$
\begin{aligned}
t_{\sigma}^{*}= & \frac{(1-\beta)\left(1-\eta_{1}\right) m \mu(\alpha)+\left(1-\eta_{1}\right) c_{1} \beta \theta_{1}+(1-\beta) \eta_{1}\left(y_{1}-d\right)}{(1-\beta)\left(y_{1}-y_{2}\right)} \\
& -\frac{\theta_{1} Z_{1}\left(m+s_{1}+p_{1}\right) m \mu^{\prime}}{p_{1} Z_{\alpha}\left(y_{1}-y_{2}\right)}
\end{aligned}
$$

We can show by replacing $c_{1}$ by its equation deduced from (14) that, around the equilibrium (under the Hosios condition $\beta=\eta_{1}$ ), $Z_{1}$ is always positive. The sign of $Z_{\alpha}$ remains however indeterminate. 


\section{A.3 Graphical results}

Table 3: Tax rate impact: PG and P scenarios, Belgium (BE)

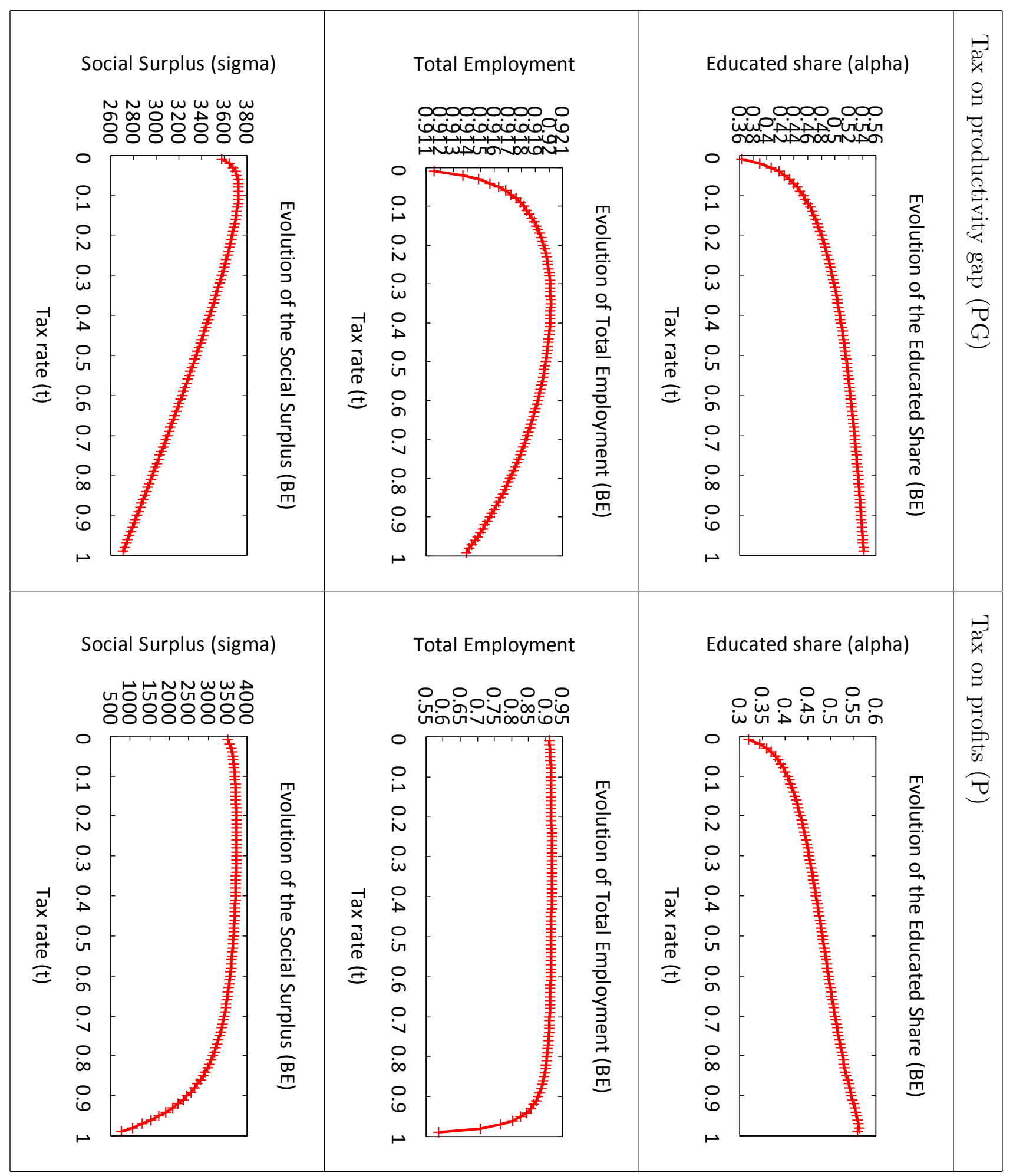


Table 4: Tax rate impact: W scenario, Belgium (BE)

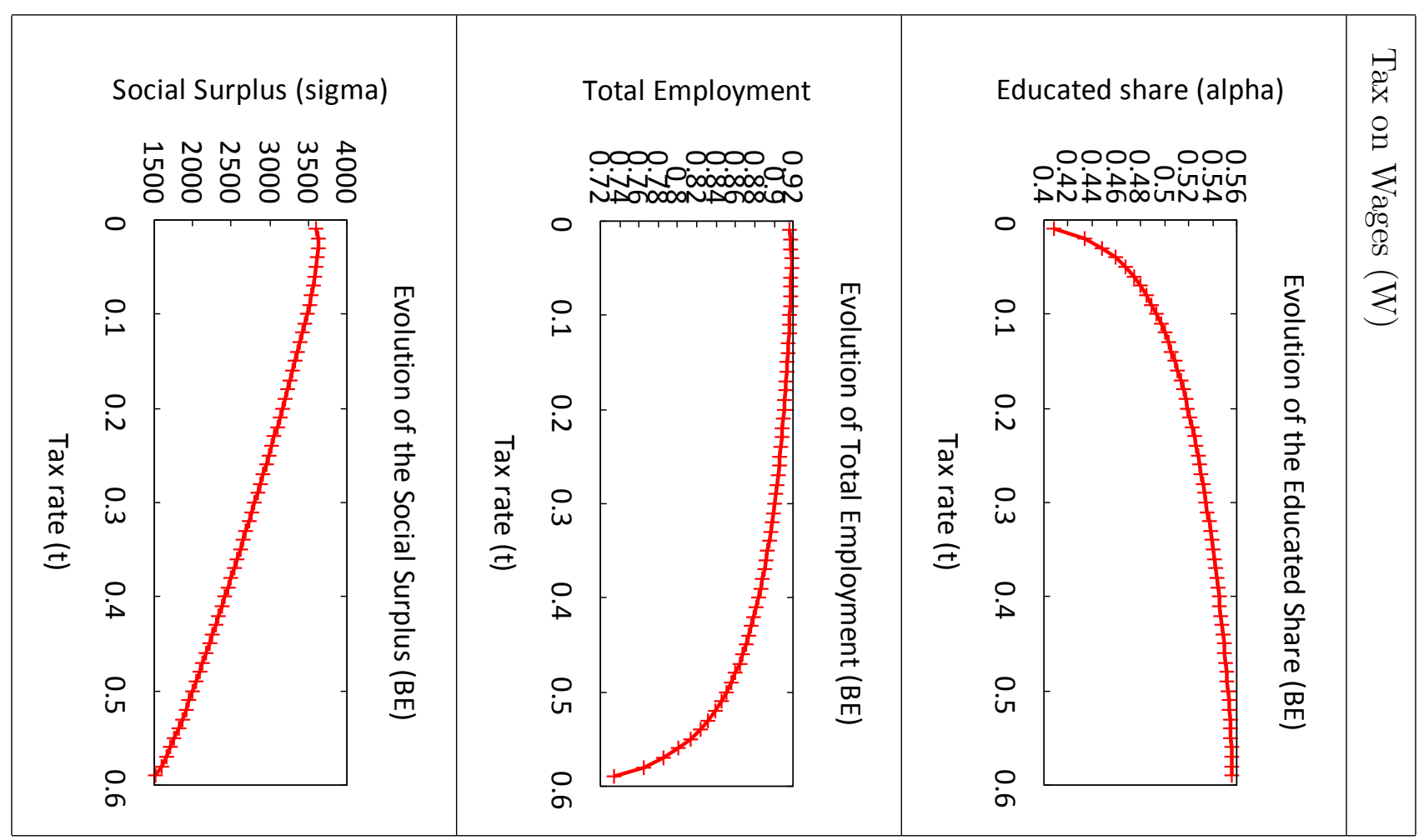


Table 5: Tax rate impact: PG and P scenarios, Czech Republic (CZ)

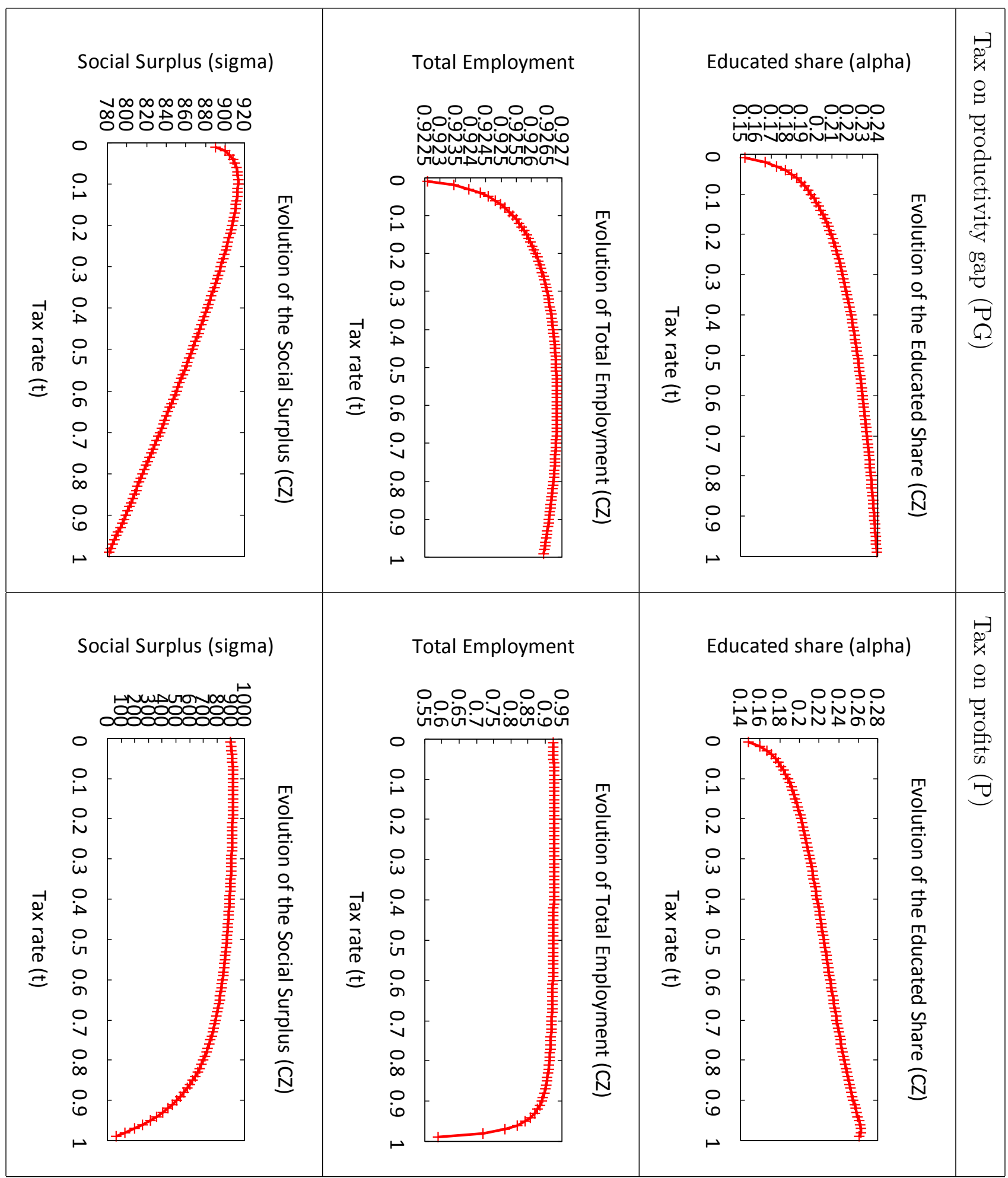


Table 6: Tax rate impact: W scenario, Czech Republic (CZ)

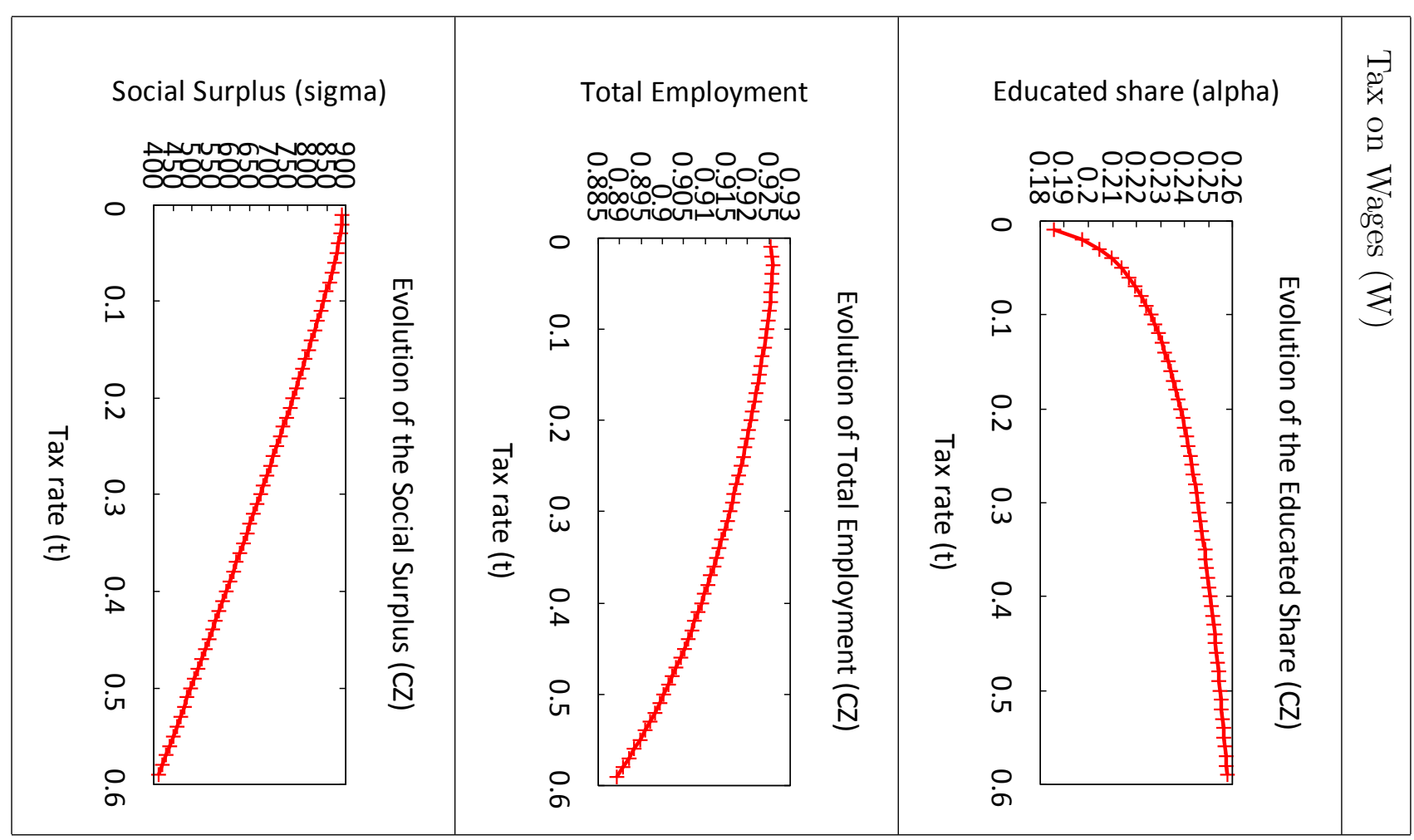


Table 7: Tax rate impact: PG and P scenarios, Spain (ES)

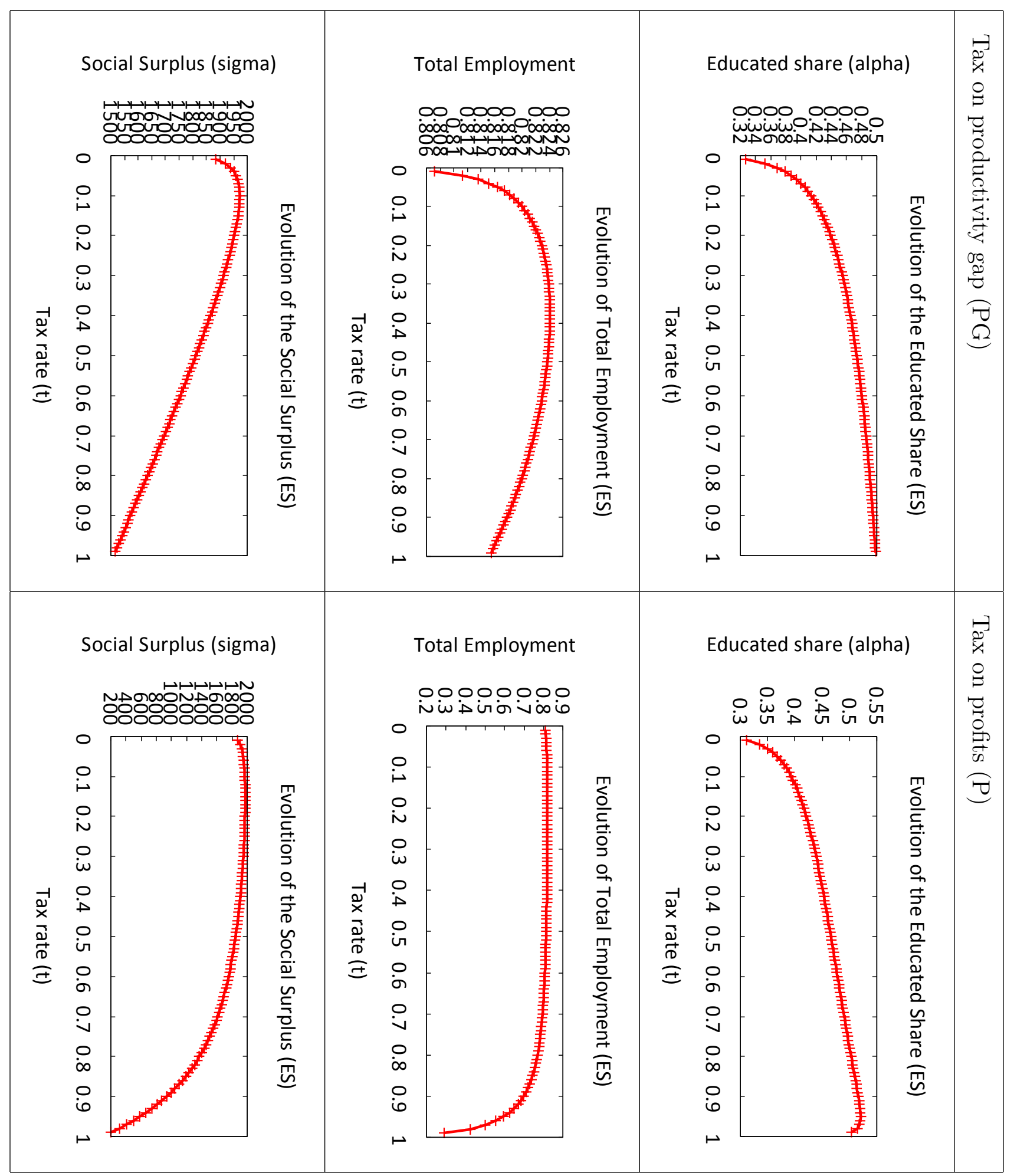


Table 8: Tax rate impact: W scenario, Spain (ES)

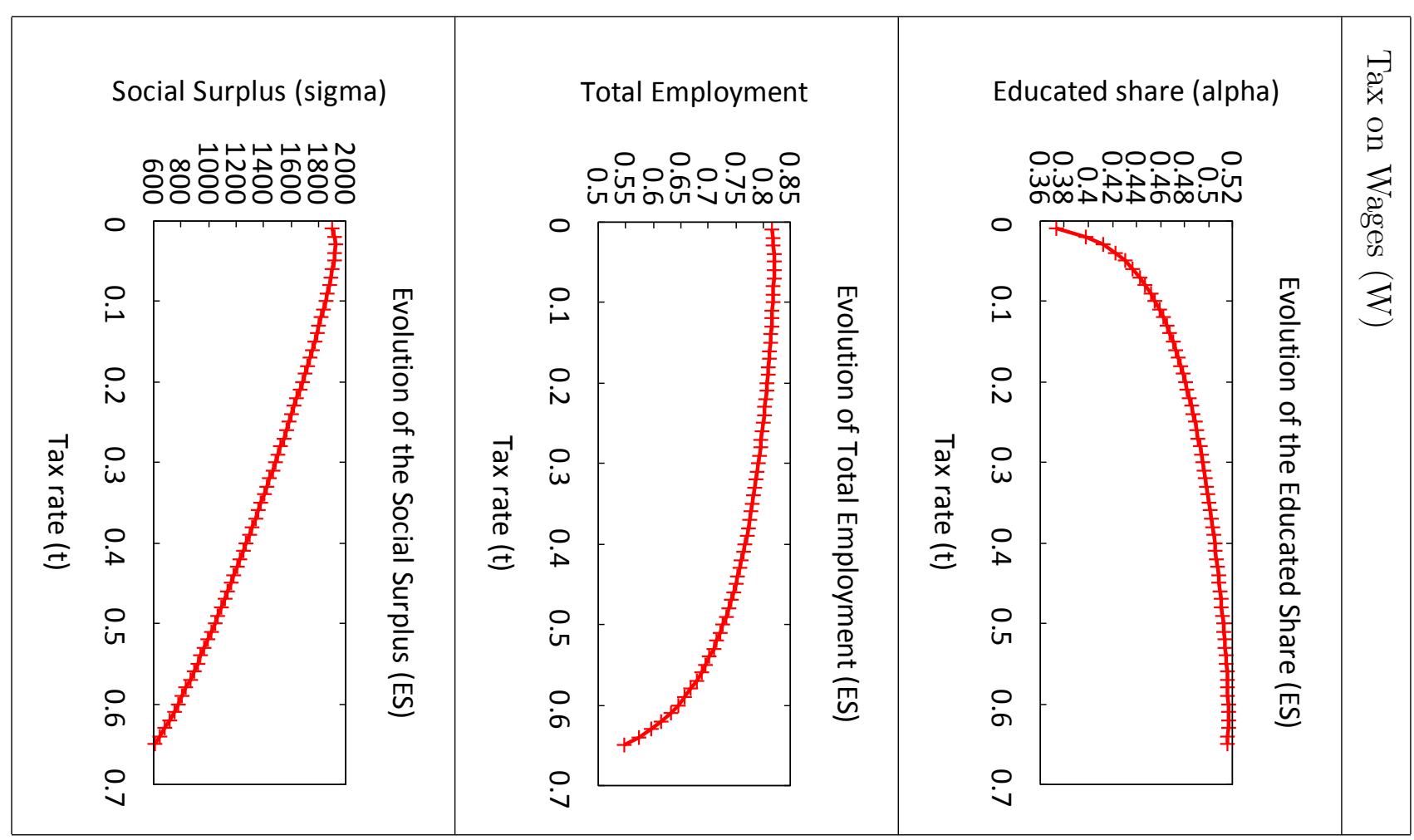


Table 9: Tax rate impact: $\mathrm{PG}$ and $\mathrm{P}$ scenarios, Finland (FI)

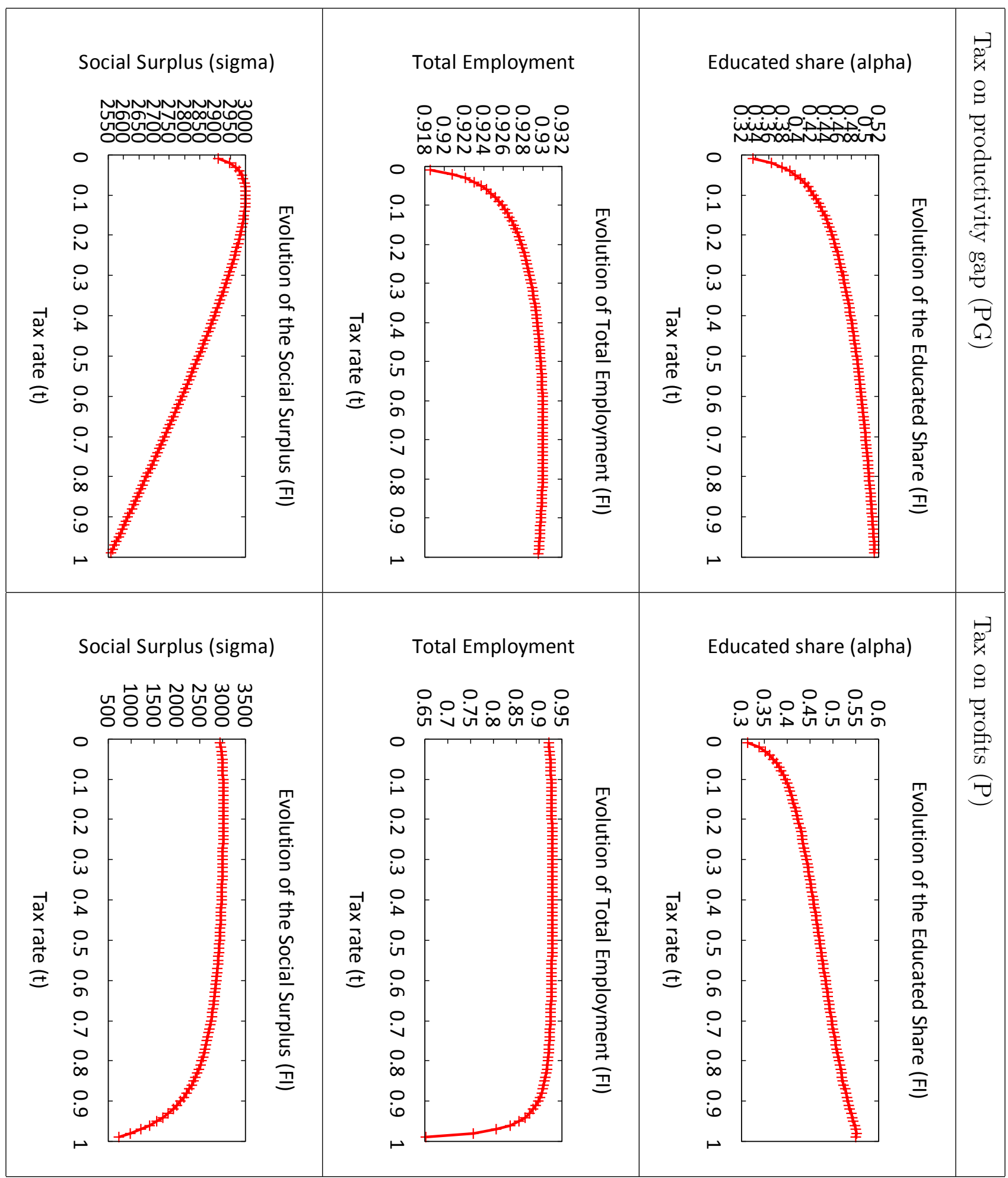


Table 10: Tax rate impact: W scenario, Finland (FI)

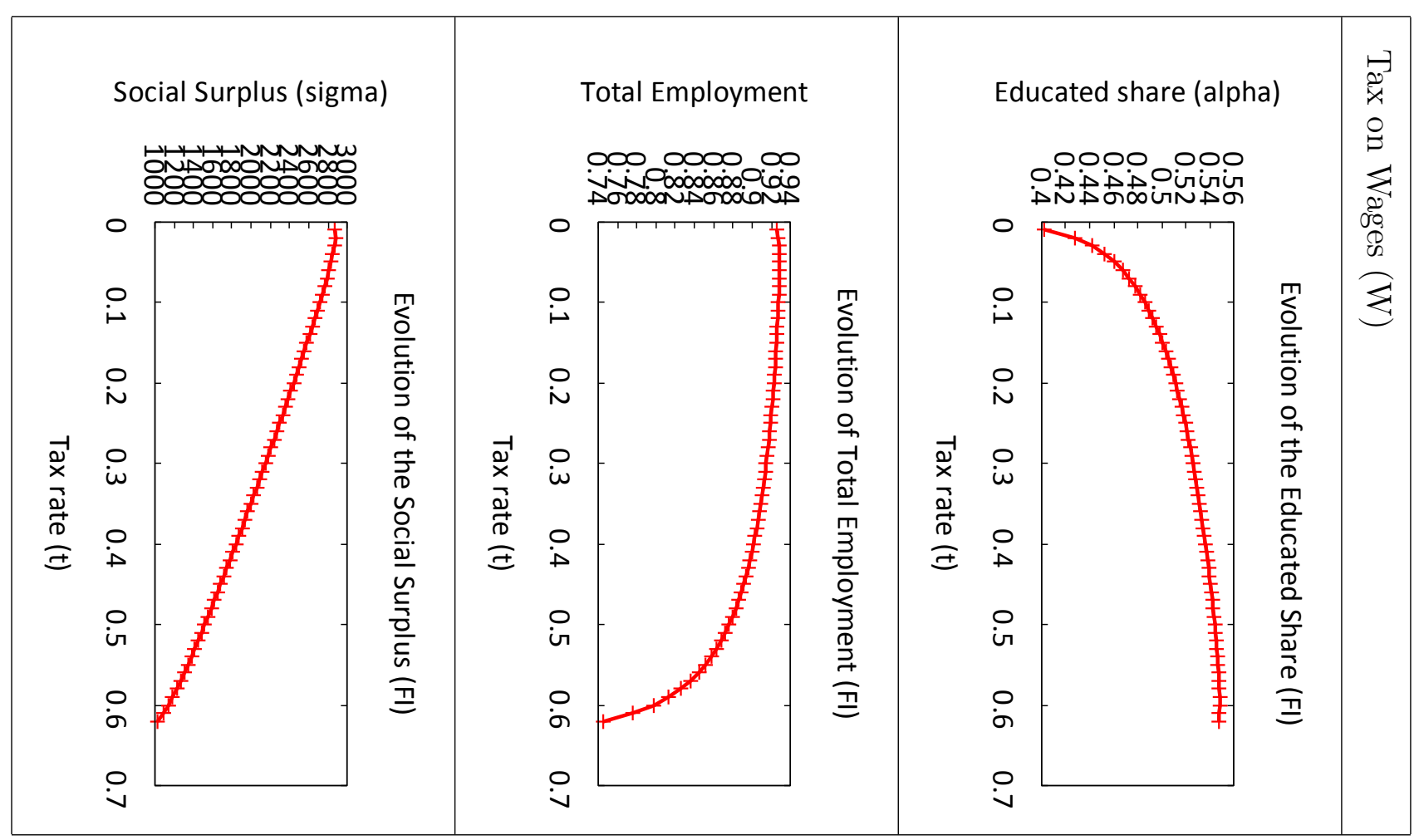


Table 11: Tax rate impact: $\mathrm{PG}$ and $\mathrm{P}$ scenarios, France (FR)

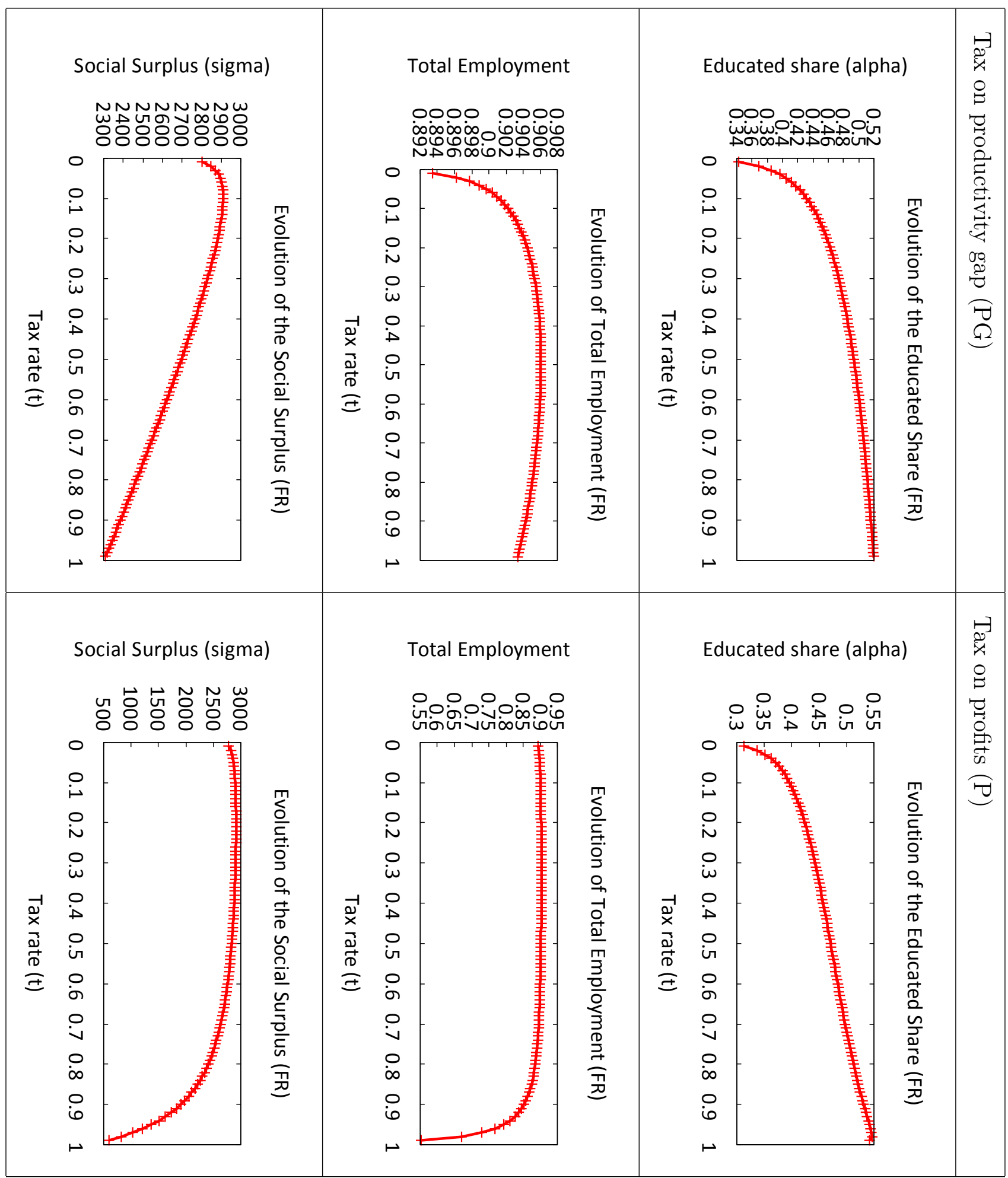


Table 12: Tax rate impact: W scenario, France (FR)

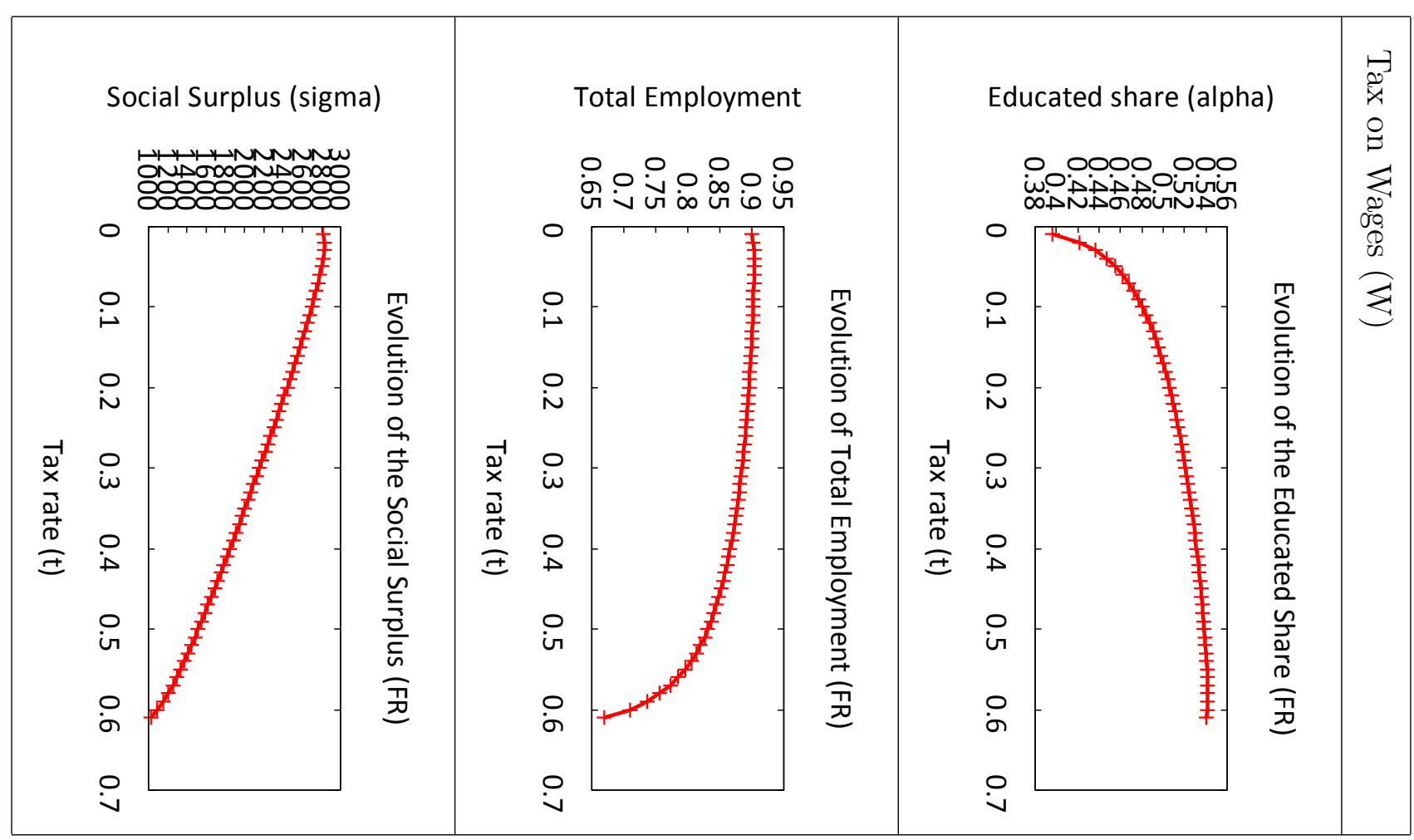


Table 13: Tax rate impact: PG and P scenarios, Greece (GR)

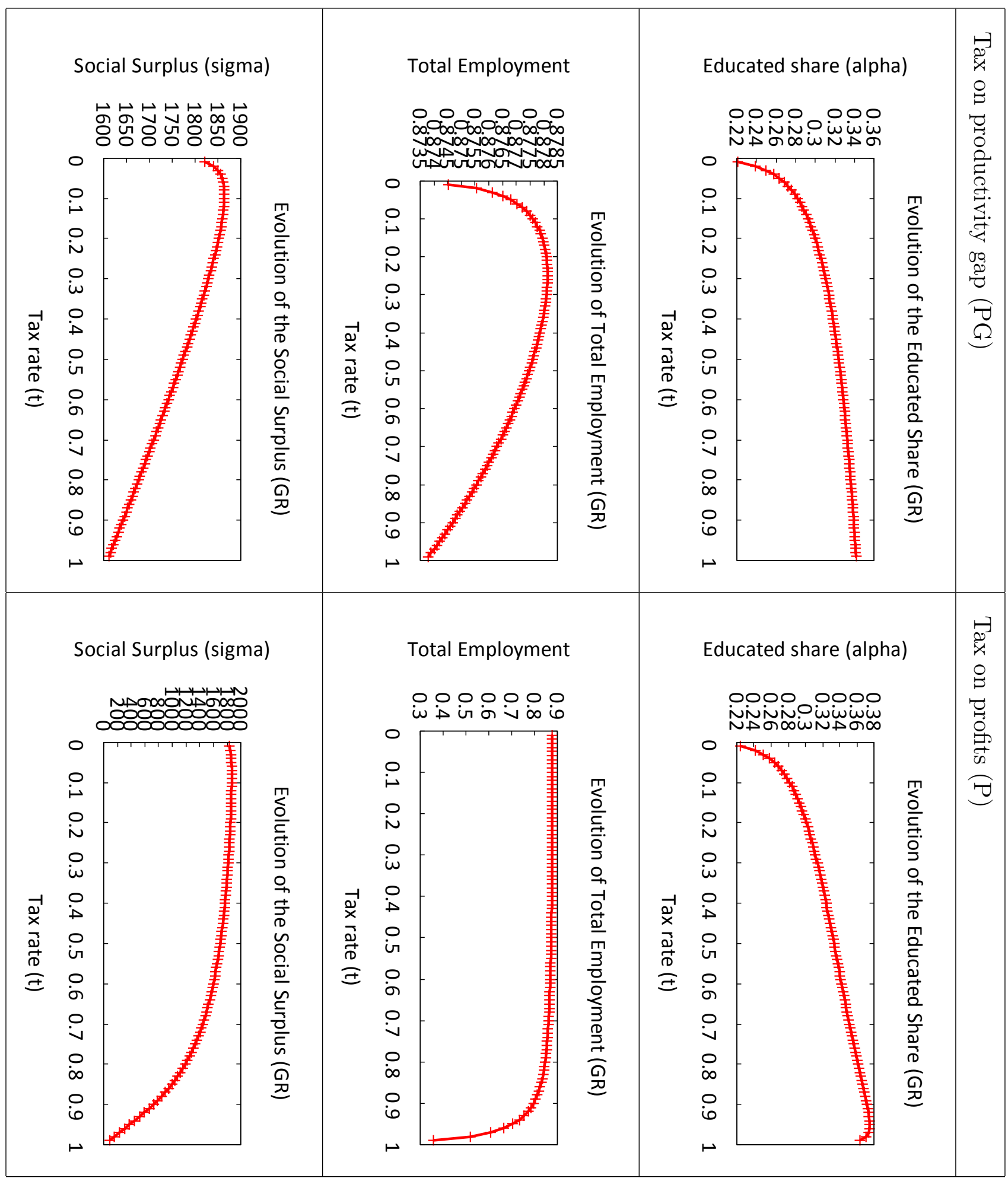


Table 14: Tax rate impact: W scenario, Greece (GR)

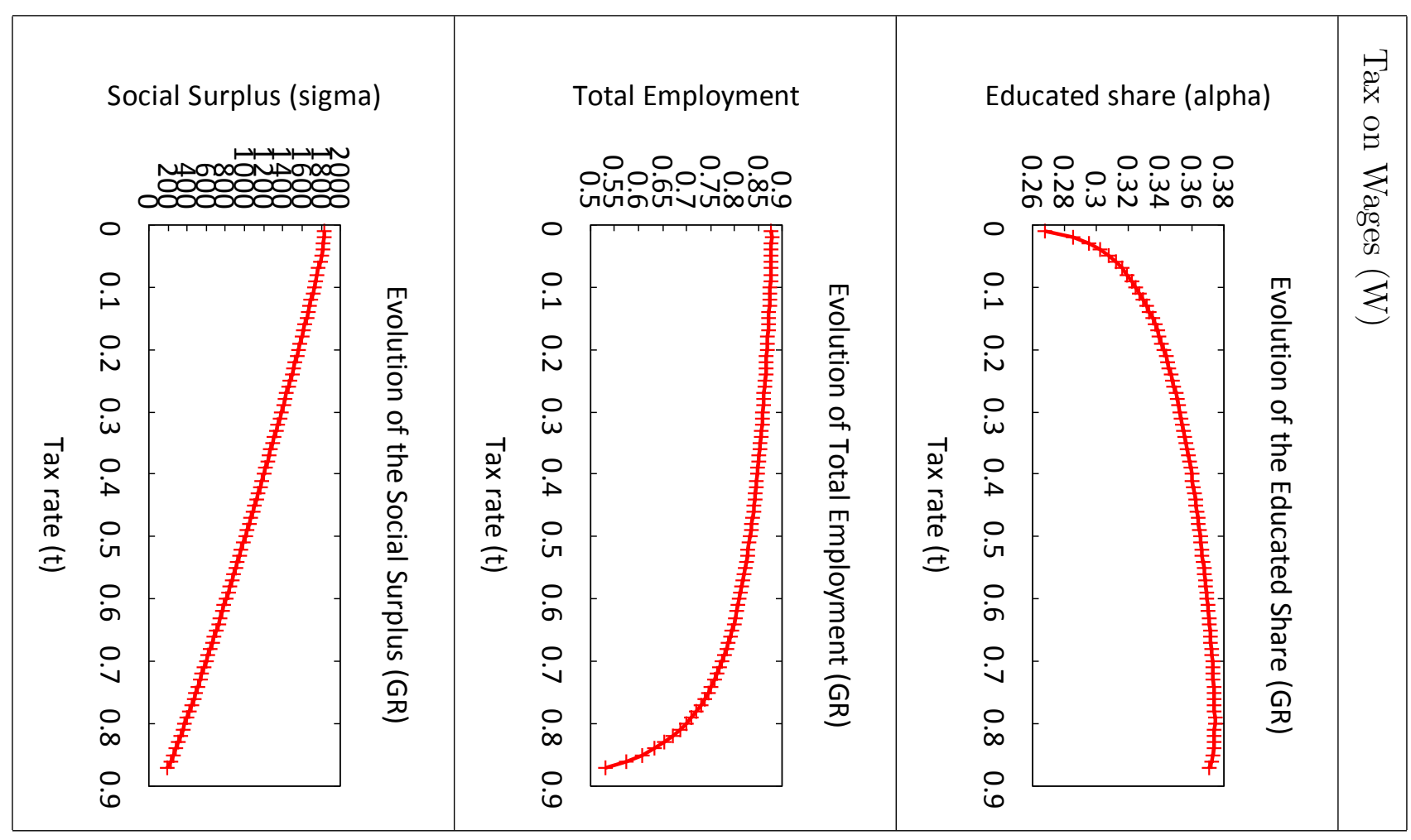


Table 15: Tax rate impact: PG and P scenarios, Hungary (HU)

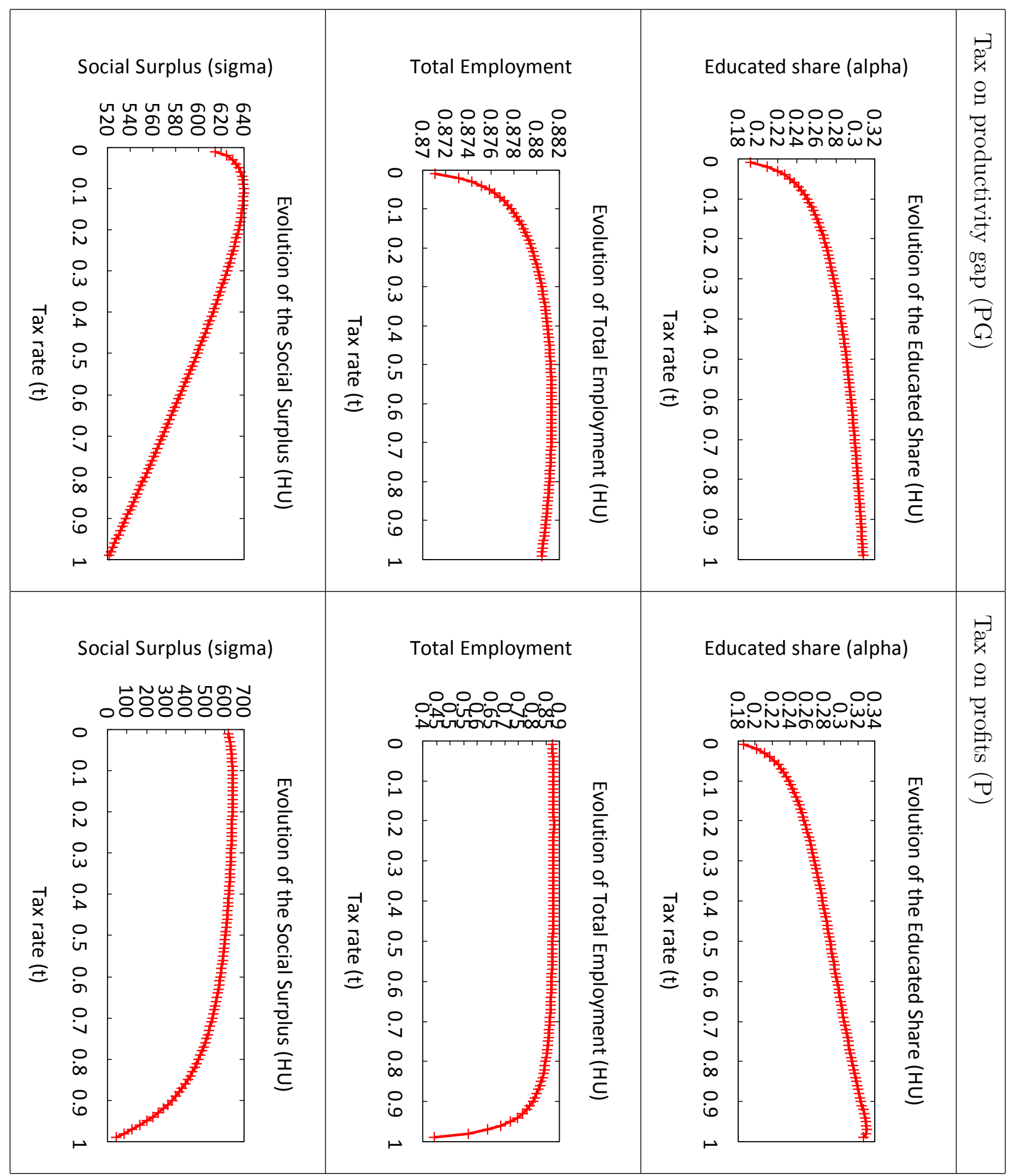


Table 16: Tax rate impact: W scenario, Hungary (HU)

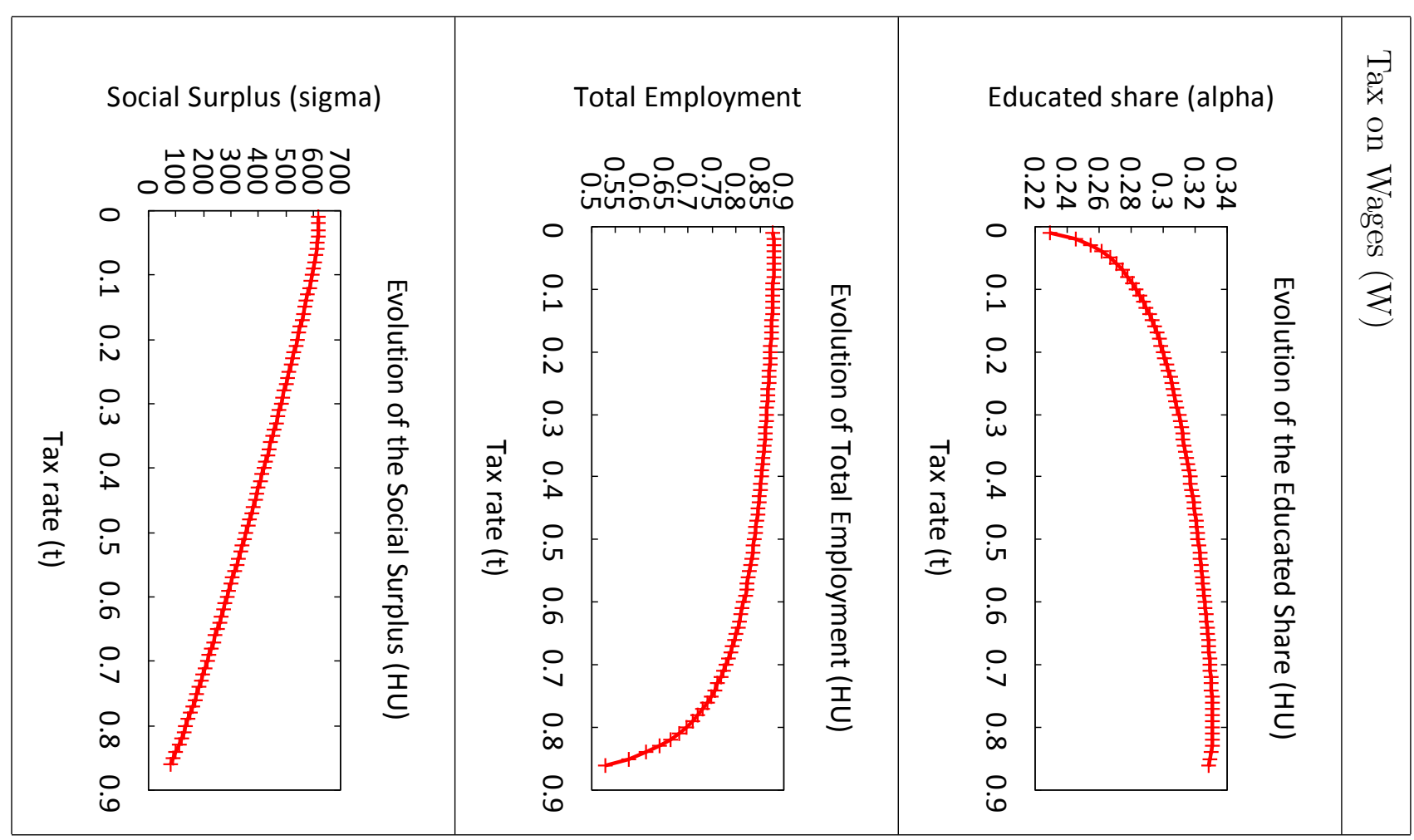


Table 17: Tax rate impact: PG and P scenarios, Italy (IT)

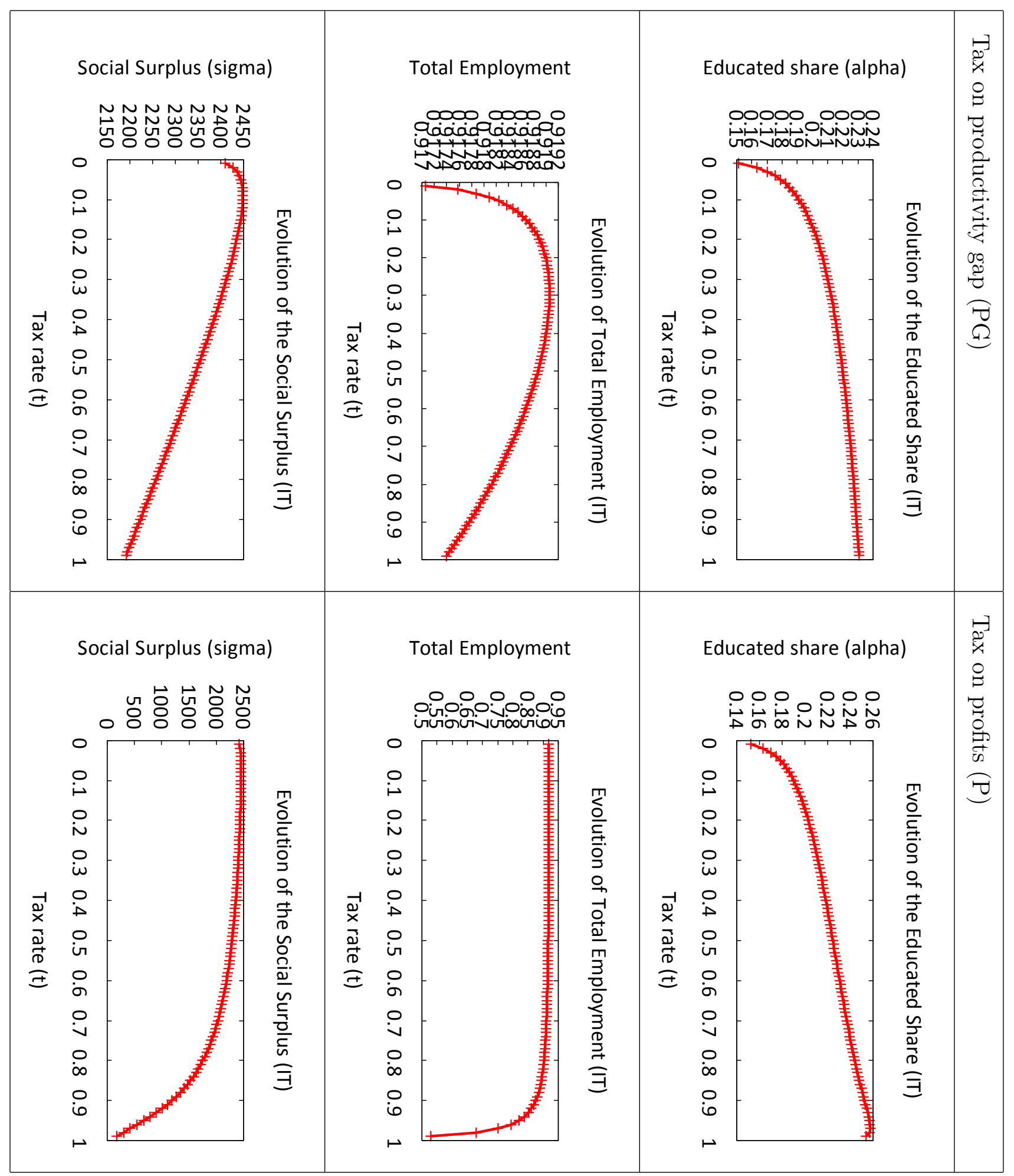


Table 18: Tax rate impact: W scenario, Italy (IT)

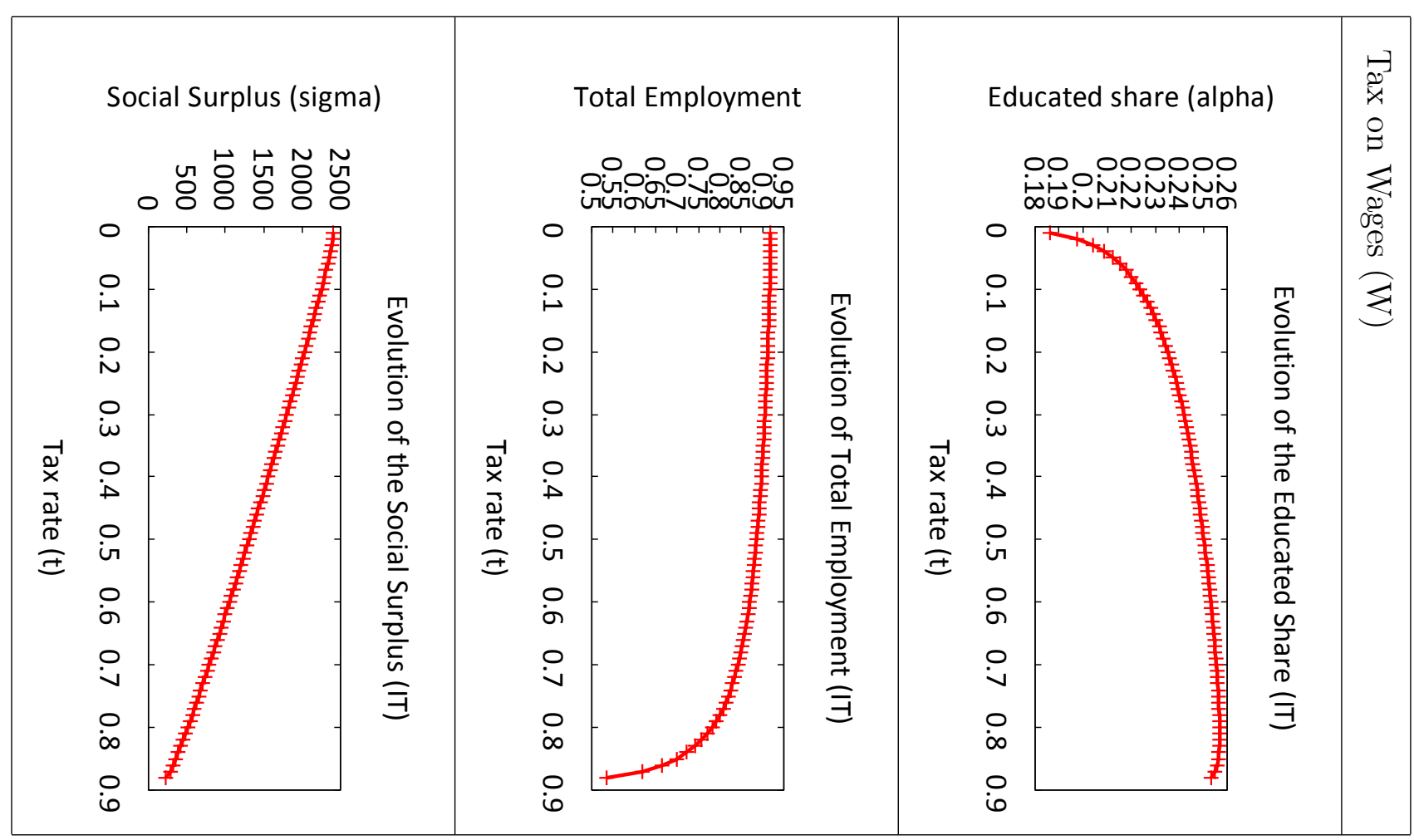


Table 19: Tax rate impact: PG and P scenarios, Luxembourg (LU)

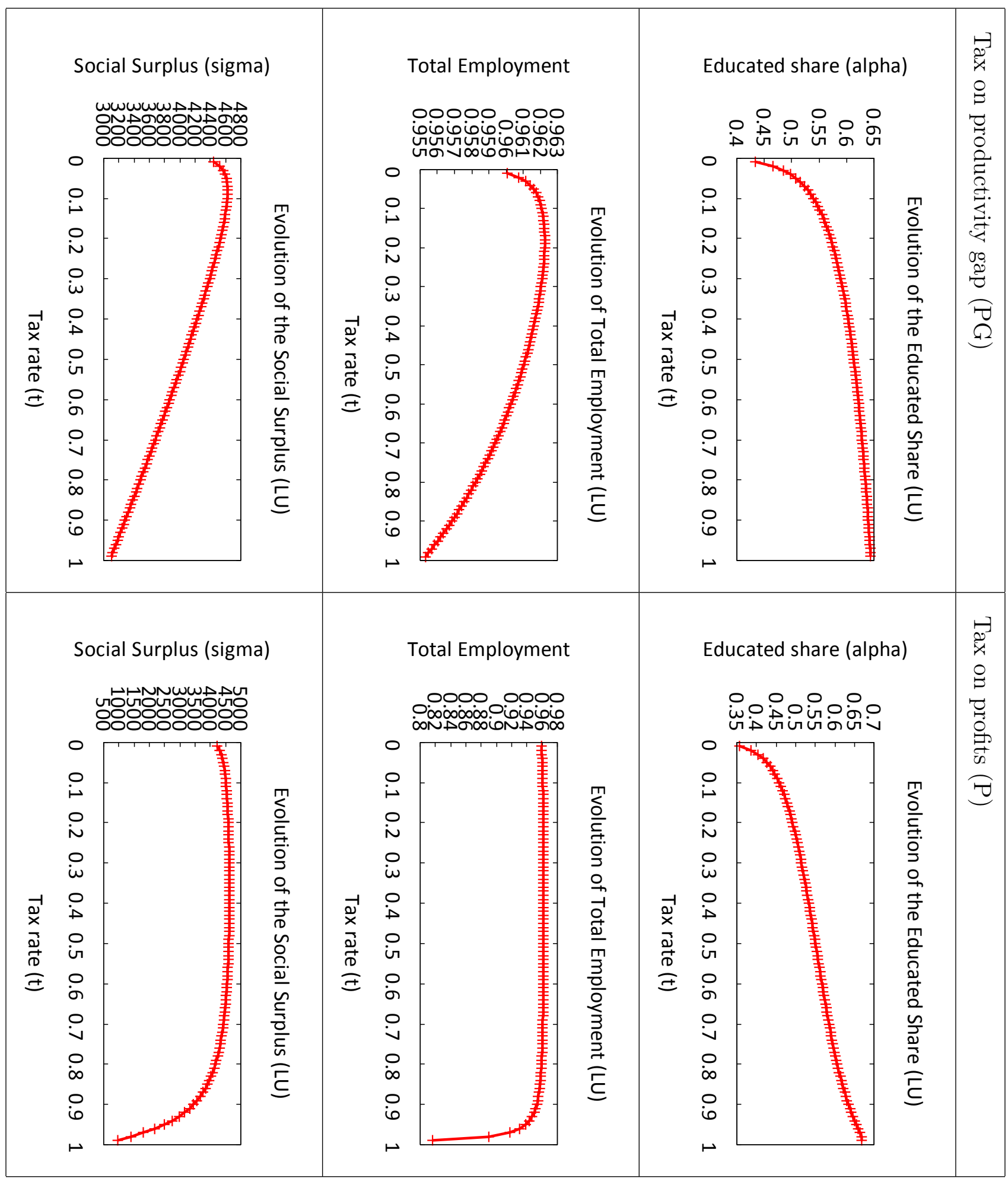


Table 20: Tax rate impact: W scenario, Luxembourg (LU)

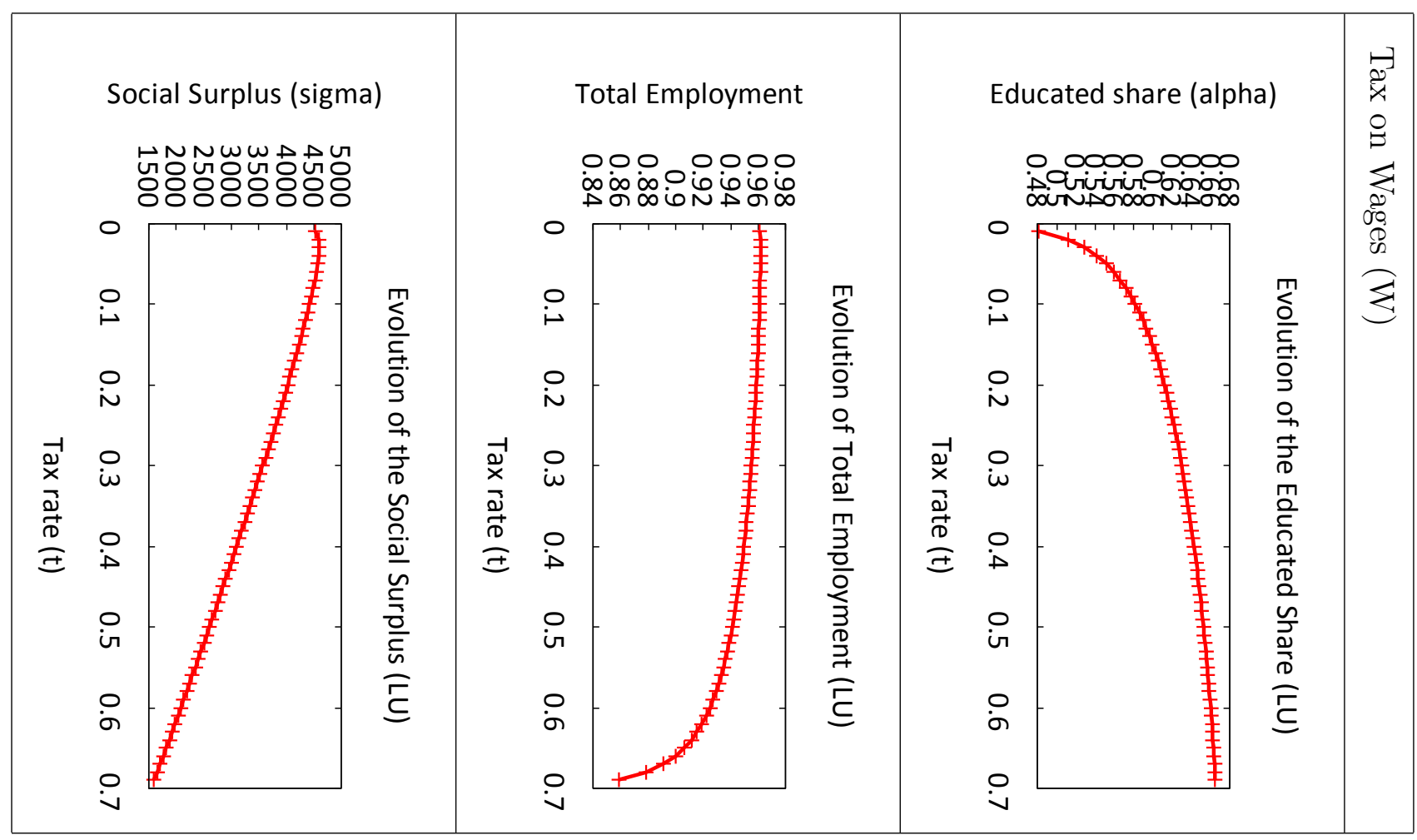


Table 21: Tax rate impact: PG and P scenarios, Netherlands (NL)

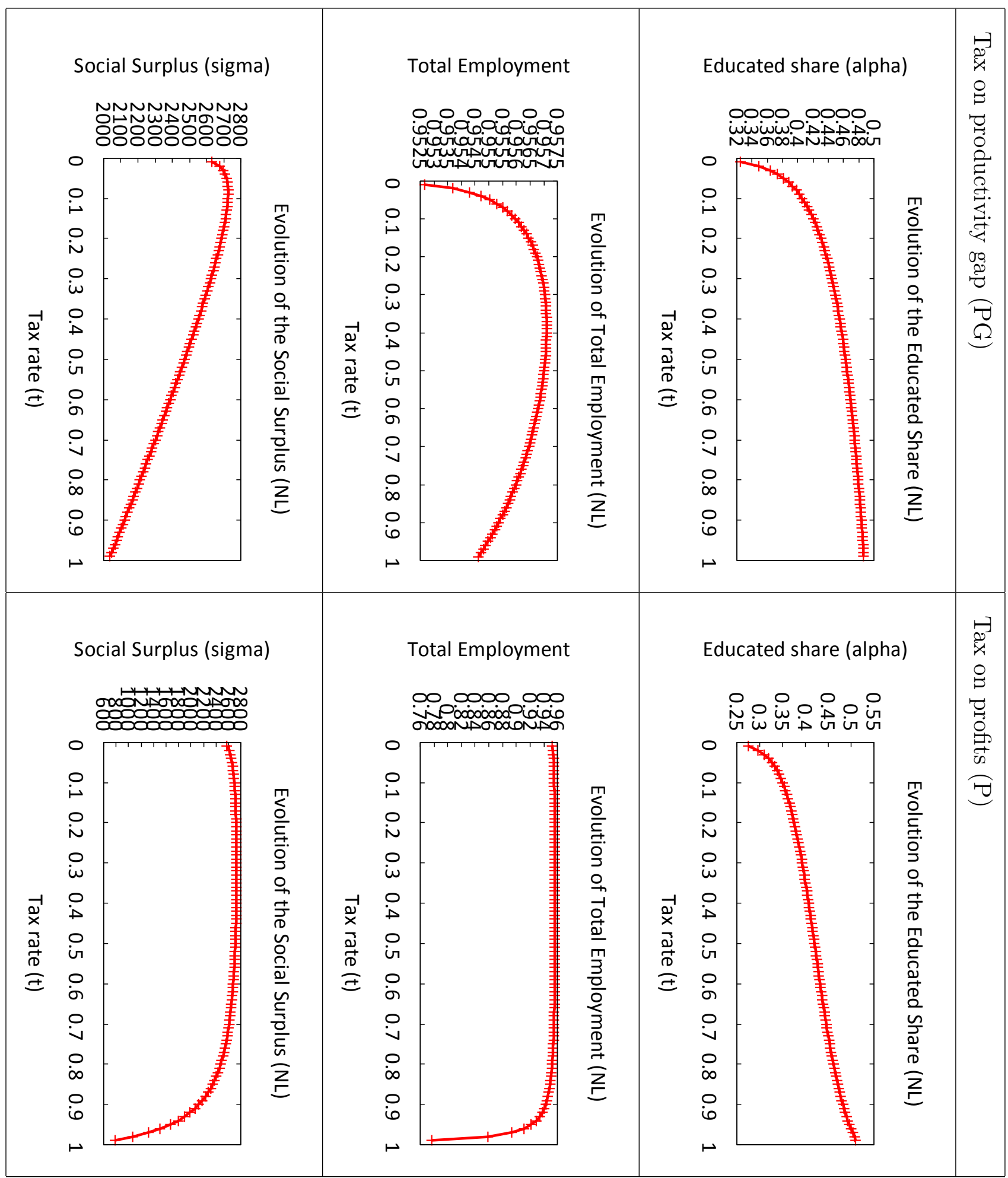


Table 22: Tax rate impact: W scenario, Netherlands (NL)

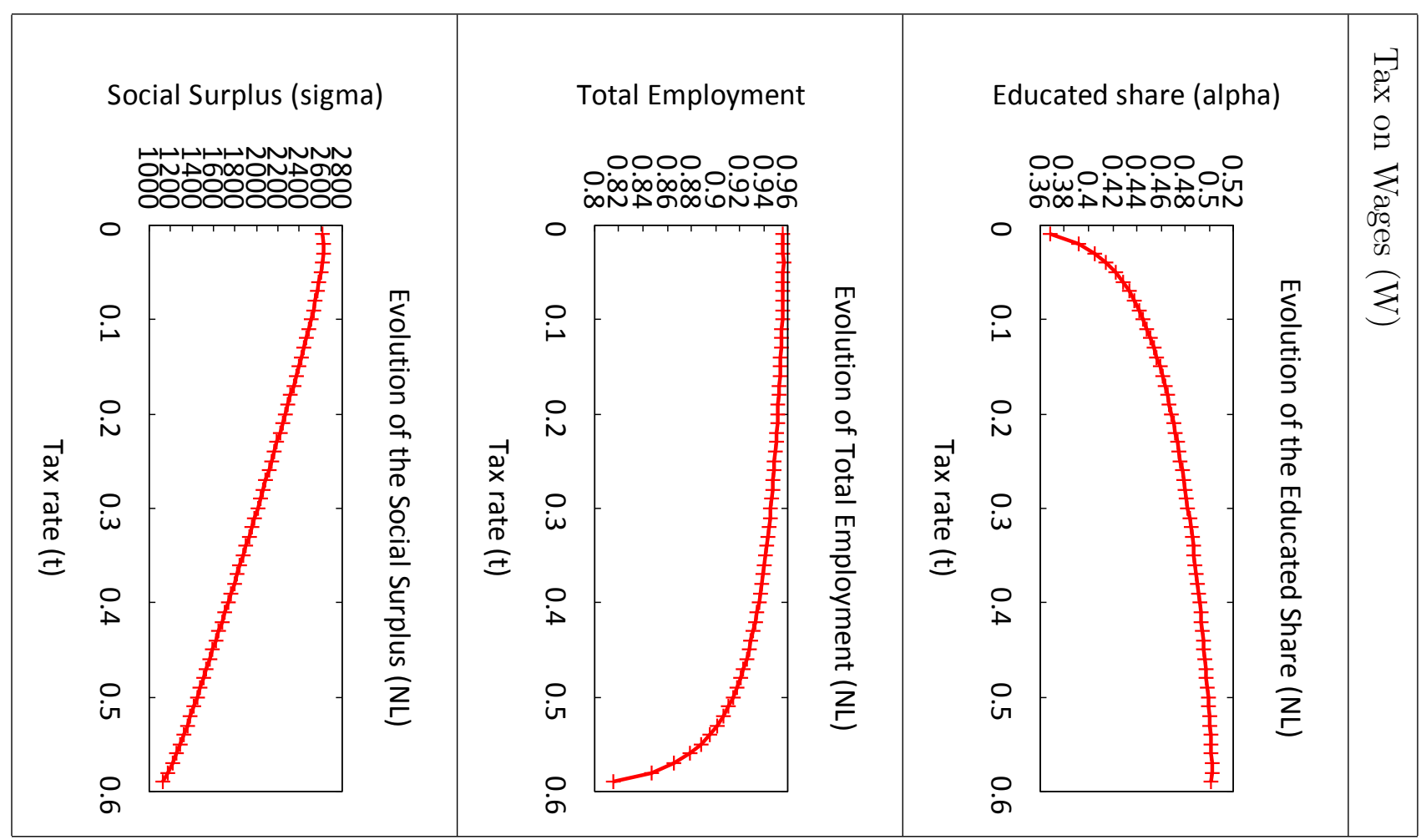


Table 23: Tax rate impact: $\mathrm{PG}$ and $\mathrm{P}$ scenarios, Poland (PL)

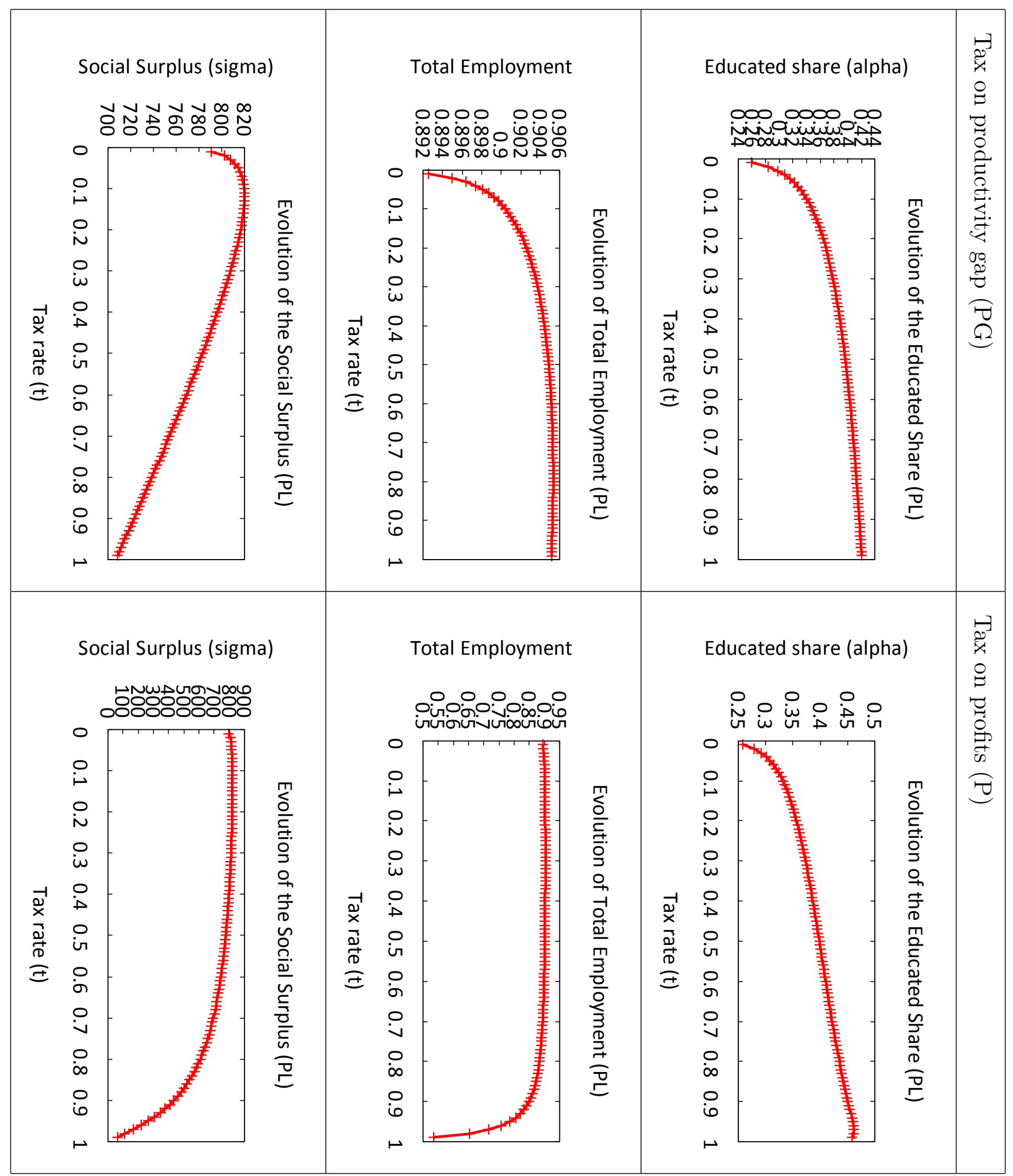


Table 24: Tax rate impact: W scenario, Poland (PL)

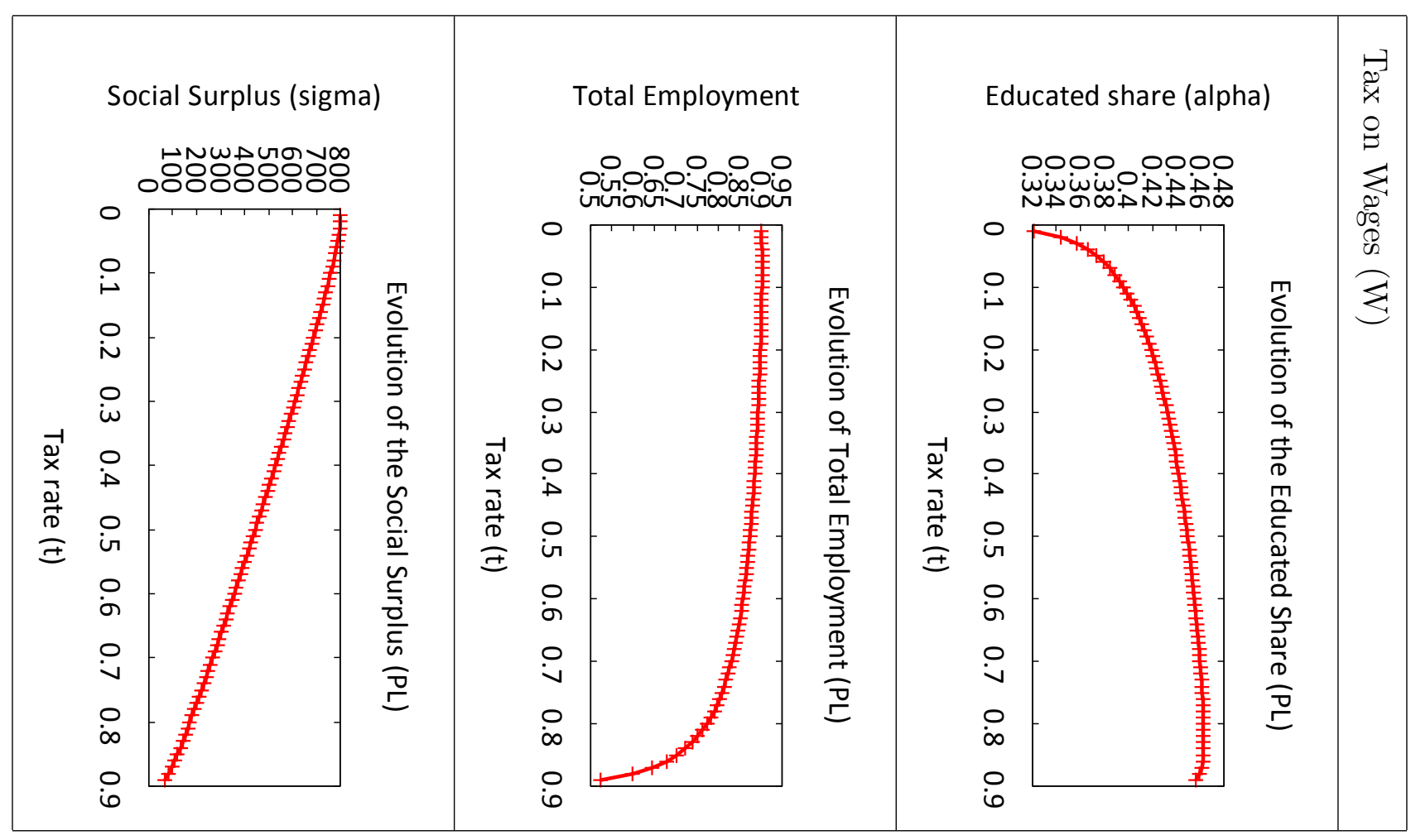


Table 25: Tax rate impact: PG and P scenarios, Portugal (PT)

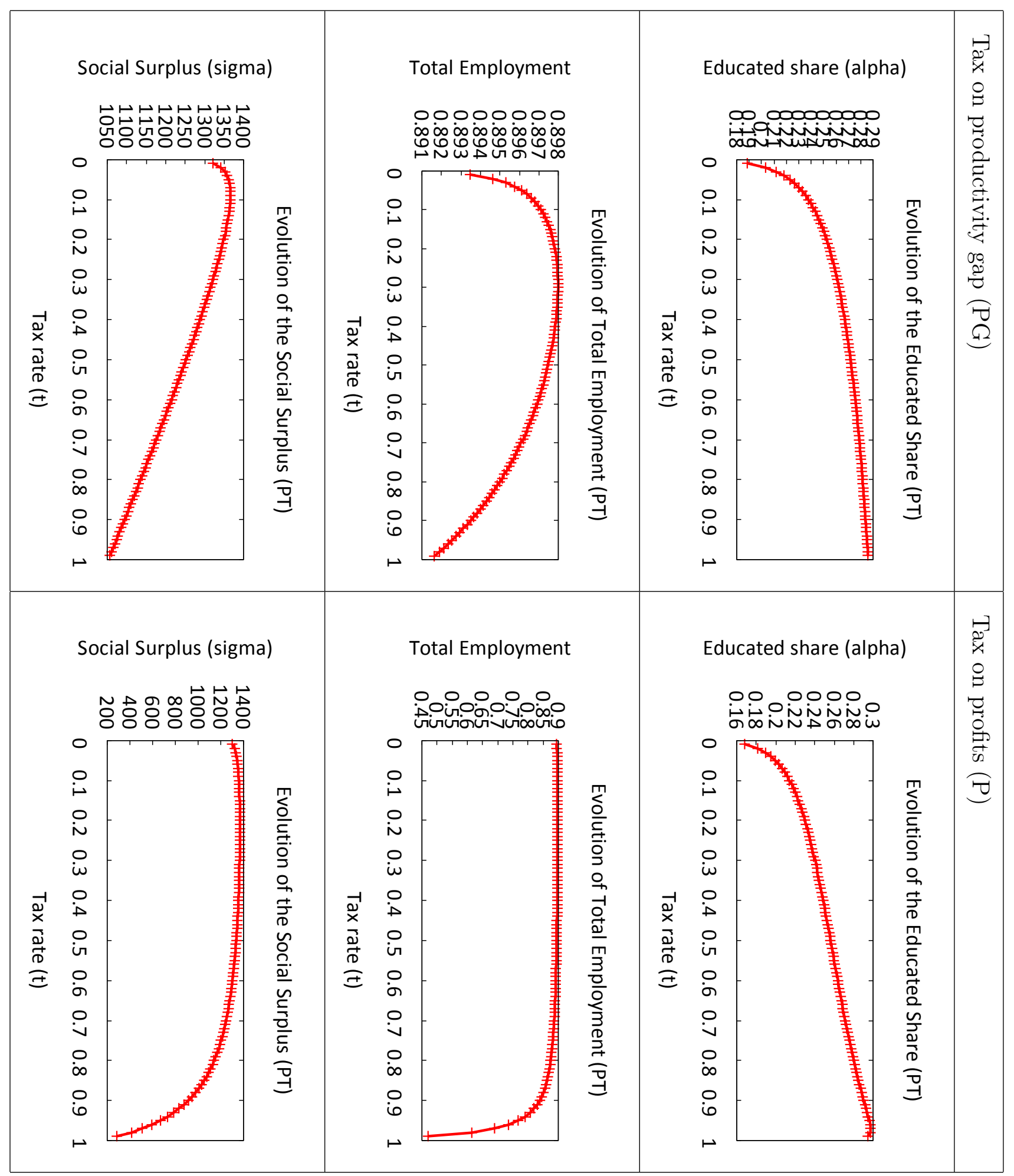


Table 26: Tax rate impact: W scenario, Portugal (PT)

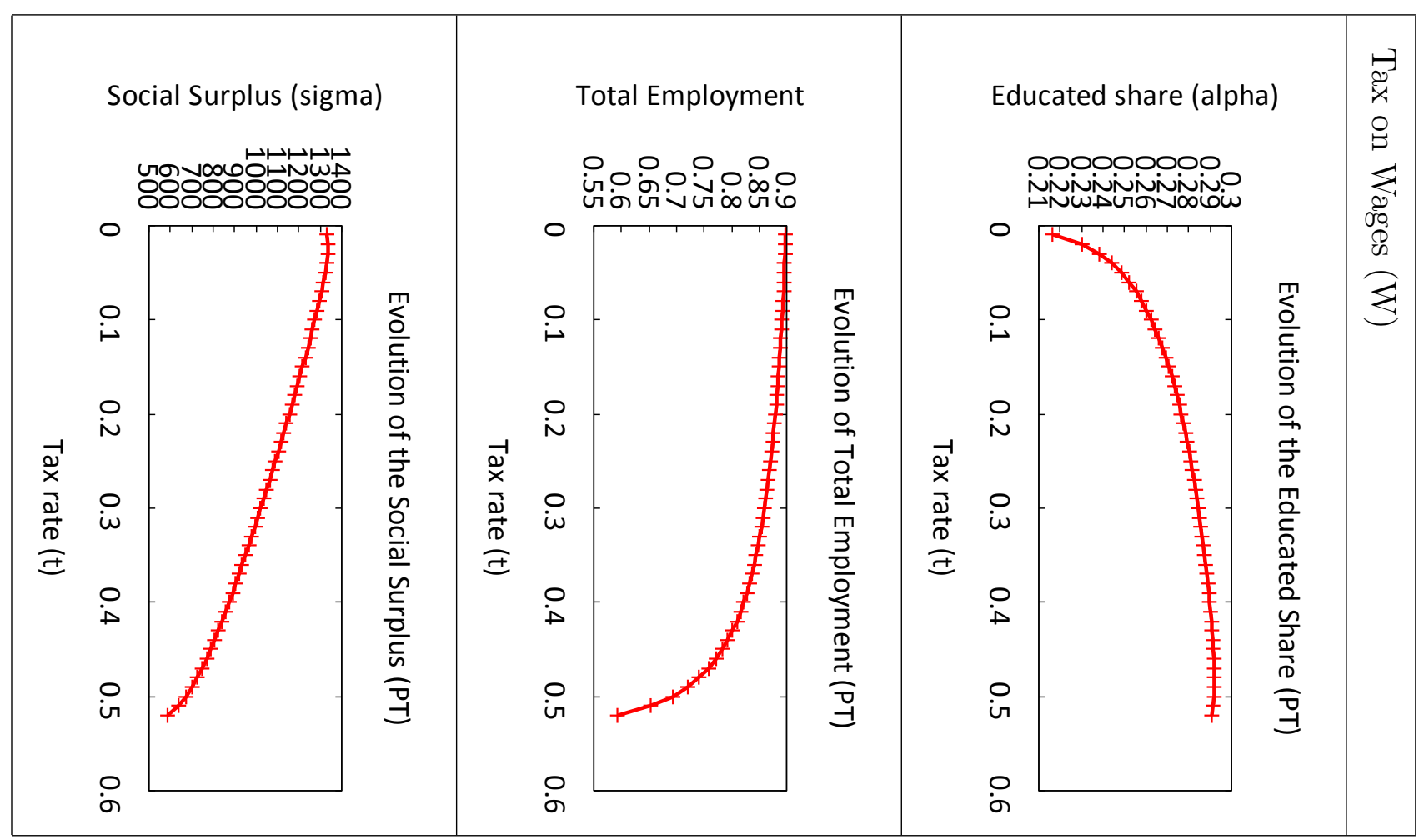


Table 27: Tax rate impact: PG and P scenarios, Sweden (SE)

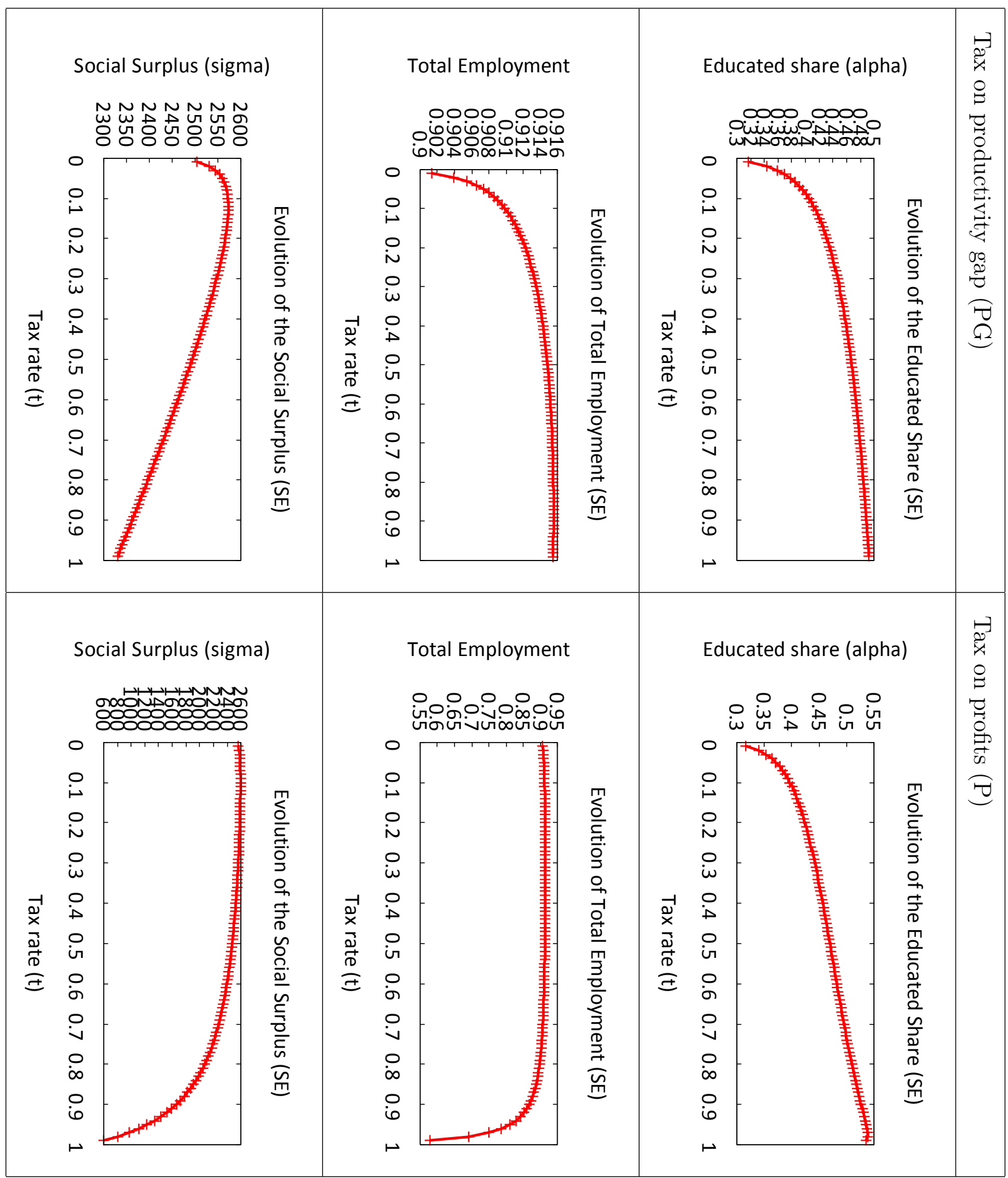


Table 28: Tax rate impact: W scenario, Sweden (SE)

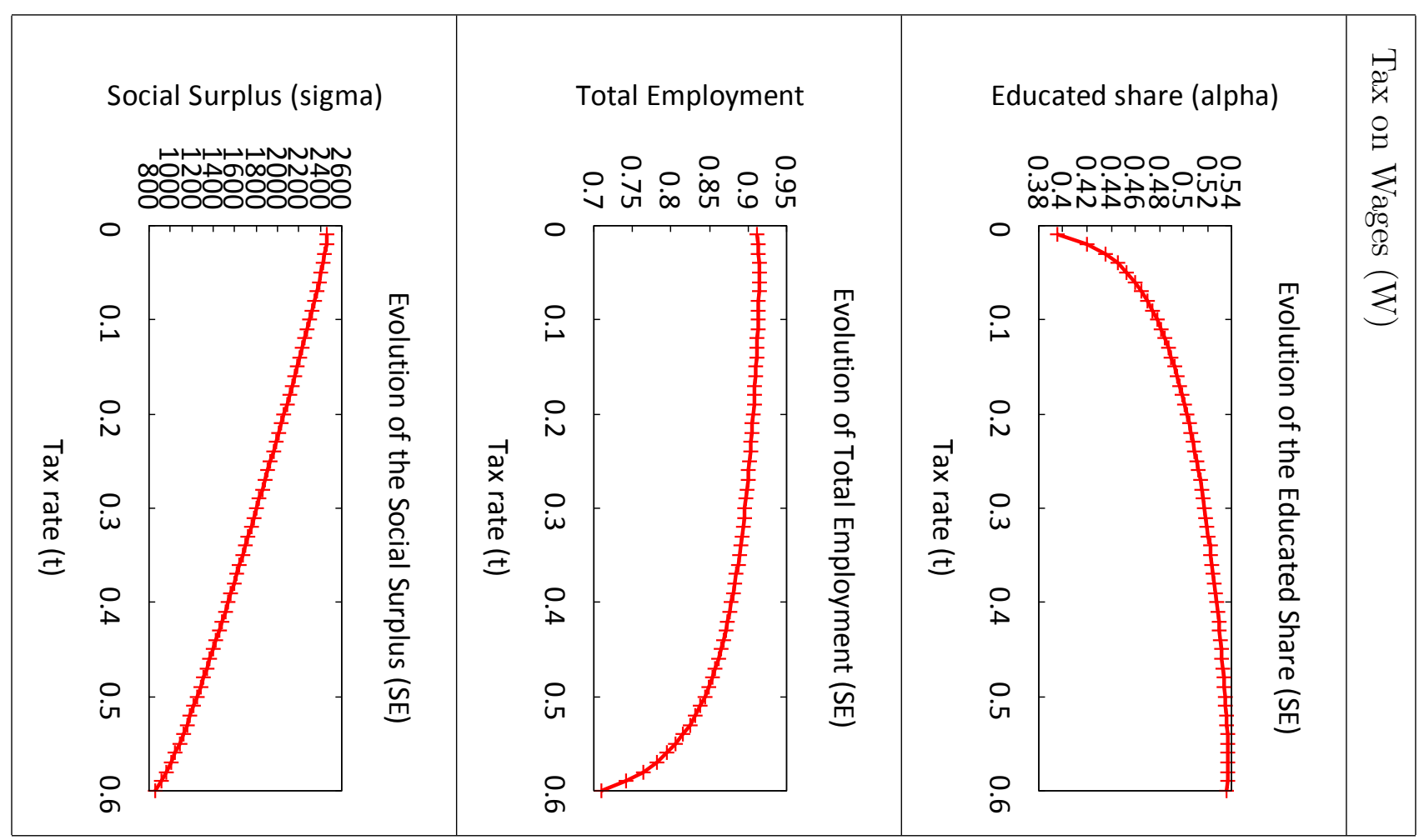


Table 29: Tax rate impact: PG and P scenarios, Slovakia (SK)

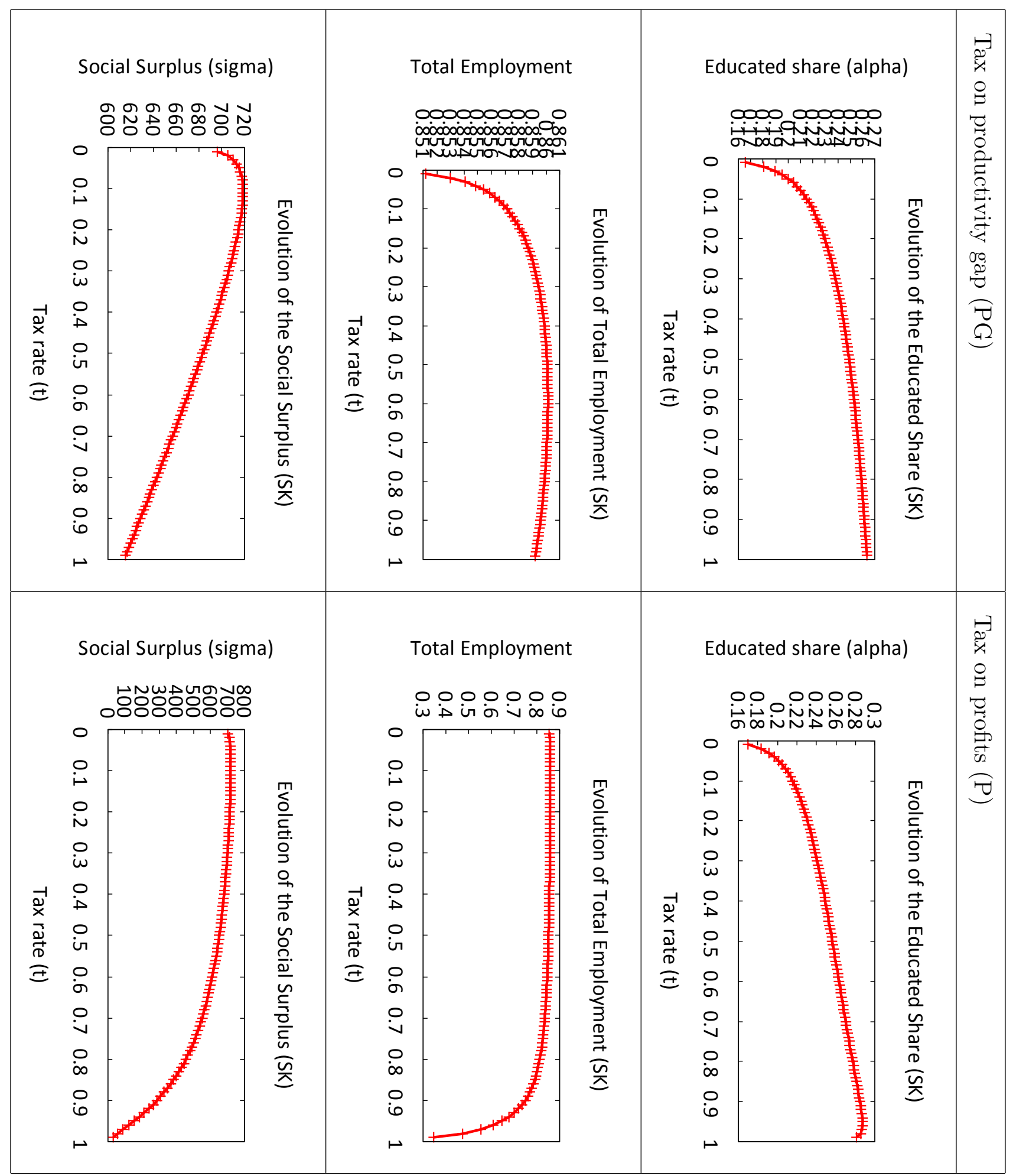


Table 30: Tax rate impact: W scenario, Slovakia (SK)

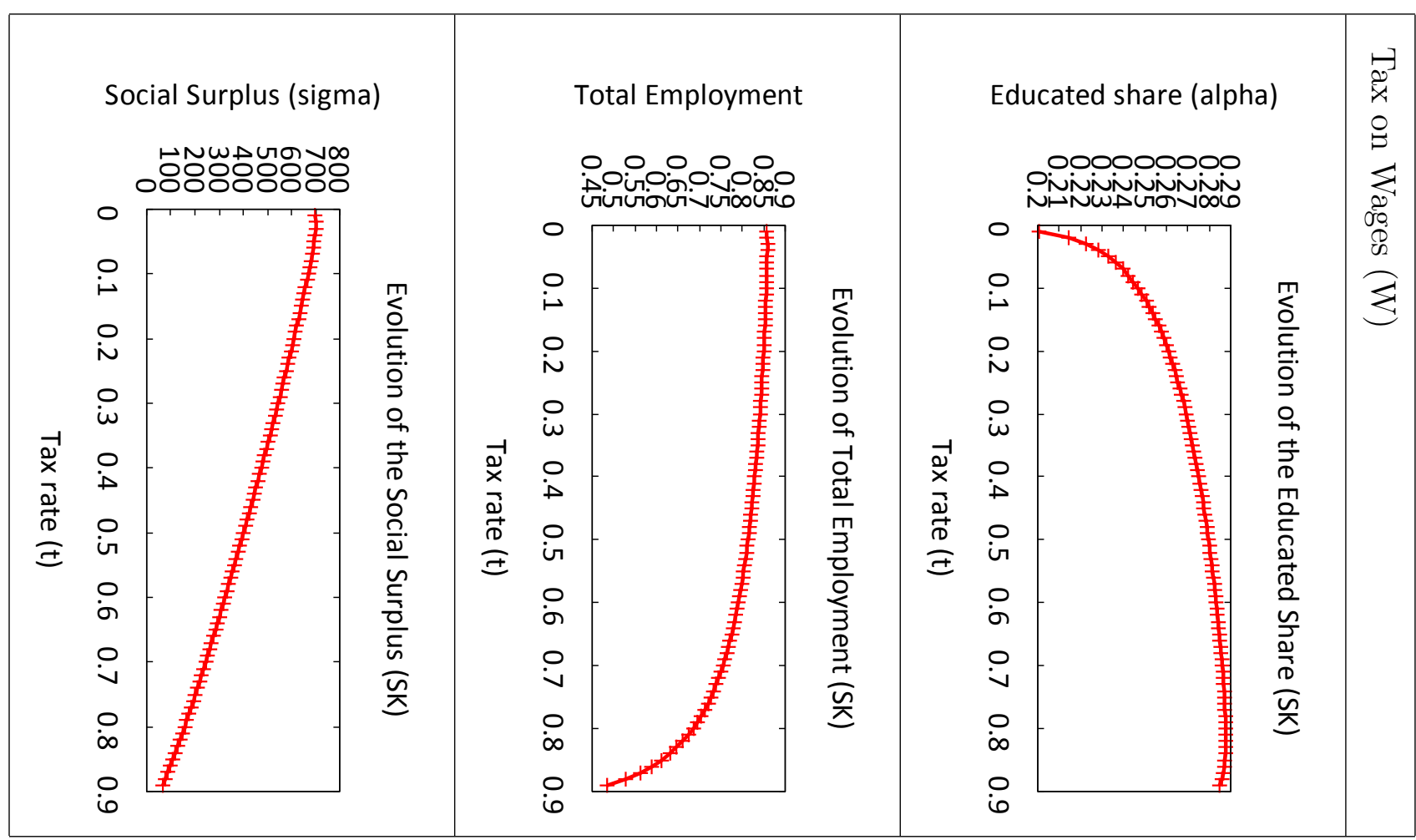

\section{A.4 Calibration results}


Table 31: Results for Belgium

\begin{tabular}{|c|c|c|c|c|c|c|c|c|c|c|c|c|}
\hline & \multicolumn{4}{|c|}{ Scenario Productivity Gap } & \multicolumn{4}{|c|}{ Scenario Profits } & \multicolumn{4}{|c|}{ Scenario Wages } \\
\hline & $\begin{array}{r}\text { Educated } \\
\text { Share }\end{array}$ & $\begin{array}{r}\text { Total } \\
\text { Employ. }\end{array}$ & $\begin{array}{r}\text { Social } \\
\text { Surplus }\end{array}$ & $\begin{array}{r}\text { Lisbon } \\
\text { target }\end{array}$ & \begin{tabular}{|r} 
Educated \\
Share
\end{tabular} & $\begin{array}{r}\text { Total } \\
\text { Employ. }\end{array}$ & $\begin{array}{r}\text { Social } \\
\text { Surplus }\end{array}$ & $\begin{array}{r}\text { Lisbon } \\
\text { target }\end{array}$ & \begin{tabular}{|} 
Educated \\
Share
\end{tabular} & $\begin{array}{r}\text { Total } \\
\text { Employ. }\end{array}$ & $\begin{array}{r}\text { Social } \\
\text { Surplus }\end{array}$ & $\begin{array}{r}\text { Lisbon } \\
\text { target }\end{array}$ \\
\hline$t$ & 0.99900 & 0.35000 & 0.08700 & 0.15500 & 0.97800 & 0.33100 & 0.25200 & 0.41400 & 0.57600 & 0.04500 & 0.02700 & 0.05300 \\
\hline$w_{1}$ & 2892.13 & 4544.35 & 5219.69 & 5044.85 & 1601.41 & 5193.52 & 5238.37 & 5134.19 & 5380.94 & 5242.66 & 5239.14 & 5244.24 \\
\hline$w_{2}$ & 2790.96 & 2790.96 & 2790.96 & 2790.96 & 1254.82 & 2750.82 & 2790.59 & 2699.26 & 2556.13 & 2429.89 & 2423.75 & 2432.63 \\
\hline$\ell_{1}$ & 0.50928 & 0.48011 & 0.42990 & 0.45113 & 0.49427 & 0.43960 & 0.42674 & 0.45135 & 0.51455 & 0.44527 & 0.42727 & 0.45101 \\
\hline$\ell_{2}$ & 0.40447 & 0.44002 & 0.48790 & 0.46801 & 0.22950 & 0.47815 & 0.49084 & 0.46621 & 0.25919 & 0.47257 & 0.49025 & 0.46679 \\
\hline$\ell$ & 0.91375 & 0.92013 & 0.91780 & 0.91914 & 0.72377 & 0.91775 & 0.91758 & 0.91756 & 0.77374 & 0.91784 & 0.91751 & 0.91780 \\
\hline$\alpha$ & 0.54197 & 0.50171 & 0.44748 & 0.47001 & 0.56247 & 0.45764 & 0.44415 & 0.47002 & 0.55562 & 0.46368 & 0.44472 & 0.46976 \\
\hline$\sigma$ & 2696.02 & 3524.67 & 3725.01 & 3700.75 & 1104.91 & 3717.05 & 3724.52 & 3693.32 & 1616.96 & 3612.69 & 3629.18 & 3598.93 \\
\hline
\end{tabular}

Table 32: Results for Czech Republic

\begin{tabular}{|c|c|c|c|c|c|c|c|c|c|c|c|c|}
\hline & \multicolumn{4}{|c|}{ Scenario Productivity Gap } & \multicolumn{4}{|c|}{ Scenario Profits } & \multicolumn{4}{|c|}{ Scenario Wages } \\
\hline & \begin{tabular}{|} 
Educated \\
Share
\end{tabular} & $\begin{array}{r}\text { Total } \\
\text { Employ. }\end{array}$ & $\begin{array}{r}\text { Social } \\
\text { Surplus }\end{array}$ & $\begin{array}{r}\text { Lisbon } \\
\text { target }\end{array}$ & \begin{tabular}{|} 
Educated \\
Share
\end{tabular} & $\begin{array}{r}\text { Total } \\
\text { Employ. }\end{array}$ & $\begin{array}{r}\text { Social } \\
\text { Surplus }\end{array}$ & $\begin{array}{r}\text { Lisbon } \\
\text { target }\end{array}$ & \begin{tabular}{|} 
Educated \\
Share
\end{tabular} & $\begin{array}{r}\text { Total } \\
\text { Employ. }\end{array}$ & $\begin{array}{r}\text { Social } \\
\text { Surplus }\end{array}$ & $\begin{array}{r}\text { Lisbon } \\
\text { target }\end{array}$ \\
\hline$t$ & 0.99900 & 0.59500 & 0.09700 & & 0.97800 & 0.20700 & 0.12900 & & 0.59900 & 0.03100 & 0.01600 & \\
\hline$w_{1}$ & 850.32 & 1161.61 & 1546.77 & & 359.18 & 1507.08 & 1513.77 & & 1528.09 & 1505.82 & 1505.35 & \\
\hline$w_{2}$ & 796.08 & 796.08 & 796.08 & & 98.41 & 798.20 & 808.45 & & 783.53 & 719.39 & 718.04 & \\
\hline$\ell_{1}$ & 0.23255 & 0.22419 & 0.19164 & & 0.25029 & 0.19818 & 0.18885 & & 0.24913 & 0.20087 & 0.18957 & \\
\hline$\ell_{2}$ & 0.69382 & 0.70264 & 0.73372 & & 0.48527 & 0.72766 & 0.73685 & & 0.63884 & 0.72491 & 0.73601 & \\
\hline$\ell$ & 0.92637 & 0.92683 & 0.92535 & & 0.73556 & 0.92584 & 0.92569 & & 0.88796 & 0.92577 & 0.92557 & \\
\hline$\alpha$ & 0.23952 & 0.22986 & 0.19580 & & 0.26269 & 0.20255 & 0.19299 & & 0.25798 & 0.20530 & 0.19371 & \\
\hline$\sigma$ & 780.54 & 851.29 & 913.14 & & 144.28 & 912.06 & 914.40 & & 403.99 & 885.65 & 889.65 & \\
\hline
\end{tabular}


Table 33: Results for Spain

\begin{tabular}{|c|c|c|c|c|c|c|c|c|c|c|c|c|}
\hline & \multicolumn{4}{|c|}{ Scenario Productivity Gap } & \multicolumn{4}{|c|}{ Scenario Profits } & \multicolumn{4}{|c|}{ Scenario Wages } \\
\hline & $\begin{array}{r}\text { Educated } \\
\text { Share }\end{array}$ & $\begin{array}{r}\text { Total } \\
\text { Employ. }\end{array}$ & $\begin{array}{r}\text { Social } \\
\text { Surplus }\end{array}$ & $\begin{array}{r}\text { Lisbon } \\
\text { target }\end{array}$ & \begin{tabular}{|r} 
Educated \\
Share
\end{tabular} & $\begin{array}{r}\text { Total } \\
\text { Employ. }\end{array}$ & $\begin{array}{r}\text { Social } \\
\text { Surplus }\end{array}$ & $\begin{array}{r}\text { Lisbon } \\
\text { target }\end{array}$ & \begin{tabular}{|} 
Educated \\
Share
\end{tabular} & $\begin{array}{r}\text { Total } \\
\text { Employ. }\end{array}$ & $\begin{array}{r}\text { Social } \\
\text { Surplus }\end{array}$ & $\begin{array}{r}\text { Lisbon } \\
\text { target }\end{array}$ \\
\hline$t$ & 0.99900 & 0.37600 & 0.10100 & 0.20400 & 0.95000 & 0.22100 & 0.15400 & 0.30900 & 0.61600 & 0.04800 & 0.02800 & 0.06500 \\
\hline$w_{1}$ & 1811.67 & 2628.11 & 2993.14 & 2856.16 & 1033.84 & 2981.67 & 3011.82 & 2934.09 & 3186.46 & 3023.07 & 3018.89 & 3026.68 \\
\hline$w_{2}$ & 1698.62 & 1698.62 & 1698.62 & 1698.62 & 742.19 & 1665.98 & 1693.10 & 1624.24 & 1676.96 & 1398.06 & 1390.47 & 1404.60 \\
\hline$\ell_{1}$ & 0.43611 & 0.41811 & 0.37684 & 0.39970 & 0.41040 & 0.38705 & 0.37367 & 0.40041 & 0.42731 & 0.39069 & 0.37358 & 0.40017 \\
\hline$\ell_{2}$ & 0.37907 & 0.40598 & 0.44315 & 0.42322 & 0.18453 & 0.43262 & 0.44556 & 0.41864 & 0.19479 & 0.42909 & 0.44548 & 0.41932 \\
\hline$\ell$ & 0.81518 & 0.82409 & 0.81999 & 0.82292 & 0.59493 & 0.81966 & 0.81923 & 0.81904 & 0.62210 & 0.81978 & 0.81906 & 0.81949 \\
\hline$\alpha$ & 0.49843 & 0.46283 & 0.41364 & 0.44001 & 0.52013 & 0.42494 & 0.41000 & 0.44005 & 0.51641 & 0.42926 & 0.40997 & 0.44014 \\
\hline$\sigma$ & 1509.22 & 1876.88 & 1972.22 & 1951.31 & 583.79 & 1965.61 & 1971.24 & 1944.38 & 729.75 & 1914.78 & 1924.40 & 1897.75 \\
\hline
\end{tabular}

Table 34: Results for Finland

\begin{tabular}{|c|c|c|c|c|c|c|c|c|c|c|c|c|}
\hline & \multicolumn{4}{|c|}{ Scenario Productivity Gap } & \multicolumn{4}{|c|}{ Scenario Profits } & \multicolumn{4}{|c|}{ Scenario Wages } \\
\hline & $\begin{array}{r}\text { Educated } \\
\text { Share }\end{array}$ & $\begin{array}{r}\text { Total } \\
\text { Employ. }\end{array}$ & $\begin{array}{r}\text { Social } \\
\text { Surplus }\end{array}$ & $\begin{array}{r}\text { Lisbon } \\
\text { target }\end{array}$ & $\begin{array}{r}\text { Educated } \\
\text { Share }\end{array}$ & $\begin{array}{r}\text { Total } \\
\text { Employ. }\end{array}$ & $\begin{array}{r}\text { Social } \\
\text { Surplus }\end{array}$ & $\begin{array}{r}\text { Lisbon } \\
\text { target }\end{array}$ & $\begin{array}{r}\text { Educated } \\
\text { Share }\end{array}$ & $\begin{array}{r}\text { Total } \\
\text { Employ. }\end{array}$ & $\begin{array}{r}\text { Social } \\
\text { Surplus }\end{array}$ & $\begin{array}{r}\text { Lisbon } \\
\text { target }\end{array}$ \\
\hline$t$ & 0.99900 & 0.76600 & 0.10200 & 0.08700 & 0.98200 & 0.37900 & 0.16900 & 0.18300 & 0.59800 & 0.05400 & 0.01600 & 0.01600 \\
\hline$w_{1}$ & 2738.85 & 3025.05 & 3843.72 & 3862.25 & 1332.36 & 3697.97 & 3753.92 & 3751.05 & 3765.68 & 3691.11 & 3687.42 & 3687.42 \\
\hline$w_{2}$ & 2585.61 & 2585.61 & 2585.61 & 2585.61 & 1068.65 & 2598.92 & 2696.68 & 2691.56 & 2616.64 & 2450.72 & 2441.10 & 2441.10 \\
\hline$\ell_{1}$ & 0.49716 & 0.48855 & 0.41512 & 0.40916 & 0.50870 & 0.44189 & 0.40563 & 0.40884 & 0.51542 & 0.45103 & 0.40841 & 0.40841 \\
\hline$\ell_{2}$ & 0.43241 & 0.44147 & 0.51079 & 0.51627 & 0.23293 & 0.48628 & 0.52140 & 0.51835 & 0.28586 & 0.47713 & 0.51821 & 0.51821 \\
\hline$\ell$ & 0.92957 & 0.93002 & 0.92591 & 0.92543 & 0.74163 & 0.92818 & 0.92702 & 0.92719 & 0.80128 & 0.92815 & 0.92663 & 0.92663 \\
\hline$\alpha$ & 0.51423 & 0.50404 & 0.42617 & 0.42001 & 0.55098 & 0.45398 & 0.41660 & 0.41991 & 0.54805 & 0.46347 & 0.41937 & 0.41937 \\
\hline$\sigma$ & 2553.03 & 2695.45 & 2999.96 & 2999.02 & 942.00 & 2980.37 & 3014.31 & 3014.13 & 1148.36 & 2822.15 & 2877.57 & 2877.57 \\
\hline
\end{tabular}


Table 35: Results for France

\begin{tabular}{|c|c|c|c|c|c|c|c|c|c|c|c|c|}
\hline & \multicolumn{4}{|c|}{ Scenario Productivity Gap } & \multicolumn{4}{|c|}{ Scenario Profits } & \multicolumn{4}{|c|}{ Scenario Wages } \\
\hline & $\begin{array}{r}\text { Educated } \\
\text { Share }\end{array}$ & $\begin{array}{r}\text { Total } \\
\text { Employ. }\end{array}$ & $\begin{array}{r}\text { Social } \\
\text { Surplus }\end{array}$ & $\begin{array}{r}\text { Lisbon } \\
\text { target }\end{array}$ & $\begin{array}{r}\text { Educated } \\
\text { Share }\end{array}$ & $\begin{array}{r}\text { Total } \\
\text { Employ. }\end{array}$ & $\begin{array}{r}\text { Social } \\
\text { Surplus }\end{array}$ & $\begin{array}{r}\text { Lisbon } \\
\text { target }\end{array}$ & $\begin{array}{r}\text { Educated } \\
\text { Share }\end{array}$ & $\begin{array}{r}\text { Total } \\
\text { Employ. }\end{array}$ & $\begin{array}{r}\text { Social } \\
\text { Surplus }\end{array}$ & $\begin{array}{r}\text { Lisbon } \\
\text { target }\end{array}$ \\
\hline$t$ & 0.99900 & 0.49700 & 0.09800 & 0.59600 & 7700 & 0.32400 & 0.20700 & 0.72000 & 0.58300 & 0.05000 & 0.02300 & 0.17000 \\
\hline$w_{1}$ & 2535.22 & 3348.24 & 3998.53 & 3187.37 & 1355.04 & 3953.39 & 3995.68 & 3578.90 & 4081.14 & 3982.41 & 3978.74 & 3999.72 \\
\hline$w_{2}$ & 2389.33 & 2389.33 & 2389.33 & 2389.33 & 1049.58 & 2356.24 & 2410.48 & 1945.96 & 2321.84 & 2144.35 & 2135.85 & 2183.91 \\
\hline$\ell_{1}$ & 0.49110 & 0.47115 & 0.41368 & 0.47699 & 0.48500 & 0.42848 & 0.40870 & 0.47879 & 0.49883 & 0.43695 & 0.41010 & 0.47808 \\
\hline$\ell_{2}$ & 0.41218 & 0.43493 & 0.48848 & 0.42897 & 0.20629 & 0.47425 & 0.49351 & 0.41488 & 0.25215 & 0.46602 & 0.49195 & 0.41946 \\
\hline$\ell$ & 0.90328 & 0.90608 & 0.90217 & 0.90596 & 0.69129 & 0.90272 & 0.90221 & 0.89368 & 0.75098 & 0.90298 & 0.90206 & 0.89754 \\
\hline$\alpha$ & 0.51957 & 0.49306 & 0.43064 & 0.50000 & 0.54583 & 0.44618 & 0.42546 & 0.50001 & 0.54155 & 0.45521 & 0.42692 & 0.50002 \\
\hline$\sigma$ & 2303.72 & 2698.97 & 2908.96 & 2626.05 & 890.77 & 2897.96 & 2910.82 & 2595.19 & 1190.88 & 2801.33 & 2829.09 & 2521.97 \\
\hline
\end{tabular}

Table 36: Results for Greece

\begin{tabular}{|c|c|c|c|c|c|c|c|c|c|c|c|c|}
\hline & \multicolumn{4}{|c|}{ Scenario Productivity Gap } & \multicolumn{4}{|c|}{ Scenario Profits } & \multicolumn{4}{|c|}{ Scenario Wages } \\
\hline & $\begin{array}{r}\text { Educated } \\
\text { Share }\end{array}$ & $\begin{array}{r}\text { Total } \\
\text { Employ. }\end{array}$ & $\begin{array}{r}\text { Social } \\
\text { Surplus }\end{array}$ & $\begin{array}{r}\text { Lisbon } \\
\text { target }\end{array}$ & $\begin{array}{r}\text { Educated } \\
\text { Share }\end{array}$ & $\begin{array}{r}\text { Total } \\
\text { Employ. }\end{array}$ & $\begin{array}{r}\text { Social } \\
\text { Surplus }\end{array}$ & $\begin{array}{r}\text { Lisbon } \\
\text { target }\end{array}$ & $\begin{array}{r}\text { Educated } \\
\text { Share }\end{array}$ & $\begin{array}{r}\text { Total } \\
\text { Employ. }\end{array}$ & $\begin{array}{r}\text { Social } \\
\text { Surplus }\end{array}$ & $\begin{array}{r}\text { Lisbon } \\
\text { target }\end{array}$ \\
\hline$t$ & 0.99900 & 0.24700 & 0.09400 & 0.43100 & 0.95200 & 0.12500 & 0.08500 & 0.35900 & 0.79700 & 0.02200 & 0.01500 & 0.08200 \\
\hline$w_{1}$ & 1774.07 & 2560.42 & 2721.64 & 2367.01 & 617.33 & 2699.36 & 2714.23 & 2578.88 & 2907.62 & 2706.07 & 2704.85 & 2716.71 \\
\hline$w_{2}$ & 1732.70 & 1732.70 & 1732.70 & 1732.70 & 382.82 & 1727.45 & 1740.41 & 1624.11 & 1850.41 & 1576.03 & 1574.36 & 1590.59 \\
\hline$\ell_{1}$ & 0.30636 & 0.27950 & 0.25702 & 0.29168 & 0.30120 & 0.26395 & 0.25456 & 0.29298 & 0.29881 & 0.26368 & 0.25514 & 0.29266 \\
\hline$\ell_{2}$ & 0.56734 & 0.59863 & 0.62052 & 0.58607 & 0.39628 & 0.61375 & 0.62304 & 0.58268 & 0.40378 & 0.61396 & 0.62241 & 0.58296 \\
\hline$\ell$ & 0.87370 & 0.87813 & 0.87754 & 0.87775 & 0.69748 & 0.87770 & 0.87760 & 0.87566 & 0.70259 & 0.87764 & 0.87754 & 0.87562 \\
\hline$\alpha$ & 0.34172 & 0.30541 & 0.28000 & 0.31998 & 0.37494 & 0.28767 & 0.27736 & 0.32001 & 0.37408 & 0.28740 & 0.27800 & 0.31991 \\
\hline$\sigma$ & 1608.18 & 1841.45 & 1863.64 & 1793.18 & 361.50 & 1861.66 & 1864.25 & 1788.63 & 385.24 & 1827.83 & 1830.32 & 1754.98 \\
\hline
\end{tabular}


Table 37: Results for Hungary

\begin{tabular}{|c|c|c|c|c|c|c|c|c|c|c|c|c|}
\hline & \multicolumn{4}{|c|}{ Scenario Productivity Gap } & \multicolumn{4}{|c|}{ Scenario Profits } & \multicolumn{4}{|c|}{ Scenario Wages } \\
\hline & \begin{tabular}{|r} 
Educated \\
Share
\end{tabular} & $\begin{array}{r}\text { Total } \\
\text { Employ. }\end{array}$ & $\begin{array}{r}\text { Social } \\
\text { Surplus }\end{array}$ & $\begin{array}{r}\text { Lisbon } \\
\text { target }\end{array}$ & \begin{tabular}{|r} 
Educated \\
Share
\end{tabular} & $\begin{array}{r}\text { Total } \\
\text { Employ. }\end{array}$ & $\begin{array}{r}\text { Social } \\
\text { Surplus }\end{array}$ & $\begin{array}{r}\text { Lisbon } \\
\text { target }\end{array}$ & \begin{tabular}{|} 
Educated \\
Share
\end{tabular} & $\begin{array}{r}\text { Total } \\
\text { Employ. }\end{array}$ & $\begin{array}{r}\text { Social } \\
\text { Surplus }\end{array}$ & $\begin{array}{r}\text { Lisbon } \\
\text { target }\end{array}$ \\
\hline$t$ & 0.99900 & 0.62000 & 0.10700 & 0.81700 & 0.97100 & 0.21100 & 0.14500 & 0.68700 & 0.79700 & 0.04400 & 0.02400 & 0.22900 \\
\hline$w_{1}$ & 600.63 & 811.39 & 1098.34 & 701.67 & 273.03 & 1084.38 & 1090.09 & 978.47 & 1122.14 & 1086.05 & 1085.40 & 1092.50 \\
\hline$w_{2}$ & 547.27 & 547.27 & 547.27 & 547.27 & 102.89 & 545.51 & 553.79 & 412.94 & 569.64 & 465.48 & 463.59 & 484.18 \\
\hline$\ell_{1}$ & 0.29334 & 0.28428 & 0.24357 & 0.28983 & 0.30485 & 0.24993 & 0.24017 & 0.29199 & 0.30227 & 0.25461 & 0.24091 & 0.29131 \\
\hline$\ell_{2}$ & 0.58703 & 0.59704 & 0.63436 & 0.59123 & 0.32681 & 0.62853 & 0.63805 & 0.57325 & 0.39813 & 0.62377 & 0.63705 & 0.57820 \\
\hline$\ell$ & 0.88037 & 0.88131 & 0.87793 & 0.88106 & 0.63166 & 0.87846 & 0.87823 & 0.86524 & 0.70040 & 0.87838 & 0.87795 & 0.86951 \\
\hline$\alpha$ & 0.30796 & 0.29617 & 0.25217 & 0.30301 & 0.33031 & 0.25881 & 0.24868 & 0.30298 & 0.33079 & 0.26372 & 0.24943 & 0.30304 \\
\hline$\sigma$ & 519.93 & 581.03 & 639.49 & 549.99 & 121.94 & 638.61 & 640.09 & 543.46 & 139.01 & 617.13 & 620.53 & 525.24 \\
\hline
\end{tabular}

Table 38: Results for Italy

\begin{tabular}{|c|c|c|c|c|c|c|c|c|c|c|c|c|}
\hline & \multicolumn{4}{|c|}{ Scenario Productivity Gap } & \multicolumn{4}{|c|}{ Scenario Profits } & \multicolumn{4}{|c|}{ Scenario Wages } \\
\hline & $\begin{array}{r}\text { Educated } \\
\text { Share }\end{array}$ & $\begin{array}{r}\text { Total } \\
\text { Employ. }\end{array}$ & $\begin{array}{r}\text { Social } \\
\text { Surplus }\end{array}$ & $\begin{array}{r}\text { Lisbon } \\
\text { target }\end{array}$ & $\begin{array}{r}\text { Educated } \\
\text { Share }\end{array}$ & $\begin{array}{r}\text { Total } \\
\text { Employ. }\end{array}$ & $\begin{array}{r}\text { Social } \\
\text { Surplus }\end{array}$ & $\begin{array}{r}\text { Lisbon } \\
\text { target }\end{array}$ & \begin{tabular}{|} 
Educated \\
Share
\end{tabular} & $\begin{array}{r}\text { Total } \\
\text { Employ. }\end{array}$ & $\begin{array}{r}\text { Social } \\
\text { Surplus }\end{array}$ & $\begin{array}{r}\text { Lisbon } \\
\text { target }\end{array}$ \\
\hline$t$ & 0.99900 & 0.29400 & 0.09000 & & 0.96900 & 0.12600 & 0.08200 & & 0.81100 & 0.01600 & 0.01000 & \\
\hline$w_{1}$ & 2333.61 & 3422.75 & 3739.61 & & 778.43 & 3657.32 & 3671.64 & & 3822.36 & 3646.78 & 3645.90 & \\
\hline$w_{2}$ & 2270.67 & 2270.67 & 2270.67 & & 441.40 & 2280.35 & 2294.20 & & 2375.15 & 2107.81 & 2106.45 & \\
\hline$\ell_{1}$ & 0.21714 & 0.19969 & 0.18057 & & 0.22698 & 0.18528 & 0.17808 & & 0.22505 & 0.18503 & 0.17784 & \\
\hline$\ell_{2}$ & 0.70021 & 0.71937 & 0.73805 & & 0.52974 & 0.73363 & 0.74076 & & 0.54448 & 0.73382 & 0.74095 & \\
\hline$\ell$ & 0.91735 & 0.91906 & 0.91862 & & 0.75672 & 0.91891 & 0.91884 & & 0.76953 & 0.91886 & 0.91879 & \\
\hline$\alpha$ & 0.23078 & 0.20973 & 0.18921 & & 0.25733 & 0.19426 & 0.18669 & & 0.25678 & 0.19400 & 0.18643 & \\
\hline$\sigma$ & 2188.29 & 2413.55 & 2448.48 & & 433.76 & 2447.94 & 2450.87 & & 479.67 & 2400.34 & 2403.06 & \\
\hline
\end{tabular}


Table 39: Results for Luxembourg

\begin{tabular}{|c|c|c|c|c|c|c|c|c|c|c|c|c|}
\hline & \multicolumn{4}{|c|}{ Scenario Productivity Gap } & \multicolumn{4}{|c|}{ Scenario Profits } & \multicolumn{4}{|c|}{ Scenario Wages } \\
\hline & $\begin{array}{r}\text { Educated } \\
\text { Share }\end{array}$ & $\begin{array}{r}\text { Total } \\
\text { Employ. }\end{array}$ & $\begin{array}{r}\text { Social } \\
\text { Surplus }\end{array}$ & $\begin{array}{r}\text { Lisbon } \\
\text { target }\end{array}$ & $\begin{array}{r}\text { Educated } \\
\text { Share }\end{array}$ & $\begin{array}{r}\text { Total } \\
\text { Employ. }\end{array}$ & $\begin{array}{r}\text { Social } \\
\text { Surplus }\end{array}$ & $\begin{array}{r}\text { Lisbon } \\
\text { target }\end{array}$ & $\begin{array}{r}\text { Educated } \\
\text { Share }\end{array}$ & $\begin{array}{r}\text { Total } \\
\text { Employ. }\end{array}$ & $\begin{array}{r}\text { Social } \\
\text { Surplus }\end{array}$ & $\begin{array}{r}\text { Lisbon } \\
\text { target }\end{array}$ \\
\hline$t$ & 0.99900 & 0.18100 & 0.08000 & 0.00500 & 0.98700 & 0.42300 & 0.37200 & 0.02800 & 0.68500 & 0.03900 & 0.02900 & 0.00200 \\
\hline$w_{1}$ & 3145.47 & 5734.11 & 6055.59 & 6294.49 & 1335.96 & 6090.04 & 6126.92 & 6277.39 & 6409.24 & 6258.22 & 6256.54 & 6252.08 \\
\hline$w_{2}$ & 3128.84 & 3128.84 & 3128.84 & 3128.84 & 1047.36 & 3021.55 & 3045.66 & 3145.30 & 2930.09 & 2878.99 & 2876.79 & 2870.90 \\
\hline$\ell_{1}$ & 0.61674 & 0.55019 & 0.51441 & 0.39128 & 0.60109 & 0.52254 & 0.51390 & 0.39027 & 0.62399 & 0.52567 & 0.51321 & 0.40130 \\
\hline$\ell_{2}$ & 0.33839 & 0.41207 & 0.44753 & 0.56808 & 0.24806 & 0.43905 & 0.44767 & 0.56917 & 0.24627 & 0.43598 & 0.44839 & 0.55837 \\
\hline$\ell$ & 0.95513 & 0.96225 & 0.96194 & 0.95936 & 0.84916 & 0.96158 & 0.96156 & 0.95943 & 0.87026 & 0.96165 & 0.96160 & 0.95966 \\
\hline$\alpha$ & 0.64385 & 0.56631 & 0.52899 & 0.40211 & 0.66940 & 0.53730 & 0.52836 & 0.40109 & 0.66407 & 0.54057 & 0.52767 & 0.41242 \\
\hline$\sigma$ & 3081.79 & 4551.79 & 4623.60 & 4343.50 & 1086.60 & 4616.82 & 4620.01 & 4343.26 & 1615.74 & 4585.67 & 4591.91 & 4350.38 \\
\hline
\end{tabular}

Table 40: Results for The Netherlands

\begin{tabular}{|c|c|c|c|c|c|c|c|c|c|c|c|c|}
\hline & \multicolumn{4}{|c|}{ Scenario Productivity Gap } & \multicolumn{4}{|c|}{ Scenario Profits } & \multicolumn{4}{|c|}{ Scenario Wages } \\
\hline & $\begin{array}{r}\text { Educated } \\
\text { Share }\end{array}$ & $\begin{array}{r}\text { Total } \\
\text { Employ. }\end{array}$ & $\begin{array}{r}\text { Social } \\
\text { Surplus }\end{array}$ & $\begin{array}{r}\text { Lisbon } \\
\text { target }\end{array}$ & $\begin{array}{r}\text { Educated } \\
\text { Share }\end{array}$ & $\begin{array}{r}\text { Total } \\
\text { Employ. }\end{array}$ & $\begin{array}{r}\text { Social } \\
\text { Surplus }\end{array}$ & $\begin{array}{r}\text { Lisbon } \\
\text { target }\end{array}$ & $\begin{array}{r}\text { Educated } \\
\text { Share }\end{array}$ & $\begin{array}{r}\text { Total } \\
\text { Employ. }\end{array}$ & $\begin{array}{r}\text { Social } \\
\text { Surplus }\end{array}$ & $\begin{array}{r}\text { Lisbon } \\
\text { target }\end{array}$ \\
\hline$t$ & 0.99900 & 0.38700 & 0.08500 & 0.08500 & 0.98900 & 0.40200 & 0.31600 & 0.34900 & 0.57700 & 0.03900 & 0.02300 & 0.02600 \\
\hline$w_{1}$ & 2106.58 & 3277.01 & 3857.22 & 3857.22 & 1102.42 & 3796.20 & 3819.39 & 3811.20 & 3830.20 & 3778.30 & 3777.14 & 3777.35 \\
\hline$w_{2}$ & 2043.25 & 2043.25 & 2043.25 & 2043.25 & 878.82 & 2063.38 & 2089.69 & 2080.35 & 1894.96 & 1875.34 & 1872.95 & 1873.40 \\
\hline$\ell_{1}$ & 0.47279 & 0.44419 & 0.39266 & 0.39266 & 0.47609 & 0.39952 & 0.38794 & 0.39254 & 0.48413 & 0.40611 & 0.38891 & 0.39290 \\
\hline$\ell_{2}$ & 0.48174 & 0.51291 & 0.56310 & 0.56310 & 0.31355 & 0.55677 & 0.56827 & 0.56371 & 0.36911 & 0.55010 & 0.56712 & 0.56320 \\
\hline$\ell$ & 0.95454 & 0.95710 & 0.95576 & 0.95576 & 0.78964 & 0.95629 & 0.95621 & 0.95626 & 0.85324 & 0.95620 & 0.95603 & 0.95610 \\
\hline$\alpha$ & 0.48676 & 0.45355 & 0.40008 & 0.40008 & 0.50860 & 0.40714 & 0.39532 & 0.40002 & 0.50207 & 0.41389 & 0.39629 & 0.40037 \\
\hline$\sigma$ & 2029.96 & 2561.06 & 2725.53 & 2725.53 & 810.68 & 2725.95 & 2730.26 & 2729.63 & 1191.09 & 2614.85 & 2625.86 & 2625.24 \\
\hline
\end{tabular}


Table 41: Results for Poland

\begin{tabular}{|c|c|c|c|c|c|c|c|c|c|c|c|c|}
\hline & \multicolumn{4}{|c|}{ Scenario Productivity Gap } & \multicolumn{4}{|c|}{ Scenario Profits } & \multicolumn{4}{|c|}{ Scenario Wages } \\
\hline & \begin{tabular}{|r} 
Educated \\
Share
\end{tabular} & $\begin{array}{r}\text { Total } \\
\text { Employ. }\end{array}$ & $\begin{array}{r}\text { Social } \\
\text { Surplus }\end{array}$ & $\begin{array}{r}\text { Lisbon } \\
\text { target }\end{array}$ & $\begin{array}{r}\text { Educated } \\
\text { Share }\end{array}$ & $\begin{array}{r}\text { Total } \\
\text { Employ. }\end{array}$ & $\begin{array}{r}\text { Social } \\
\text { Surplus }\end{array}$ & $\begin{array}{r}\text { Lisbon } \\
\text { target }\end{array}$ & \begin{tabular}{|} 
Educated \\
Share
\end{tabular} & $\begin{array}{r}\text { Total } \\
\text { Employ. }\end{array}$ & $\begin{array}{r}\text { Social } \\
\text { Surplus }\end{array}$ & $\begin{array}{r}\text { Lisbon } \\
\text { target }\end{array}$ \\
\hline$t$ & 0.99900 & 0.78900 & 0.11900 & & 0.97500 & 0.29400 & 0.13200 & 0.89800 & 0.82100 & 0.06400 & 0.01900 & 0.51100 \\
\hline$w_{1}$ & 784.61 & 868.26 & 1136.09 & & 242.47 & 1114.06 & 1130.47 & 715.41 & 1168.03 & 1127.34 & 1125.75 & 1146.37 \\
\hline$w_{2}$ & 714.33 & 714.33 & 714.33 & & 113.95 & 693.86 & 722.16 & 268.84 & 774.86 & 661.44 & 657.08 & 714.38 \\
\hline$\ell_{1}$ & 0.40296 & 0.39606 & 0.33443 & & 0.42142 & 0.35916 & 0.32939 & 0.43025 & 0.41809 & 0.36789 & 0.32985 & 0.42754 \\
\hline$\ell_{2}$ & 0.50216 & 0.50926 & 0.56655 & & 0.26837 & 0.54291 & 0.57156 & 0.41959 & 0.33243 & 0.53458 & 0.57095 & 0.44478 \\
\hline$\ell$ & 0.90512 & 0.90532 & 0.90098 & & 0.68979 & 0.90206 & 0.90095 & 0.84984 & 0.75052 & 0.90247 & 0.90080 & 0.87231 \\
\hline$\alpha$ & 0.42056 & 0.41238 & 0.34627 & & 0.46176 & 0.37201 & 0.34109 & 0.45009 & 0.46287 & 0.38127 & 0.34155 & 0.45003 \\
\hline$\sigma$ & 706.98 & 740.49 & 819.85 & & 139.28 & 811.17 & 820.54 & 439.78 & 150.69 & 781.85 & 799.05 & 434.39 \\
\hline
\end{tabular}

Table 42: Results for Portugal

\begin{tabular}{|c|c|c|c|c|c|c|c|c|c|c|c|c|}
\hline & \multicolumn{4}{|c|}{ Scenario Productivity Gap } & \multicolumn{4}{|c|}{ Scenario Profits } & \multicolumn{4}{|c|}{ Scenario Wages } \\
\hline & \begin{tabular}{|} 
Educated \\
Share
\end{tabular} & $\begin{array}{r}\text { Total } \\
\text { Employ. }\end{array}$ & $\begin{array}{r}\text { Social } \\
\text { Surplus }\end{array}$ & $\begin{array}{r}\text { Lisbon } \\
\text { target }\end{array}$ & $\begin{array}{r}\text { Educated } \\
\text { Share }\end{array}$ & $\begin{array}{r}\text { Total } \\
\text { Employ. }\end{array}$ & $\begin{array}{r}\text { Social } \\
\text { Surplus }\end{array}$ & $\begin{array}{r}\text { Lisbon } \\
\text { target }\end{array}$ & \begin{tabular}{|} 
Educated \\
Share
\end{tabular} & $\begin{array}{r}\text { Total } \\
\text { Employ. }\end{array}$ & $\begin{array}{r}\text { Social } \\
\text { Surplus }\end{array}$ & $\begin{array}{r}\text { Lisbon } \\
\text { target }\end{array}$ \\
\hline$t$ & 0.99900 & 0.29500 & 0.08700 & & 0.97400 & 0.17900 & 0.22100 & & 0.48400 & 0.01700 & 0.02200 & \\
\hline$w_{1}$ & 1170.61 & 2204.86 & 2513.71 & & 852.84 & 2525.36 & 2516.99 & & 2560.81 & 2511.13 & 2511.56 & \\
\hline$w_{2}$ & 1145.32 & 1145.32 & 1145.32 & & 604.78 & 1154.59 & 1148.92 & & 955.30 & 948.30 & 948.91 & \\
\hline$\ell_{1}$ & 0.26419 & 0.24853 & 0.22472 & & 0.26490 & 0.21765 & 0.22250 & & 0.27237 & 0.21734 & 0.22224 & \\
\hline$\ell_{2}$ & 0.62723 & 0.64944 & 0.67219 & & 0.39856 & 0.67941 & 0.67451 & & 0.46125 & 0.67950 & 0.67454 & \\
\hline$\ell$ & 0.89142 & 0.89797 & 0.89691 & & 0.66346 & 0.89707 & 0.89701 & & 0.73362 & 0.89683 & 0.89678 & \\
\hline$\alpha$ & 0.28585 & 0.26056 & 0.23466 & & 0.29753 & 0.22726 & 0.23233 & & 0.29188 & 0.22692 & 0.23208 & \\
\hline$\sigma$ & 1053.46 & 1322.71 & 1366.20 & & 474.09 & 1365.59 & 1366.46 & & 717.98 & 1333.57 & 1334.47 & \\
\hline
\end{tabular}


Table 43: Results for Sweden

\begin{tabular}{|c|c|c|c|c|c|c|c|c|c|c|c|c|}
\hline & \multicolumn{4}{|c|}{ Scenario Productivity Gap } & \multicolumn{4}{|c|}{ Scenario Profits } & \multicolumn{4}{|c|}{ Scenario Wages } \\
\hline & $\begin{array}{r}\text { Educated } \\
\text { Share }\end{array}$ & $\begin{array}{r}\text { Total } \\
\text { Employ. }\end{array}$ & $\begin{array}{r}\text { So } \\
\text { Surp }\end{array}$ & $\begin{array}{r}\text { Lisbon } \\
\text { target }\end{array}$ & $\begin{array}{r}\text { Educated } \\
\text { Share }\end{array}$ & $\begin{array}{r}\text { To } \\
\text { Empl }\end{array}$ & $\begin{array}{r}\text { So } \\
\text { Sur }\end{array}$ & $\begin{array}{r}\text { Lis } \\
\text { tal }\end{array}$ & $\begin{array}{r}\text { Educated } \\
\text { Share }\end{array}$ & $\begin{array}{r}\text { Total } \\
\text { Employ. }\end{array}$ & $\begin{array}{r}\text { Sc } \\
\text { Sur }\end{array}$ & $\begin{array}{l}\text { Lisbon } \\
\text { target }\end{array}$ \\
\hline$t$ & 9900 & & & & & & & & & & & \\
\hline$w_{1}$ & 2531.81 & 2621.57 & 3184.21 & 320 & & 3028.17 & 3074.93 & & & 301 & & .63 \\
\hline$w_{2}$ & 2355.63 & 2355.63 & 2355.63 & 235 & 75 & 2388.13 & 2482.04 & 247 & 23 & 226 & 22 & 225 \\
\hline$\ell_{1}$ & 17399 & 0.46978 & 0.39923 & 0.38 & 40 & 0.43 & 0.38 & 0. & 35 & 0.48 & 0.3 & 641 \\
\hline$\ell_{2}$ & 0.44148 & 0.44574 & 0.51133 & 0.52183 & 0.23212 & 0.48370 & 0.52765 & 0.5 & 0.28085 & 0.47571 & 0.52226 & 0.52502 \\
\hline$\ell$ & 0.91547 & 0.91553 & 0.91056 & 0.90945 & 0.72452 & 0.91407 & 0.91205 & 0.9 & 7620 & 0.91391 & 0.91165 & 0.91143 \\
\hline$\alpha$ & 0.49256 & 0.48766 & 0.41227 & 0.40020 & 92 & 0.44497 & 0.39729 & 0.4 & 09 & 0.4 & 0.4 & 0.39920 \\
\hline$\sigma$ & 2327.19 & 2369.91 & 2572.39 & 2570.36 & 8.43 & 2553.33 & 2592.10 & 2592.02 & 996.45 & 2406.34 & 2459.74 & 2459.69 \\
\hline
\end{tabular}

Table 44: Results for Slovakia

\begin{tabular}{|c|c|c|c|c|c|c|c|c|c|c|c|c|}
\hline & \multicolumn{4}{|c|}{ Scenario Productivity Gap } & \multicolumn{4}{|c|}{ Scenario Profits } & \multicolumn{4}{|c|}{ Scenario Wages } \\
\hline & $\begin{array}{r}\text { Educated } \\
\text { Share }\end{array}$ & $\begin{array}{r}\text { Total } \\
\text { Employ. }\end{array}$ & $\begin{array}{r}\text { Social } \\
\text { Surplus }\end{array}$ & $\begin{array}{r}\text { Lisbon } \\
\text { target }\end{array}$ & $\begin{array}{r}\text { Educated } \\
\text { Share }\end{array}$ & $\begin{array}{r}\text { Total } \\
\text { Employ. }\end{array}$ & $\begin{array}{r}\text { Social } \\
\text { Surplus }\end{array}$ & $\begin{array}{r}\text { Lisbon } \\
\text { target }\end{array}$ & $\begin{array}{r}\text { Educated } \\
\text { Share }\end{array}$ & $\begin{array}{r}\text { Total } \\
\text { Employ. }\end{array}$ & $\begin{array}{r}\text { Social } \\
\text { Surplus }\end{array}$ & $\begin{array}{r}\text { Lisbon } \\
\text { target }\end{array}$ \\
\hline$t$ & 0.99900 & 0.58900 & 0.10800 & & 0.95600 & 0.14700 & 0.09200 & & 0.81500 & 0.03600 & 0.02000 & \\
\hline$w_{1}$ & 715.91 & 949.08 & 1224.56 & & 317.92 & 1207.98 & 1214.67 & & 1271.56 & 1210.89 & 1210.05 & \\
\hline$w_{2}$ & 644.96 & 644.96 & 644.96 & & 114.83 & 641.90 & 650.71 & & 698.08 & 544.79 & 542.72 & \\
\hline$\ell_{1}$ & 0.24774 & 0.23950 & 0.20680 & & 0.25960 & 0.21374 & 0.20414 & & 0.25434 & 0.21587 & 0.20478 & \\
\hline$\ell_{2}$ & 0.61144 & 0.62062 & 0.65050 & & 0.36342 & 0.64407 & 0.65341 & & 0.41339 & 0.64182 & 0.65255 & \\
\hline$\ell$ & 0.85918 & 0.86013 & 0.85730 & & 0.62301 & 0.85782 & 0.85754 & & 0.66772 & 0.85769 & 0.85733 & \\
\hline$\alpha$ & 0.26365 & 0.25259 & 0.21660 & & 0.28730 & 0.22395 & 0.21386 & & 0.28760 & 0.22623 & 0.21452 & \\
\hline$\sigma$ & 614.23 & 671.83 & 718.62 & & 134.19 & 717.26 & 719.16 & & 143.41 & 698.11 & 701.01 & \\
\hline
\end{tabular}




\section{A.5 Graphical analysis}

The two following graphics represent the gap between the situation in 2010 and the objective considered. Distances are presented in percentage point. The ordinates represent the gap in the educated share $\alpha$, and the axis represent the gap in the tax rate. Graph 1 gives the measure for the Productivity Gap scenario, and Graph 2 gives the measure for the Profits scenario. 
Figure 1: Gap between 2010 and the objective, scenario PG

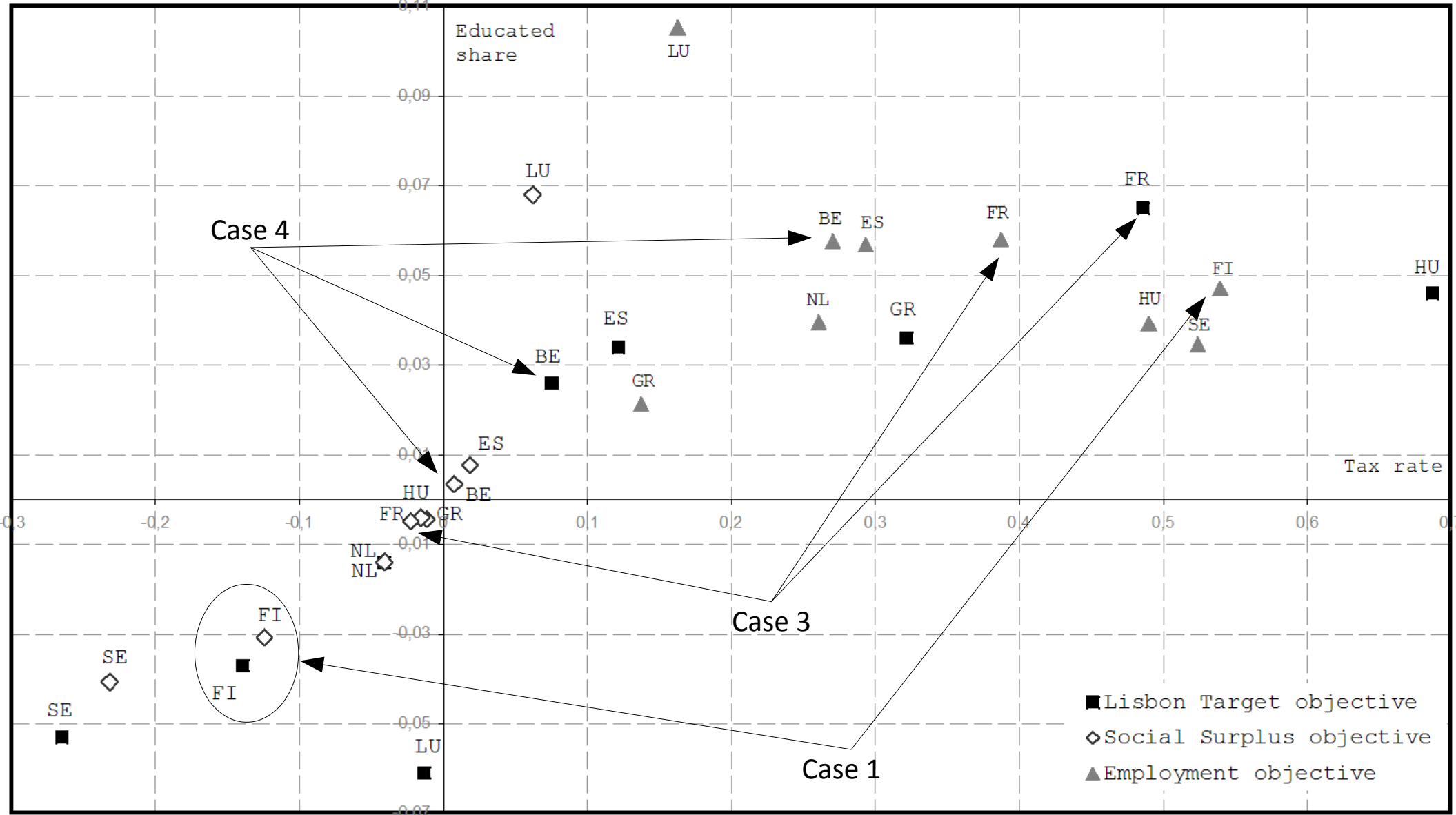


Figure 2: Gap between 2010 and the objective, scenario P

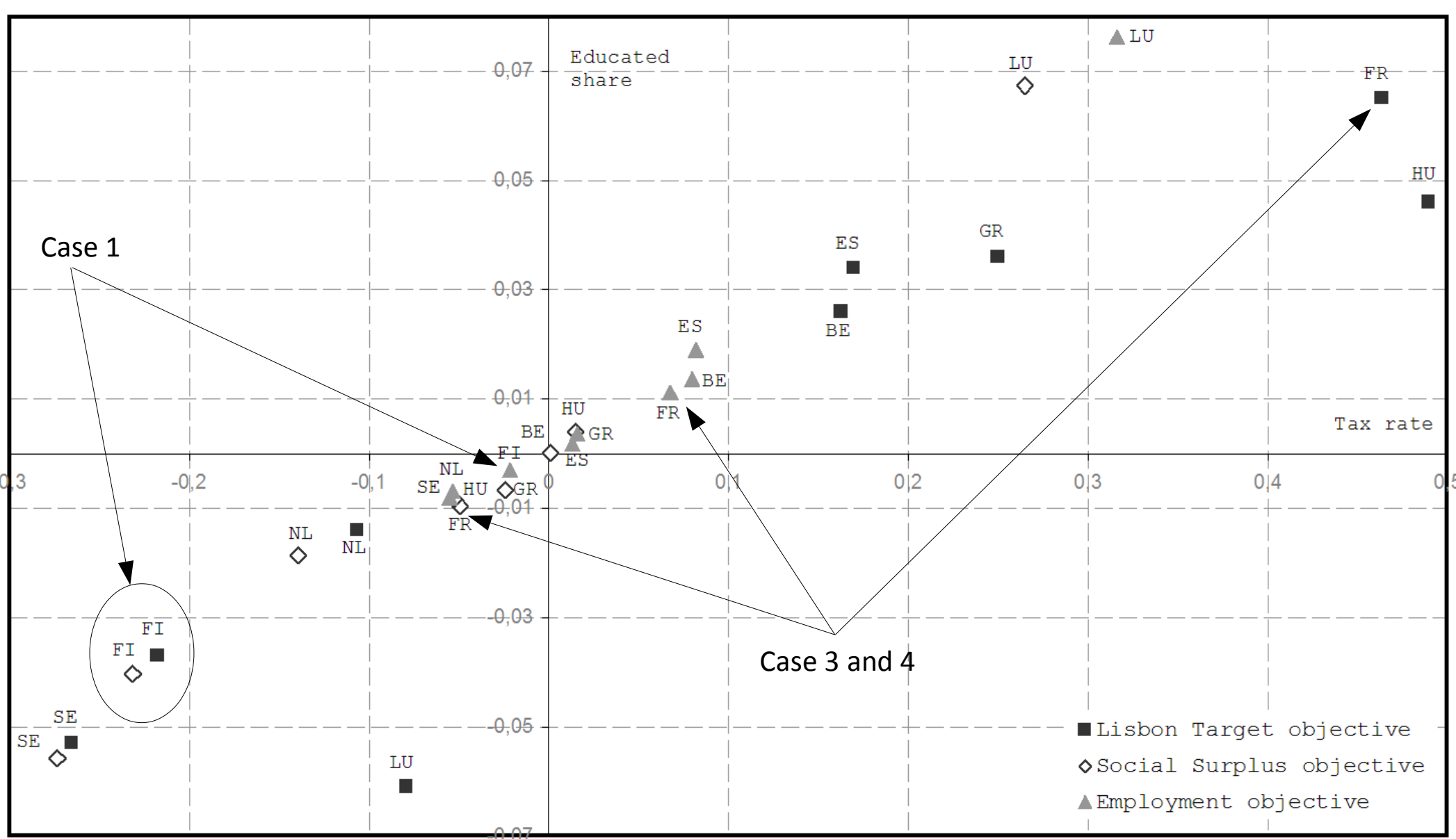

